\title{
耳鼻咽喉科領域二於ヶルフックス氏 反應各型，臨林的意義
}

\author{
Tr. Rokuro LIiraoka : Klinische Bedeutung der \\ Reaktionstypen bei $\mathrm{Ca}-\mathrm{R}$ nach Fuchs.

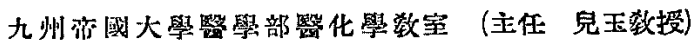

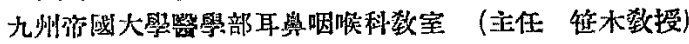 \\ 大學院學坐 平 岡 六 毁 \\ 目次

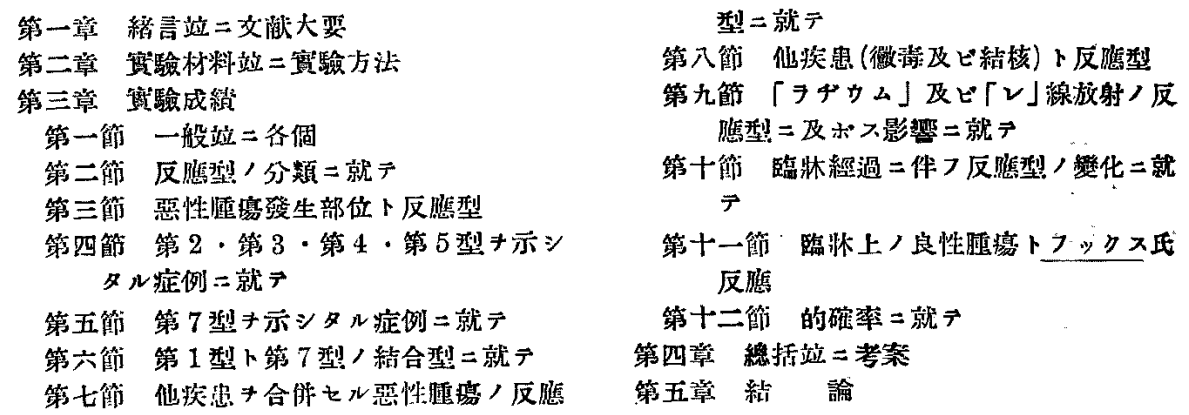

\section{第 一 草}

緒言並二文献大要

人澧二癌朠聯生七バ其血液成分 $=$ 物理的並 $=$ 化學的變化 7 薊起スルコト八. 血清蛋白沈泟現 象，變化．溶血作用．赤吹球沈绦速度，變化等

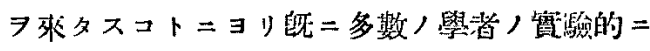

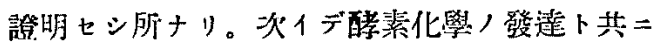

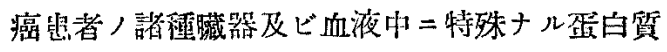
分僻酵素，發現スルコトモ次第二䦕明セラル、 ニ至レリ。

1908年フィ.シャ一 Fischer H. 八癌息怒，胃 液中二特殊ナル蛋白質分解酵装/H現スルラ發
見シ 其酵菜八蛋白質分解=際シ「アルブモー ゼ」二止マラズシテ.「アミ，酸二迄分解シ得 ル能力ラ有スル怊二於テ「ペプシン」ト異ルトナ シ. 次イデ 1909 年ノイバウエル及フイッシャ - Neubauer O. u. Fischer H. 八癌患者/胃 液中二八極メテ强力ナル「ペプトン」分解醋素 存在スルモ，健康人筲液中二八存七ズ．該酳素

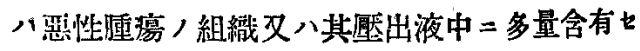
ラル、事ヨ知リ。其「デベプチード」执水分解作 用アルヨ癌診斷二應用シ得ベシト說キタリ。更 
二腄晹ヨリ分泌セラル、異常ナル酵素二就キテ ハァプデルハルデン Abderhalden E. 及ビ其

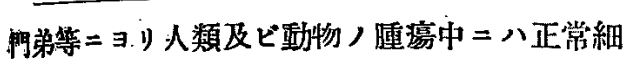
胞丵素ニ比シテ「ボリペプチード」及ビ「ペプ トン」ヨ速二分解スル酵素存在シ，其分解这物 モ全り正常細酵素ノ夫レト異ルモノナルラ確 浔セラレタリ。

1910年フロインド及ビカるーネル Freund E. u. G. Kaminer 八血清學的見地 $コ$ 㬎微鏡上 =於テ，癌患者血清八癌細胞习破壞セザルモ正 常人血清八癌細胞习破塙スル事實 7 發見シ。之

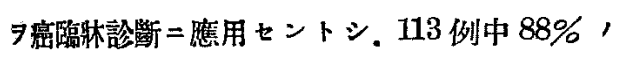
陧性成績 7 得タルモ。党二新焦ナル漓細胞 7 研 究室二保存スル事八困難ナルア以テ、一般ノ推 獎习得ルニ至ラザリキ。

同年ノイベルグ Neuberg C. 八癌絧胞卜正裳 血清トヨ混合消化セシメタルモ, 、殘餘空素量 八增加スレドモ。癌細胞卜癌血清卜ヨ混合七シ タタルモノ、殘餘突素量ハ增加セズトノ所見 得々り。

抑々血清ノ蛋白質分解作用二就テハ橧多，學者 二低り研究諭守セラレタル所ニシテ．現今其作 用八碓認七ラレタル事實ナルモ。他方アル保件

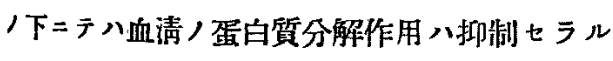

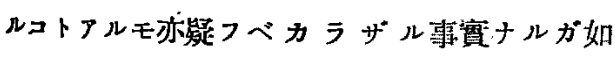

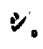

1914年アプデルハルデンハ婎婦，血清=胎鳌蛋 白习添加作用セシメテ。該蛋白ノ分解セラル、 ７見，健康䐺，血清中=八蛋白翼分解酵素ナキ

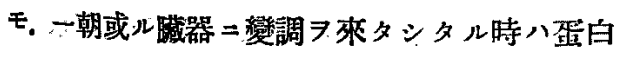

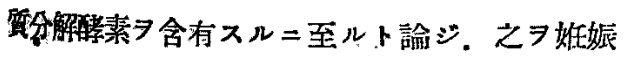
喰㩰二應用七り。

1921年ステフェン及ゥะール Stephan R. u. E.
Wobl ハ「カルiンフィプリン」フ用ヒテ.

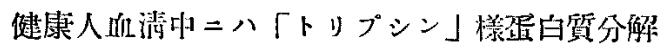
酵素ノ存在习監䜅セり。

1926年フックス Fuchs H.J. 八以上ノ諸家ノ研

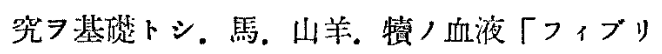
ン」ヨ作リ太等，县物，血清ト「フィブリン」 トヨ作用セシメテ．アブデルハルデンノ透析法 フ應用シ。自己，改良七ルバンダ Bang /「i クロキールダール」法ヨ用ヒテ 悡緟「フィブ

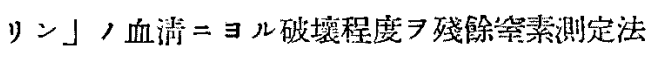

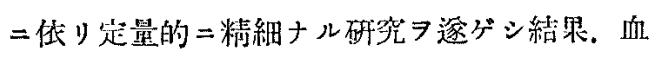
街ハ自己卜同種族，「フィブリン」ア破壇せザ ルモ。他種族ノ「フィブッン」フ破瓄スト，事

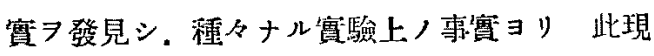
象八酵素 $=$ ル分解作用二基クモ，ト考へタ 1。

更二フックスハァブデルハルデン，呼笲二依ル

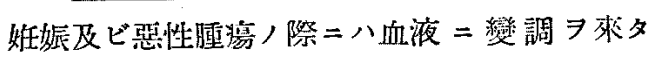
シ 血清ハ自己卜其性買 7 異ニスル蛋白郍

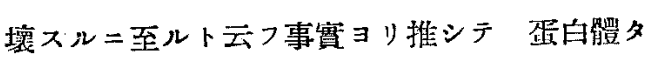
ル「フンブリン」モ。異常狀態ノ血清ヨリ分解

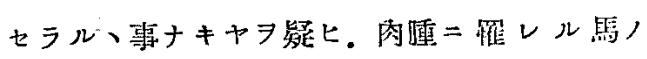
「フィブリン」ト血清トラ用ヒテ檢シタルニ 肉腫馬血清八闪属琵「フィブリン」ア破壤せザ ルモ。健康馬「フィブリン」フ破壤スル事認

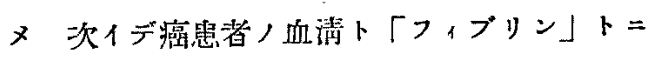
就テモ同樣ナル事實ヨ確認スルニ至レリ。倘ホ フックスハ多数，疾病二就キ詳組ナル研究 $\ni ナ$ シ.

（1）正常人血清八正常「フィプリン」习破 壦セザルモ。病的「フィブリン」ヨ破壇ス。

(2) 病的血清八同種/病的「フィプリン」 フ破壦七ザルモ。正常「フィブリン」习破 
壤スルニ歨:ラズ。他種疾病「「ィブリ

ン」ヨモ破壤スル。

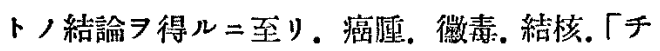
フス」. 猩紅熱等, 鑑別診斷=成功セリ。

其後フックスハ筫驗方法二種々，改良习师一。

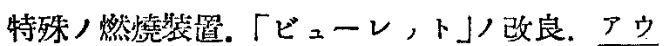
テンリート式比色計 7 改良七从前後二重「カ1 ル」ヨリ成几精密比色計ノ考案等 績ノ正確ア期シ 絕エザル努力ラ續ケタリ。 其後つナルタン八ウゼン・キャドネス及ウャル ㄱ. デブリン: 吕メのカ及ヨ゙・トレーべ. シャテンヘルム. カスパリ. ビング. コワルチ 1ク・妇・ルッェウスキ一・ ブランド- ジェ

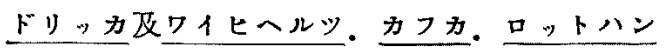
マー及ローゼンボーム、ピストフィデ、ス等二 依リ追試セラレタリ。

我國二於テ八昭和 8 年(1933)フックスト共二共 同研究サレシ引地氏ニヨリ初メテ紹介セラレタ ルモノニテ 同年兒玉㸚授八殘硢營絜测定法= ヴ・ンスライクノ法习應用シ該反應检查.上ニ一 大利便

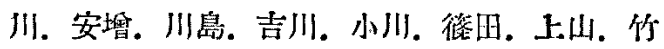
內等ニ依り追試サレ良好ナル結果 $フ$ 得タリ。 次二反應型二關シテハ 1926 年フっクス及フォ ルケンハウゼン M. V. Falkenhausen 八定型 的ナル陽性並二陰性反虑型以外 $=$ ，癌並 $=$ 正常

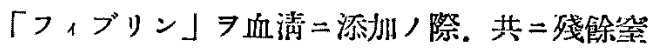
素ノ娍少ラ來タスモノアル二注意シ。此現嗳八 恰毛毒素卜抗毒素ト 7 混合七儿場合，殘馀案素 減少二該賞スルトナシ 抗酵素多量二存在シ。

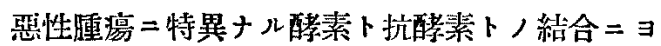
リ大分子，蛋白トナリ 三監化醋酸二訨り沈澱 スル篇ナリト說明セり。該反憵习呈セルモノ八

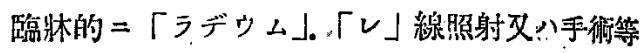
ニ依リ經過良好ナルモノ二認メ，該反應型习所 謂「苼度反應」ト名ヅケタリ。其後此所謂「營 疫反應」型ハフックス及ビ其他ノ諸學者三偖》。

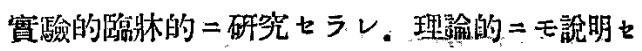
ラル、ニ至レリ。

1931 年キャドネス及ウャルフ Cadness B.H. E. u. C.G.L. Wolf ハ「ラヂウム」敖法ノフォ クス氏区應二及ボス影響习检シ，直腸癌ノ一患 著二「ラデゥム」フ放射セル後 3 時間 =シテ血清 ，琶白質分解作用八全ク停止シ. 20 日後二モ岗 ホ談作用ノ帍ラザルフ經驗セり。次イデ 1932年

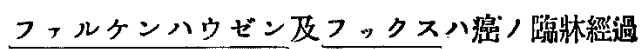
ニ伴フコックス氏反應/變化ヨ研究シ。「レ線 「ラヂウム」手術等ノ影響习檢㫜セシガ. 其經 過中正常「フィブリン」並=癌「フィブリン」 添加ノ際. 两者共其殘俆学素量分血清ノi/場 合二比シ殆ンド差习認メザル反應型ヨ示スヨ 見.（土).？又八 indifferent $ナ$ 記號习用七 タルモ. 其反應型ノ意菜ニ就キテハ何等言及七 ザリキ .

其後 1933 年兒玉敎授八之等反應型 76 型二分 チテ說明シ。次イデ長谷川ハ之ヨ 10 型二分チ テ理論的說明 フ試ミ。ファルケンハウゼン及ビ

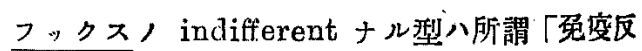
憵」型ノ前挠二出現スルトナシ. 之ヨ移行型卜 名附ヶタリ。最近安垍ハ 7 型二分類シ反應型卜 豫後ト二就キテ述ベタリ

又澏ニシテフックス氏反應㓌性ヨ示スモノ八極 メテ稀ナルモ食道癌二於テハ屡る院性タ示スコ トアルハ 1926 年既二フっクスニヨリテ注意セ ラレ. 其後ニ於テモブランド Brandt(1935). ジェドリッカ及ワイヒハルッ Jedlick V. u. 
E. Weichlerz(1935) 等 $=$ ヨ總驗セラレタル 所ナり。

又、熩ニ非ズシテフックス氏反隹隄性ナルモ， モ。諸家ニ侬少屡 、注意七ラレタル所ニシテ、 㴔石症，胃及ビ十二指腸潰瘍。慢性胃炎。婎娠 等二屡飞見ルモノニシテ，フックスハ之等疾病 二於ケル陽性反應出現八解釋=就 +1935 年\%, クルッェウスキーZ Zakraewski ト共二詳細ナ 几記述アナシ之等五理諭的二說明スル所アリタ リ。

余八昭和 10 年 (1935) 以來笹木数授亚=兒玉教 授指尊ノ下=，九大耳鼻咽喉科學敉室二於テ惡 性腫場ノ疑ヒアル外來並二入院患者二就キフッ クス氏反應习追試シ. 臨牀經過二件フ反應ノ變 化习観察シ. 殊=「ラデウム」療法並二手術操 作／該区虑二及ボス影響。食道癌卜該反應，閲

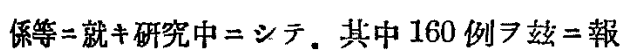
告諸家/批制フ仰がントスルモノナリ。

\section{第二草}

\section{實驗材料並二實醶方法}

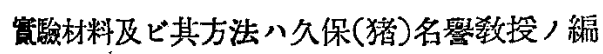
算=ナル日本耳宜咽㩔科全書第 1 卷， $4=$ 兒玉

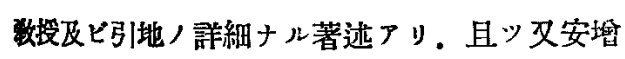
八福岡醫科大學雜誌第 30 卷第 2 號二氏，改良 せル算等二就キ記述セルラ以テ，重䙉フ避ケテ 其骨子ノ ヨ㥛メラ簡單二摘錄スルニ止メン。 血清材料八主トシテ儿州帝國大學醫學部耳鼻咽 峥科数室外來患者及ヒ大入院患者 =シテ，惡性腫 落及ビ其疑ヒアル患者ヨリ探血シテ 其血清 分堆シ. 之ョ先ッ゙正碓 $=1.0 \mathrm{ec}$ 第 1 ，內容約 15.0

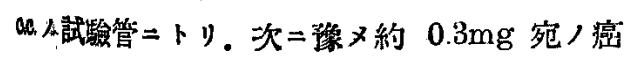
「フィプリン」並=正常「フィプリン」习容レ 11-31
タル第 2 第 3 人試驗管二夫タ 1.00 .0 . ヅ、加へテ 血清ト「フィブリン」米良ク混和セシメタル 後.「クロロホルム嘹氮习充シタル「エキシカ ートル」中二樹立シ之 7 密閉シテ. $38-41^{\circ} \mathrm{C}$ ， 睬率器二移シ 8 時間以上24時間消化セシメタル 後. そヨ取出シテ各管 $=3.5 \%$ 三眮化醌酸 11.0 c.c. $\ni$ 加へラ高級蛋白 $\ni$ 沈測セシメ. 其浪液各 8.0

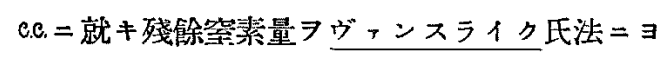
リ比色定量シテ．癌「フィブリン」立业二正常 「フィブリン」添扣, 際ノ殘餘空素量习血清, ¿ /場合ノ夫レト比較對照シテ「フィブリン」 ，破壤程度习定メタリ。

此際特=注意セルハ「フィブリン」基質ニシデ 癌「フィプリン」並二正常「フィブリン」共二 良クえヨ精製シ. 特二其水洗习充分ニナシ. 數 回正常並二癌血郝 $习$ 用ヒテ其破壞サル、程度

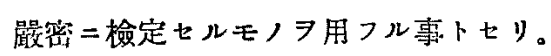

\section{第 三章}

實 㗊 成 續

$$
\text { 芽一箅 一般並二各㑑 }
$$

各症例ニ就キテハ詳細ナル記述习避年. 主卜 シテ㓻照タル血清及ビ癌「フィブリン」並二正 常「フィブッン」添加，際ノ殘解空素量测定值. 反應型．面二簡單ナル臨林上，諧要項即于病 歷。病理組織的所見.「レ線學的所見. 手術.

「ラヂゥム」「「レ」線深部治療等 $=ヨ ル$ 治療成 績. 經過等二就キ表示スレバ第 1 裴ノ如シ。 


\begin{tabular}{|c|c|c|c|c|c|c|c|c|c|c|c|c|c|c|c|c|c|}
\hline 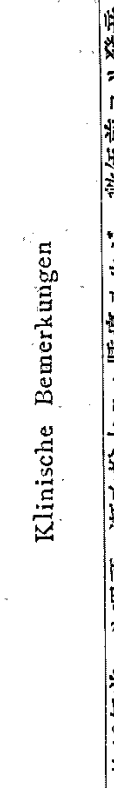 & 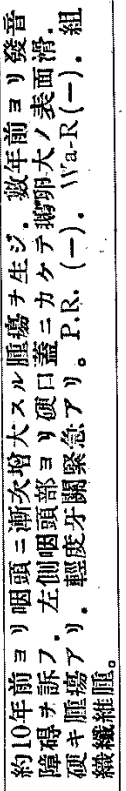 & 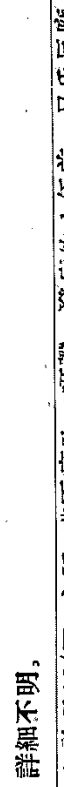 & 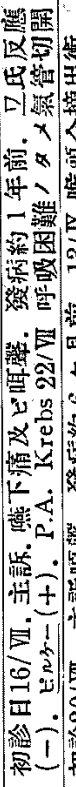 & 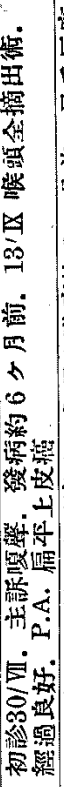 & 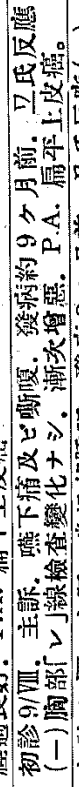 & 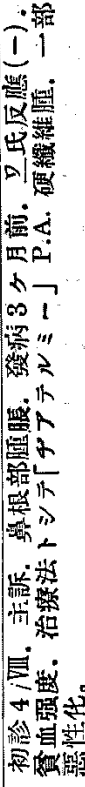 & 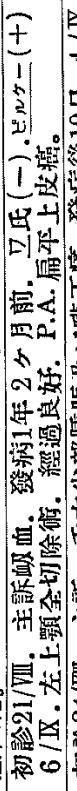 & 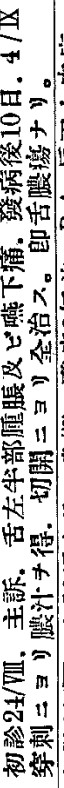 & 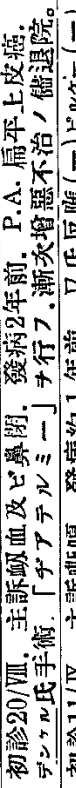 & 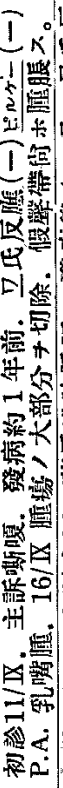 & 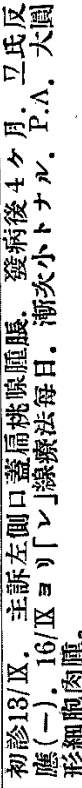 & 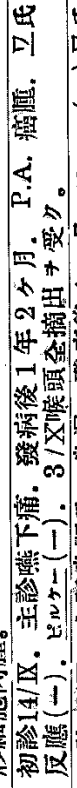 & 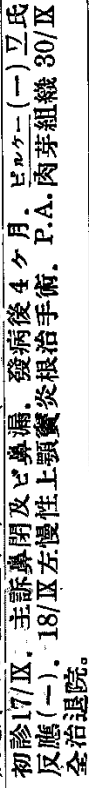 & 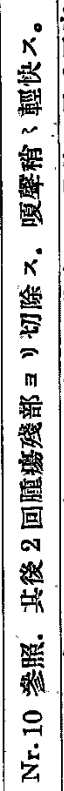 & 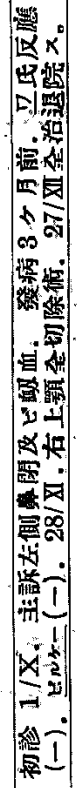 & 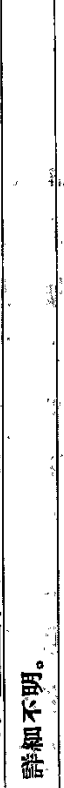 & 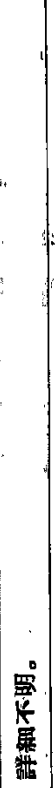 \\
\hline 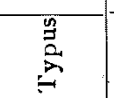 & $\varpi$ & 白 & $\mapsto$ & 目 & $\mapsto$ & 目 & $\begin{array}{l}E \\
+ \\
+\end{array}$ & $\mapsto$ & $\mapsto$ & $\begin{array}{l}\text { E } \\
+ \\
+\end{array}$ & $\mapsto$ & 曰 & $\mapsto$ & 目 & Ш & 目 & 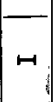 \\
\hline 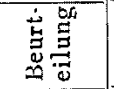 & + & + & $t$ & $t$ & + & $t$ & + & + & + & + & + & $t$ & + & + & + & 1 & + \\
\hline 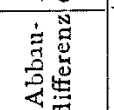 & 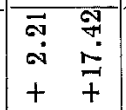 & 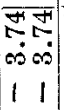 & 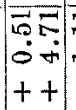 & \begin{tabular}{cc}
$\vec{Z}$ & $\overline{1}$ \\
\hdashline & 0 \\
1 & 1 \\
1 & 1
\end{tabular} & 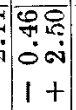 & 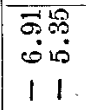 & 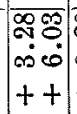 & 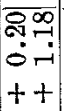 & 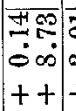 & 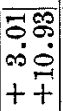 & $\begin{array}{l}\mathscr{8} \\
0 \\
0+4 \\
++\end{array}$ & $\mid \begin{array}{cc}0 & 0 \\
0 & 0 \\
0 & 0 \\
1 & 7 \\
1 & 7\end{array}$ & 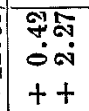 & 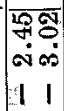 & 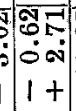 & $\begin{array}{l}90 \\
9\end{array}$ & 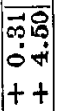 \\
\hline $\mid \begin{array}{c}z \\
+\end{array}$ & $\begin{array}{l}80 \\
\text { से }\end{array}$ & \begin{tabular}{l} 
\\
\multirow{4}{*}{} \\
$\stackrel{9}{S}$
\end{tabular} & 굼 & $\begin{array}{l}\vec{t} \\
\dot{\infty} \\
\infty\end{array}$ & $\begin{array}{l}\infty \\
\infty \\
0 \\
0 \\
\infty\end{array}$ & 官 & $\begin{array}{l}5 \\
5 \\
0\end{array}$ & \begin{tabular}{|l|}
$\underline{6}$ \\
$\dot{0}$ \\
$\dot{0}$
\end{tabular} & 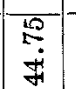 & 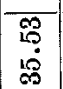 & 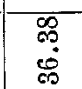 & $\begin{array}{l}0 \\
\dot{9} \\
\dot{q}\end{array}$ & 㞼 & $\underset{\sim}{\infty}$ & $\begin{array}{l}0 \\
\\
10 \\
0 \\
6\end{array}$ & $\begin{array}{l}\text { 울 } \\
\stackrel{\circ}{\circ}\end{array}$ & 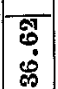 \\
\hline 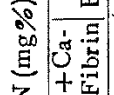 & $\begin{array}{l}8 \\
0 \\
8 \\
8\end{array}$ & 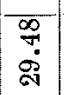 & $\begin{array}{l}\bar{b} \\
\infty \\
\infty\end{array}$ & $\begin{array}{l}\overrightarrow{1} \\
\dot{m} \\
\dot{m}\end{array}$ & $\begin{array}{l}50 \\
0 \\
0\end{array}$ & की & $\begin{array}{l}\stackrel{9}{0} \\
\stackrel{\infty}{\infty}\end{array}$ & $\begin{array}{l}\overline{\mathscr{B}} \\
\stackrel{6}{8} \\
\text { gi }\end{array}$ & $\begin{array}{l}\text { भి } \\
\text { ๓ं }\end{array}$ & $\begin{array}{l}\overline{0} \\
\dot{5}\end{array}$ & 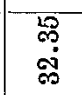 & 苛 & เู่ & $\begin{array}{l}8 \\
\infty \\
\infty\end{array}$ & 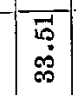 & $\begin{array}{l}\ddot{g} \\
\dot{\phi} \\
\dot{m}\end{array}$ & बैं \\
\hline 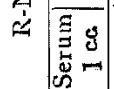 & $\begin{array}{l}\infty \\
\infty \\
0 \\
0\end{array}$ & $\mid \begin{array}{c}\mathbb{N} \\
\mathbb{\infty} \\
\tilde{\infty}\end{array}$ & $\begin{array}{l}8 \\
\dot{\infty} \\
\infty\end{array}$ & $\vec{\square}$ & $\begin{array}{l}\frac{m}{2} \\
\vec{c} \\
0\end{array}$ & 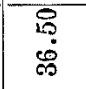 & $\begin{array}{l}5 \\
\infty \\
\infty\end{array}$ & 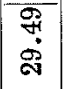 & $\begin{array}{l}\text { के } \\
\text { के }\end{array}$ & $\begin{array}{l}0 \\
\dot{B} \\
\dot{0}\end{array}$ & $\begin{array}{l}\frac{\mathscr{S}}{\ddot{m}} \\
\dot{m}\end{array}$ & $\begin{array}{l}\frac{52}{7} \\
\frac{7}{60}\end{array}$ & 造 & 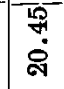 & 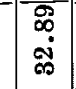 & 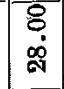 & స్. \\
\hline 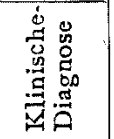 & 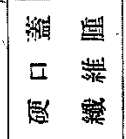 & 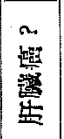 & 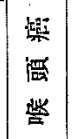 & 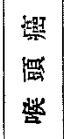 & 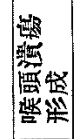 & 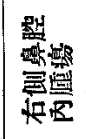 & 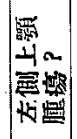 & 初 & 覀 & 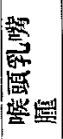 & 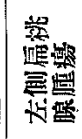 & 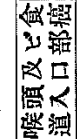 & 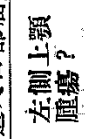 & 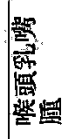 & 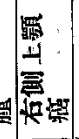 & 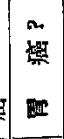 & 豎 \\
\hline 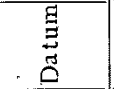 & 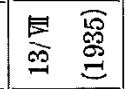 & 是 & 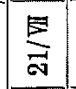 & \begin{tabular}{l} 
圅 \\
\multirow{2}{*}{}
\end{tabular} & $\underset{\mathscr{m}}{\text { 罚 }}$ & 悬 & 㑊 & 具 & $\frac{\Delta}{5}$ & $\stackrel{\Xi}{\Xi}$ & $\stackrel{\Delta}{\alpha}$ & $\stackrel{\Delta}{0}$ & $\frac{\sqrt{4}}{\sqrt{a}}$ & 商 & $\underset{-1}{\otimes}$ & $\frac{x}{a}$ & $\frac{\dot{x}}{N}$ \\
\hline 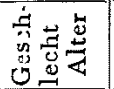 & so 㝒 & $\begin{array}{l} \\
\text { 敄 } \\
k\end{array}$ & <० & to: & to & of & to: & to: & to & < & \& & <i. & < & 过 & 它 & so & to \\
\hline $\begin{array}{l}\frac{0}{1} \\
\frac{3}{4}\end{array}$ & $\begin{array}{l}\text { 蓉 } \\
0 \\
\dot{*}\end{array}$ & $\begin{array}{l}\text { 辣 } \\
\equiv \\
\Xi\end{array}$ & 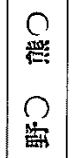 & \begin{tabular}{l}
0 \\
$+\alpha$ \\
0 \\
\multirow{2}{*}{}
\end{tabular} & 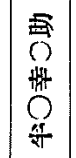 & $\begin{array}{l}O^{4} \\
\stackrel{H}{O} \\
\text { E }\end{array}$ & $\begin{array}{l}\text { 诰 } \\
0\end{array}$ & 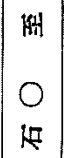 & 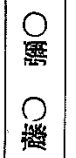 & $\begin{array}{l}0 \\
1 \\
0 \\
R\end{array}$ & 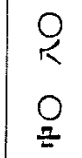 & 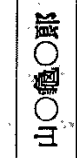 & 0 & $\begin{array}{l}0 \\
1 \\
0 \\
x\end{array}$ & 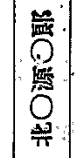 & 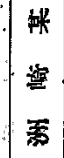 & $\begin{array}{l}\text { 䗇 } \\
+ \\
*\end{array}$ \\
\hline$\dot{\vec{z}}$ & -1 & ov & - & 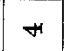 & 10 & 0 & $N$ & $\infty$ & os & O & $\exists$ & 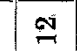 & 9 & $\ddot{H}$ & 19 & $\stackrel{\oplus}{\sim}$ & -1 \\
\hline
\end{tabular}




\begin{tabular}{|c|c|c|c|c|c|c|c|c|c|c|c|c|c|c|c|c|c|c|}
\hline 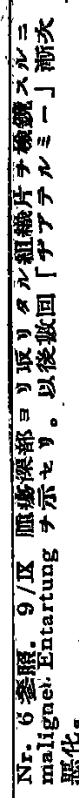 & 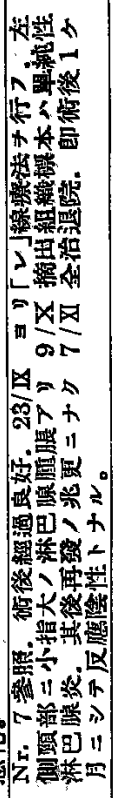 & $\mid \begin{array}{c}\text { 震 } \\
\text { 暴 } \\
\text { 视 }\end{array}$ & 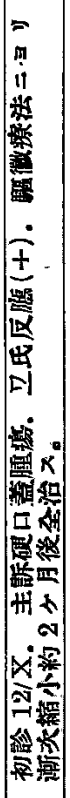 & 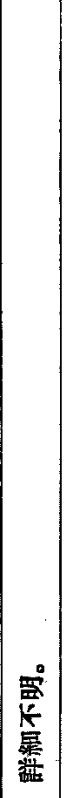 & 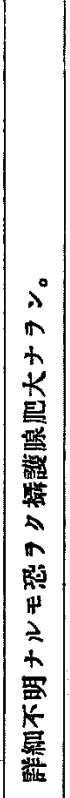 & 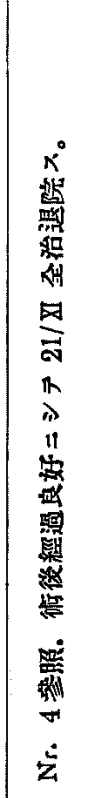 & 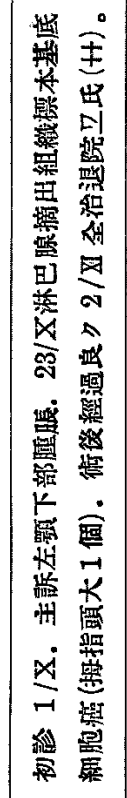 & 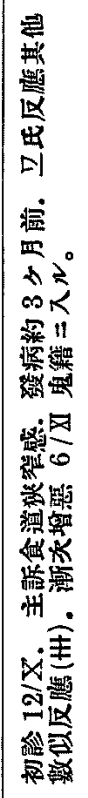 & 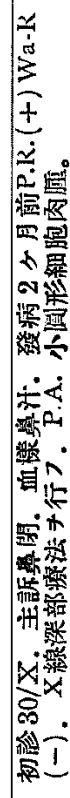 & 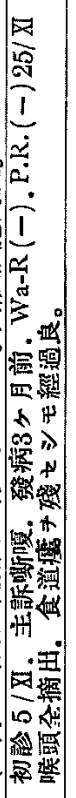 & 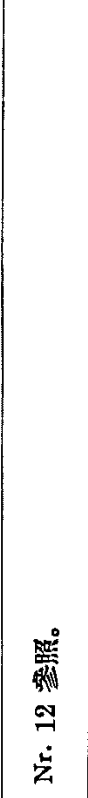 & 長 & 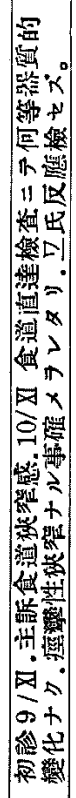 & 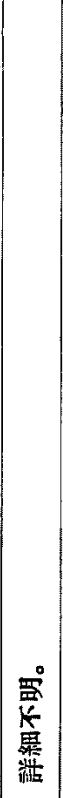 & $\begin{array}{c}\text { 誉 } \\
\text { 籚 } \\
\end{array}$ & 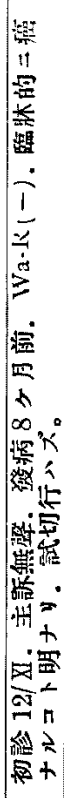 & 裳 & 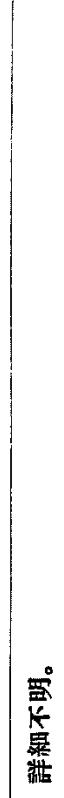 \\
\hline$H$ & 目 & $\rightarrow$ & $\Delta$ & $\nexists$ & 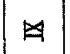 & 罗 & 年 & $\mapsto$ & 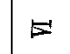 & $n$ & E & 콜 & 目 & $F$ & 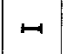 & $\mapsto$ & $\nexists$ & -1 \\
\hline+ & $\cdots 1$ & + & 1 & + & 1 & 1 & 1 & + & + & + & $t$ & 1 & 1 & + & + & + & + & + \\
\hline 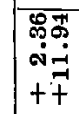 & $\begin{array}{l}\text { 육ㄱㄱ } \\
100 \\
++\end{array}$ & 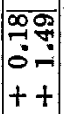 & 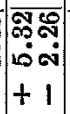 & $\begin{array}{ll}5 & 0 \\
\infty & 0 \\
0 & 0 \\
1 & 1\end{array}$ & 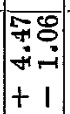 & $\begin{array}{l}\text { क유 } \\
-i 0 \\
++\end{array}$ & 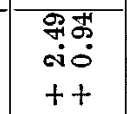 & 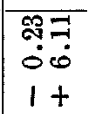 & 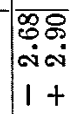 & $\begin{array}{c}\infty \\
\infty \\
-\infty \\
-\infty \\
++\end{array}$ & 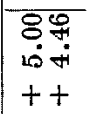 & 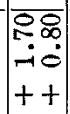 & 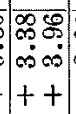 & 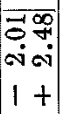 & 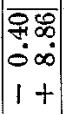 & 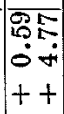 & $\begin{array}{l}0.0 \\
00 \\
00 \\
11\end{array}$ & 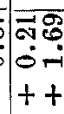 \\
\hline 웅 & 告 & \begin{tabular}{|l|}
\multirow{2}{*}{} \\
\multirow{2}{*}{}
\end{tabular} & 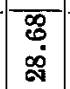 & $\begin{array}{l} \\
\dot{m} \\
\dot{\infty}\end{array}$ & \begin{tabular}{l} 
कू \\
\multirow{2}{*}{} \\
\multirow{a}{*}{}
\end{tabular} & $\begin{array}{l}\bar{\infty} \\
\dot{\infty} \\
\stackrel{i}{\mid}\end{array}$ & $\begin{array}{l}\overrightarrow{0} \\
\infty \\
\infty\end{array}$ & 羿 & $\begin{array}{l}8 \\
8 \\
\infty\end{array}$ & 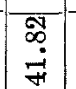 & $\begin{array}{l}\text { \%్ণ } \\
\text { ๙ิ }\end{array}$ & $\begin{array}{l}\text { จิ } \\
\text { เุ่ }\end{array}$ & $\begin{array}{l}\text { \& } \\
\text { มิ }\end{array}$ & $\mid$ & $\begin{array}{l}\overrightarrow{0} \\
\infty \\
\infty \\
q\end{array}$ & 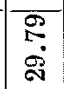 & $\overrightarrow{5}$ & 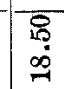 \\
\hline $\begin{array}{l}\infty \\
\stackrel{0}{\circ} \\
\text { gु }\end{array}$ & $\begin{array}{l}\text { ֻू } \\
\text { มี } \\
\text { มे }\end{array}$ & $\begin{array}{l}\text { बू. } \\
\text { ลุ่ }\end{array}$ & $\begin{array}{l}\mathscr{q} \\
\stackrel{8}{\circ}\end{array}$ & 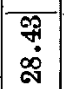 & $\begin{array}{l}\mathscr{8} \\
\dot{\mathscr{m}}\end{array}$ & 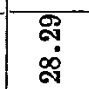 & $\begin{array}{l}\text { क्ष } \\
\text { जे }\end{array}$ & 㐫 & 丞 & $\begin{array}{l}\overrightarrow{5} \\
\dot{10} \\
i\end{array}$ & 동 & 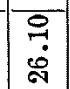 & $\begin{array}{l}\text { वै. } \\
\dot{\vec{\alpha}}\end{array}$ & 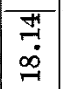 & 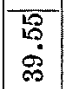 & $\begin{array}{l}\text { क्ष } \\
\stackrel{\text { जे }}{ }\end{array}$ & $\frac{\text { Do }}{\dot{a}}$ & 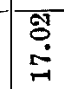 \\
\hline $\begin{array}{l}\text { 엉 } \\
\stackrel{0}{\circ} \\
\text { ㅁ. }\end{array}$ & 量 & $\begin{array}{l}\text { 하 } \\
\text { ลิ่ }\end{array}$ & $\begin{array}{l}\text { में } \\
\text { த் }\end{array}$ & $\stackrel{\circ}{\stackrel{\circ}{\circ}}$ & 艿 & $\begin{array}{l}\vec{\sharp} \\
\stackrel{\leftrightarrow}{8}\end{array}$ & $\begin{array}{l}8 \\
0 \\
0 \\
-9\end{array}$ & 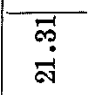 & $\begin{array}{l}\text { 음 } \\
\dot{\leftrightarrow}\end{array}$ & $\begin{array}{l}\vec{b} \\
\dot{0}\end{array}$ & F & $\begin{array}{l}\text { 염 } \\
\dot{+}\end{array}$ & $\begin{array}{l}\text { तु } \\
\text { ळ. }\end{array}$ & 点 & $\begin{array}{l}19 \\
9 \\
8 \\
8 \\
8\end{array}$ & $\stackrel{5}{\circ}$ & 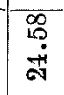 & $\begin{array}{l}\vec{\infty} \\
\stackrel{0}{0}\end{array}$ \\
\hline 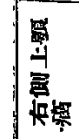 & 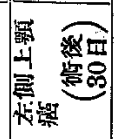 & 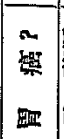 & $\mid$ & 紫 & 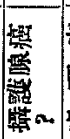 & 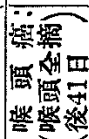 & 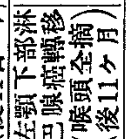 & 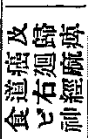 & 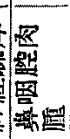 & 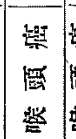 & 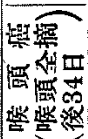 & 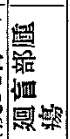 & 8 & 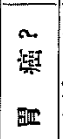 & 鄢 & 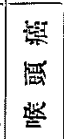 & 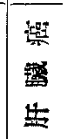 & 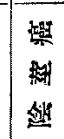 \\
\hline$\underset{\infty}{N}$ & $\frac{x}{10}$ & $\frac{x}{\infty}$ & $\underset{A}{\Phi}$ & $\frac{x}{\exists}$ & $\stackrel{\mathscr{A}}{\varrho}$ & $\underset{\mathcal{N}}{\mathcal{N}}$ & $\frac{\mathbb{A}}{\not ⿰ 习 习}$ & $\frac{\mathscr{N}}{\widehat{\sigma}}$ & $\frac{\otimes}{a}$ & $\frac{1}{6}$ & $\frac{\nabla}{6}$ & $\frac{8}{0}$ & $\frac{8}{0}$ & $\frac{\theta}{0}$ & $\exists$ & $\stackrel{\Xi}{\triangle}$ & $\stackrel{\searrow}{\mathrm{I}}$ & $\stackrel{\nabla}{\Theta}$ \\
\hline 愊 & to $\dot{\bar{S}}$ & 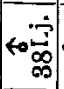 & for & \&o & \& & ه & భూ & ه & to: & स० & ४० 宊 & to & of & ot & \&o & toi & to & 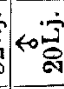 \\
\hline $\begin{array}{l}N \\
O \\
H \\
O \\
\end{array}$ & $\begin{array}{l}4 \\
0\end{array}$ & $\begin{array}{l}0 \\
0 \\
K\end{array}$ & $\begin{array}{l}0 \\
4\end{array}$ & 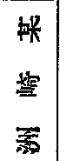 & 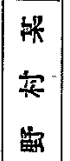 & 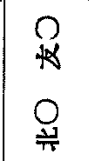 & $\begin{array}{l}\text { O } \\
\text { 뉴 }\end{array}$ & $\begin{array}{l}0 \\
\text { 裸 } \\
0 \\
\text { 侣 }\end{array}$ & $\begin{array}{l}0 \\
0 \\
0\end{array}$ & $\begin{array}{l}0 \\
0 \\
? \\
?\end{array}$ & 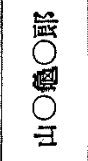 & 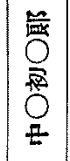 & $\begin{array}{l}0 \\
\text { 濑 } \\
0 \\
0\end{array}$ & $\begin{array}{l}0 \\
\therefore \\
0 \\
0 \\
\text { 원 }\end{array}$ & $\begin{array}{l}0 \\
0 \\
+1\end{array}$ & 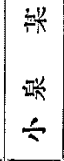 & $\begin{array}{l}0 \\
+ \\
0 \\
9 \\
0\end{array}$ & $\begin{array}{l}P \\
1 \\
0 \\
H\end{array}$ \\
\hline$\Xi$ & ? & ส & $\vec{\alpha}$ & สิ & :ึ & er & t & :ै & ज & $\stackrel{\infty}{\mathbf{N}}$ & 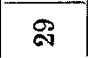 & ஜ & $\vec{c}$ & 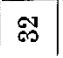 & 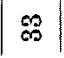 & 荡 & 18 & 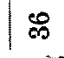 \\
\hline
\end{tabular}




\begin{tabular}{|c|c|c|c|c|c|c|c|c|c|c|c|c|c|c|c|c|c|c|c|}
\hline 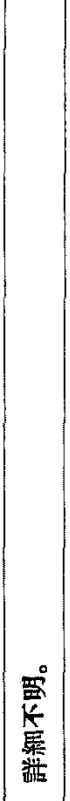 & 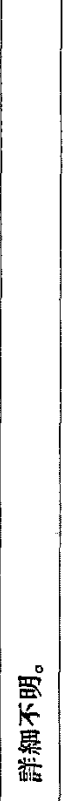 & 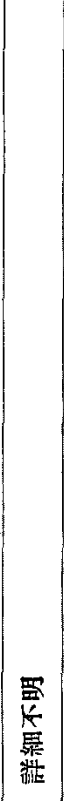 & 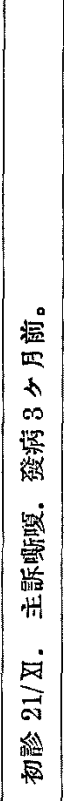 & 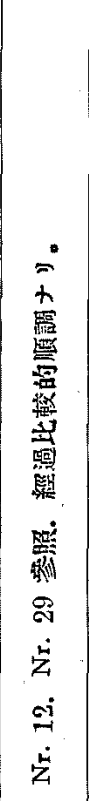 & 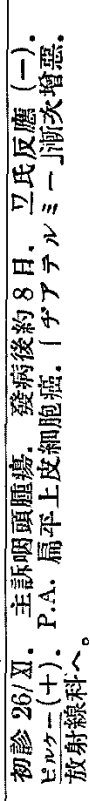 & 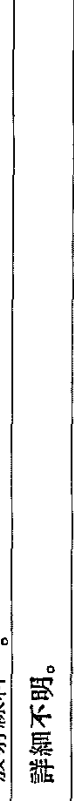 & 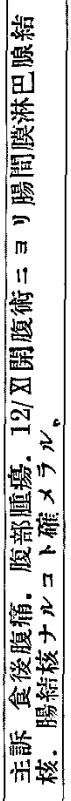 & 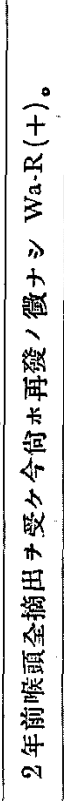 & 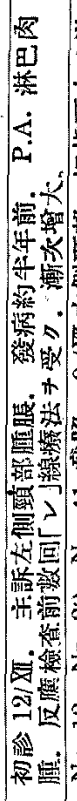 & 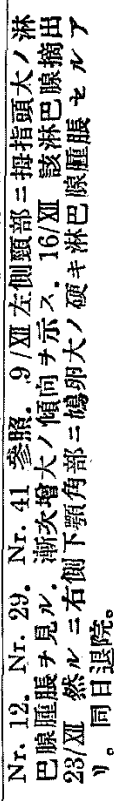 & 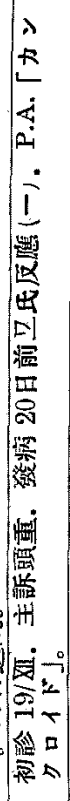 & 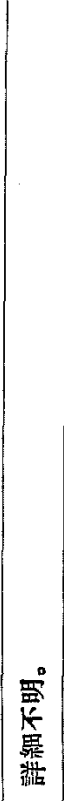 & 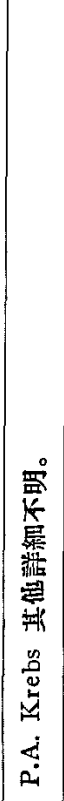 & 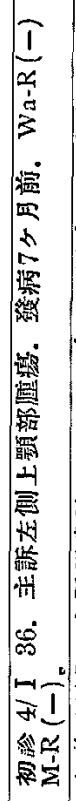 & 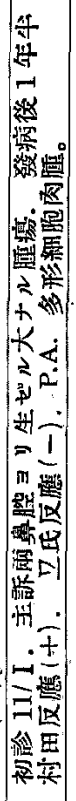 & 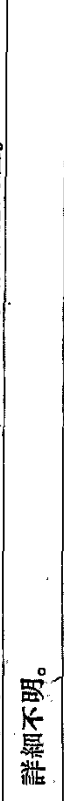 & 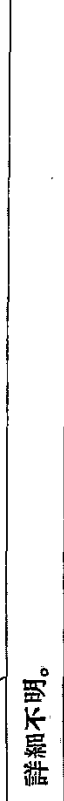 & 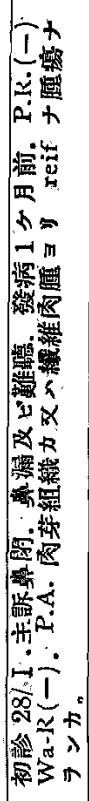 & 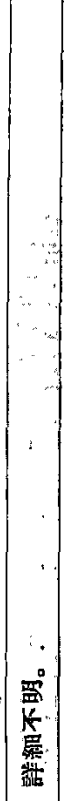 \\
\hline 目 & $m$ & $F$ & $r$ & $\xi$ & $\mapsto$ & 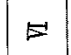 & E & E & $\forall$ & F & $w$ & 寻 & $m$ & 自 & $m$ & 目 & $m$ & $n$ & $\forall$ \\
\hline I & + & + & + & + & + & + & I & 1 & + & + & + & + & + & 1 & + & + & + & + & + \\
\hline 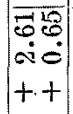 & 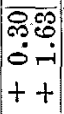 & $\begin{array}{l}\delta_{0}^{\infty} \\
\dot{a} \dot{+} \\
1+\end{array}$ & $\begin{array}{l}0 \overline{0} \\
\because 0 \\
0 \\
+\overline{9}\end{array}$ & 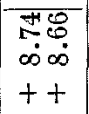 & 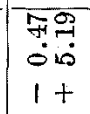 & 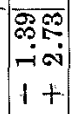 & $\left|\begin{array}{cc|}0 & 0 \\
0 & 0 \\
0 & 0 \\
+ & 0\end{array}\right|$ & 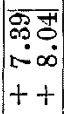 & $\begin{array}{ccc}5 & \\
0 & 0 \\
0 & 0 \\
1 & \\
1\end{array}$ & $\begin{array}{l}\mathscr{8} \\
\dot{H}+4 \\
++\end{array}$ & 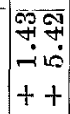 & $\begin{array}{cc}\infty & 0 \\
-1 & 0 \\
1 & 0 \\
1 & 1\end{array}$ & 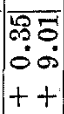 & 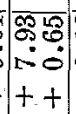 & $\begin{array}{ll}0 & 10 \\
0 & 0 \\
1 & +\end{array}$ & 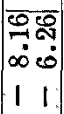 & $\begin{array}{l}2 \\
0 \\
00 \\
+1 \\
+1\end{array}$ & 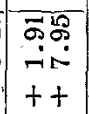 & $\begin{array}{l}\text { कूक } \\
\text { ond } \\
\text { fis } \\
1+4\end{array}$ \\
\hline $\begin{array}{l}10 \\
0 \\
0 \\
9 \\
-1 \\
\end{array}$ & \begin{tabular}{|l}
$\overline{0}$ \\
0 \\
$\dot{m}$ \\
0
\end{tabular} & $\begin{array}{l}: \\
\dot{0} \\
\infty \\
\infty\end{array}$ & $\begin{array}{l}\overrightarrow{0} \\
00 \\
00\end{array}$ & $\begin{array}{l}:= \\
\infty \\
\infty\end{array}$ & $\hat{\dot{\theta}}$ & 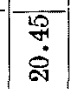 & $\begin{array}{l}\text { नें } \\
\text { कें } \\
0\end{array}$ & $\begin{array}{l}8 \\
\dot{8} \\
\dot{8}\end{array}$ & 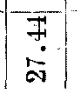 & & $\begin{array}{l}\overrightarrow{1} \\
\dot{g}\end{array}$ & 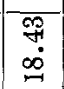 & $\begin{array}{l}\stackrel{H}{\sharp} \\
\Re\end{array}$ & 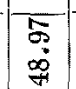 & $\begin{array}{l}\$ \\
\infty \\
\infty \\
0 .\end{array}$ & \begin{tabular}{|l}
0 \\
\multirow{q}{*}{} \\
$\dot{s}$ \\
$\dot{s}$
\end{tabular} & $\begin{array}{l} \\
7 \\
7\end{array}$ & 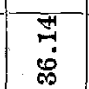 & 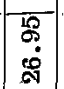 \\
\hline !्: & $\overline{9}$ & \% & 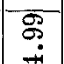 & $\angle \infty$ & 8 & $\mathscr{c o s}$ & $\begin{array}{l}\text { ș } \\
\infty \\
\infty\end{array}$ & एूo & 8 & $\vec{\forall}$ & $I^{-}$ & $\Phi$ & $\infty$ & G & ब্ণ & $\begin{array}{l}\infty \\
0 \\
\end{array}$ & 10 & 9 & $\infty$ \\
\hline ภิ & $\approx$ & ชี & $\vec{\infty}$ & $\infty$ & $\mathscr{ง}$ & $\stackrel{\leftrightarrow}{\sim}$ & 舟 & sิ & $\vec{\Delta}$ & है & $\stackrel{\mathrm{N}}{ }$ & 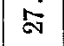 & में & $\ddot{\circ}$ & $\infty$ & $\vec{N}$ & 5 & ஜे & 8 \\
\hline $\begin{array}{l}8 \\
0 \\
\infty \\
\end{array}$ & 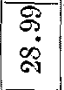 & $\begin{array}{l}\text { की } \\
\text { में } \\
\text { में }\end{array}$ & 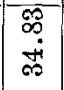 & $\begin{array}{l}\overrightarrow{0} \\
8\end{array}$ & $\begin{array}{l}\stackrel{0}{0} \\
8 \\
8\end{array}$ & \begin{tabular}{l}
\multirow{5}{5}{} \\
$\stackrel{2}{-2}$
\end{tabular} & & 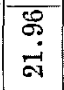 & 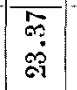 & 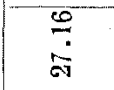 & 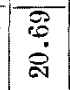 & ब施 & 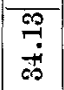 & 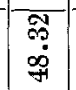 & $\begin{array}{l}\text { 尔 } \\
\stackrel{9}{\circ}\end{array}$ & $\begin{array}{l}0 \\
0 \\
a \\
c \\
c\end{array}$ & 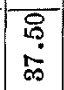 & 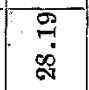 & \\
\hline 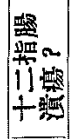 & 畘 & 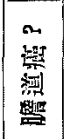 & 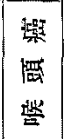 & 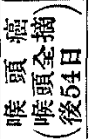 & 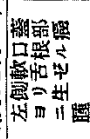 & 峾 & 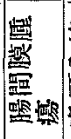 & 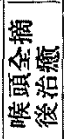 & 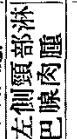 & 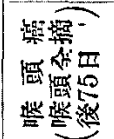 & 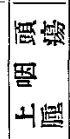 & 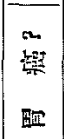 & 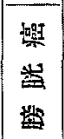 & 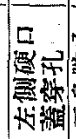 & 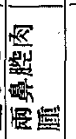 & 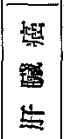 & 望 & 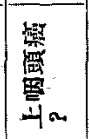 & 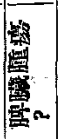 \\
\hline$\frac{1}{19}$ & $\underset{10}{10}$ & $\frac{1}{20}$ & $\stackrel{\otimes}{\lambda}$ & $\underset{ }{\otimes}$ & $\frac{\nexists}{0}$ & $\frac{1}{\infty}$ & 웡 & 园 & 园 & 园 & 斑 & $\overline{\text { 図 }}$ & 园 & 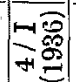 & $\stackrel{H}{\exists}$ & 멋 & $\overline{\frac{1}{\sqrt{N}}}$ & $\underset{7}{=}$ & 是 \\
\hline tro & to & ro & of & स० & 富 & to & ot & to & 垴 & 世 & 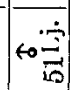 & <० & 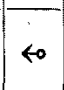 & tô & \&. & to & <ం: & so 寄 & $\mid<0$ \\
\hline $\begin{array}{c}O \\
\text { tin }\end{array}$ & $\begin{array}{l}k \\
\vdots \\
*\end{array}$ & $\begin{array}{l}0 \\
\succ\end{array}$ & 品 & 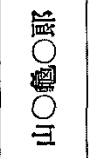 & $\begin{array}{l}0 \\
4\end{array}$ & 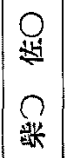 & 娚 & 非 & $\begin{array}{c}0 \\
\text { 柯 }\end{array}$ & 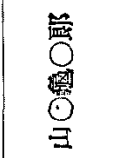 & 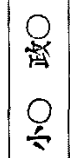 & $\begin{array}{l}0 \\
0 \\
0 \\
4\end{array}$ & 地 & 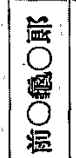 & $\begin{array}{l}0 \\
+ \\
0 \\
\end{array}$ & $\begin{array}{l}* \\
\div\end{array}$ & 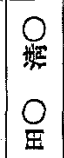 & $\begin{array}{l}0 \\
\text { 站 } \\
0 \\
0\end{array}$ & 3 \\
\hline$\widehat{\infty}$ & $\stackrel{\infty}{\infty}$ & $\infty$ & F & H & 구 & $\stackrel{g}{*}$ & $\mathbb{F}$ & F & 와 & 尔 & $\stackrel{\infty}{\rightarrow}$ & क्ष & దิ & $\overrightarrow{B D}$ & 周 & 80 & $\overrightarrow{0}$ & (5) & $\overline{10}$ \\
\hline
\end{tabular}




\begin{tabular}{|c|c|c|c|c|c|c|c|c|c|c|c|c|c|c|c|c|c|c|}
\hline 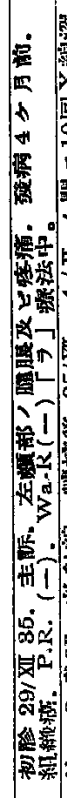 & 跑 & 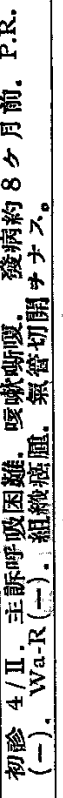 & 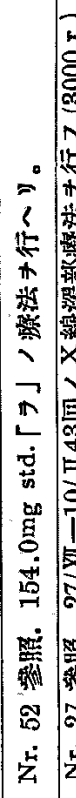 & 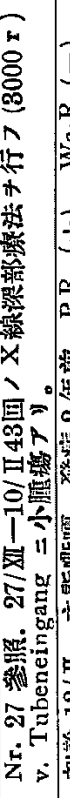 & 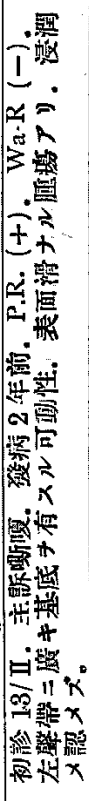 & 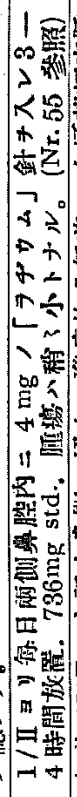 & 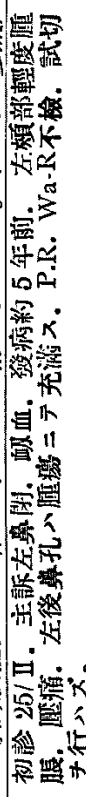 & 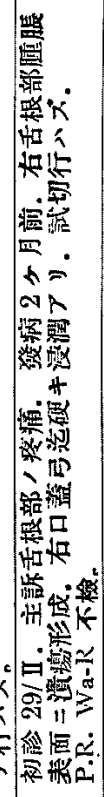 & 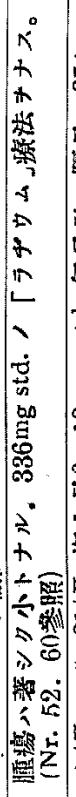 & 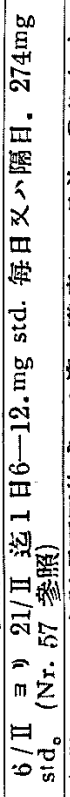 & 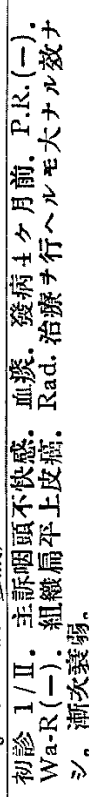 & 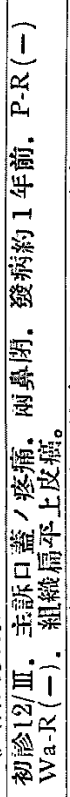 & 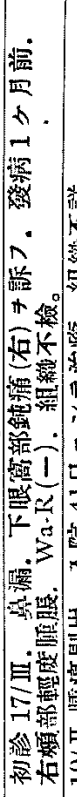 & 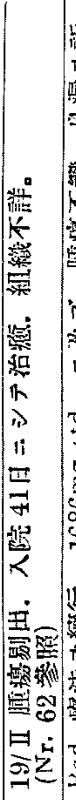 & 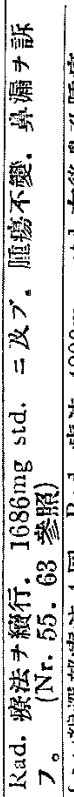 & 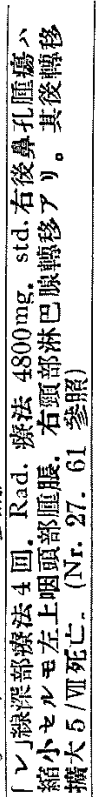 & 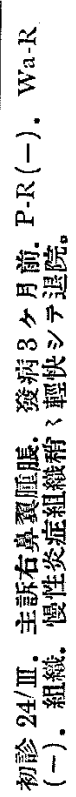 & 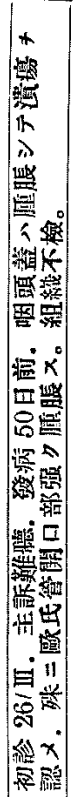 \\
\hline 日 & F & $m$ & $\begin{array}{l}\text { 是 } \\
+ \\
-1\end{array}$ & $t$ & 日 & $\begin{array}{l}\text { E } \\
+ \\
+\end{array}$ & $\Sigma$ & $\mapsto$ & $\Rightarrow$ & $b$ & 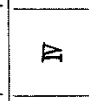 & $\mapsto$ & $\mapsto$ & 目 & 目 & 目 & 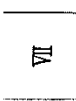 & 目 \\
\hline+ & + & + & + & + & + & + & + & + & + & + & + & + & + & + & + & + & I & + \\
\hline 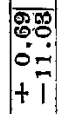 & $\begin{array}{l}\infty 10 \\
0.15 \\
0 \\
+1\end{array}$ & 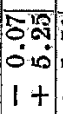 & $+t+t$ & 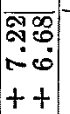 & $\begin{array}{l}\overrightarrow{60} \\
\text { i. } \\
11 \\
11\end{array}$ & 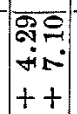 & $\begin{array}{l}109 \\
\text { in } \\
1+1 \\
1+1\end{array}$ & 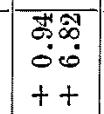 & \begin{tabular}{r}
$\exists \infty$ \\
\hdashline 0 \\
+1 \\
+1
\end{tabular} & 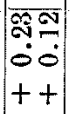 & $\begin{array}{l}85 \\
00 \\
00 \\
1+\end{array}$ & $\mid \begin{array}{c}50 \\
0 \\
0 \\
0+4 \\
1+\end{array}$ & 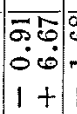 & 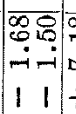 & 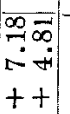 & $\begin{array}{l}\text { Eक } \\
-i \infty \\
11\end{array}$ & $\begin{array}{l}\infty \\
\infty_{0}^{\infty} \\
\dot{+1} \\
++\end{array}$ & $\begin{array}{l}\dot{2} 0 \\
11\end{array}$ \\
\hline 8 & 8 & 5 & $\bar{\infty}$ & एू & $\widehat{0}$ & $\not 0$ & 8 & J & \% & 40 & 8 & 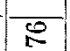 & 5 & $\sqrt{\sigma}$ & $\mathscr{N}$ & $g$ & $\mathscr{g}$ & 孚 \\
\hline ले & ळ. & ผ & $\dot{\alpha}$ & $\infty$ & มี่ & 19 & 茄 & 今 & ڤั & है & சै & 今े & $\vec{N}$ & เง & ชิ & $\check{\pi}$ & of & o. \\
\hline ฟิ & $m$ & 8 & คิ & कृ & $\stackrel{5}{\circ}$ & 5 & 8 & $\mathscr{C}$ & 象 & $\mathscr{m}$ & ন্ষি & 초 & 8 & $\vec{F}$ & 8 & $\overrightarrow{0}$ & क् & $\infty$ \\
\hline मे & $\approx$ & $\stackrel{0}{\circ}$ & 10 & : & สิ่ & कึ & ลง & $\overrightarrow{\mathrm{N}}$ & $\overrightarrow{~ ल े ~}$ & कू & เ્ง & $\dot{0}$ & $\Xi$ & 19 & 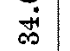 & $\stackrel{-1}{-1}$ & s & की \\
\hline 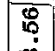 & 19 & $a$ & $?$ & $\mp$ & 通 & क & 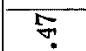 & $\widetilde{\pi}$ & T & 9 & 9 & $\stackrel{8}{0}$ & 8 & 원 & 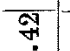 & 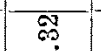 & 8 & 品 \\
\hline$\infty$ & 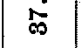 & $\stackrel{\infty}{\sim}$ & \&் & ส่ & เே่ & 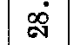 & $\vec{\infty}$ & ลิ่ & $\vec{\omega}$ & . & เ⿺辶่ & $\dot{\theta}$ & $\stackrel{\infty}{\oplus}$ & 5 & a & $\dot{\Delta}$ & $\overrightarrow{\text { ज }}$ & $\infty$ \\
\hline 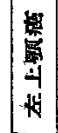 & 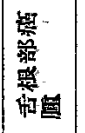 & 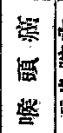 & 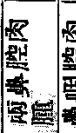 & 量 & 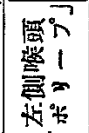 & 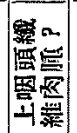 & 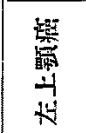 & 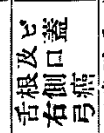 & 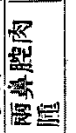 & 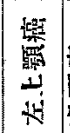 & 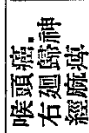 & 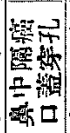 & & 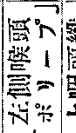 & 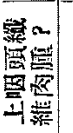 & 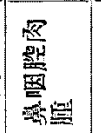 & 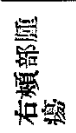 & 兽 \\
\hline 분 & $\frac{1}{0}$ & 是 & 봉 & 禁 & 星 & 昌 & 畼 & $\mathscr{s}$ & 目 & $\frac{\text { 是 }}{\mathrm{s}}$ & $\begin{array}{l}\text { 目总 } \\
\text { 的惫 }\end{array}$ & 是 & 慁 & 园 & 园 & 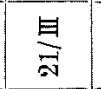 & 쿵 & 䍐 \\
\hline 愘 & to & $\pi$ & +os & 位 & so: & to & 驼宕 & \&o & 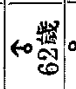 & 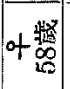 & \& & 棉 & +1 & $\infty$ & 宅 & . & of & to \\
\hline 0 & $\begin{array}{l}O \\
x\end{array}$ & 兹 & SO & 㨐 & 米 & 科 & $\begin{array}{l}\text { O } \\
\Rightarrow\end{array}$ & 量 & O & 0 & $\overrightarrow{n=}$ & 政 & 0 & 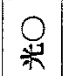 & 濎 & 0 & 0 & \\
\hline 面 & $\begin{array}{l}0 \\
4\end{array}$ & 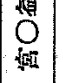 & 0 & $\mathrm{O}_{\mathrm{I}}$ & 承 & 燎 & 道 & 蓝 & 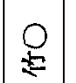 & iII & $\begin{array}{l}0 \\
0\end{array}$ & $\frac{O}{15}$ & 长 & 茟 & & 点 & 울 & 䎂 \\
\hline & 10 & $g$ & 8 & 6 & 잉 & है & పే & 18 & 8 & 5 & $\approx$ & 8 & i & $E$ & $\hat{i}$ & r & - & 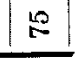 \\
\hline
\end{tabular}




\begin{tabular}{|c|c|c|c|c|c|c|c|c|c|c|c|c|c|c|c|c|c|c|}
\hline 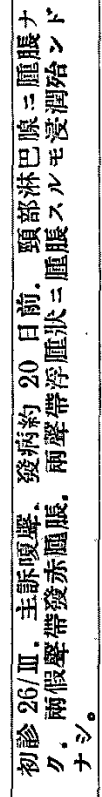 & 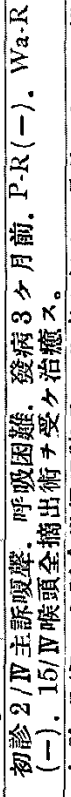 & 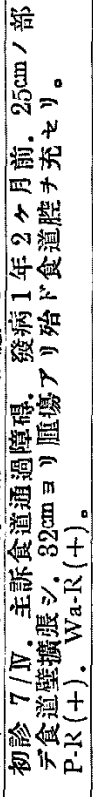 & 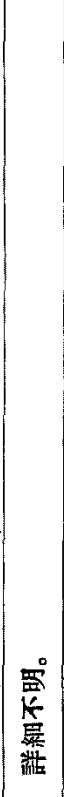 & 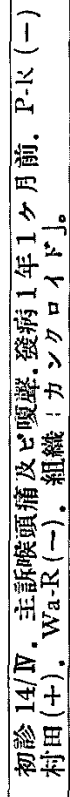 & 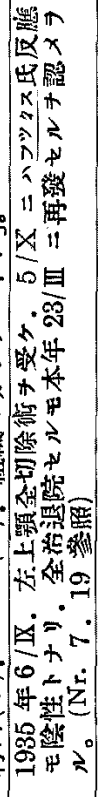 & 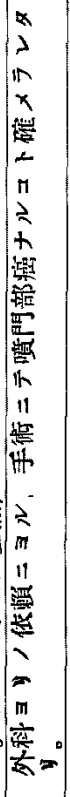 & 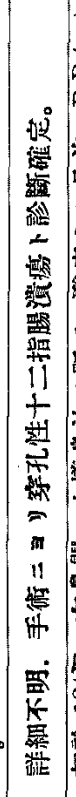 & 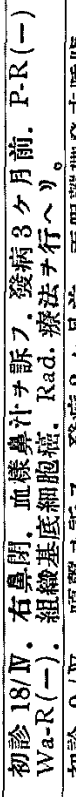 & 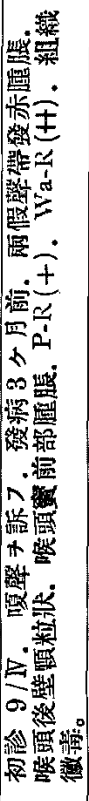 & 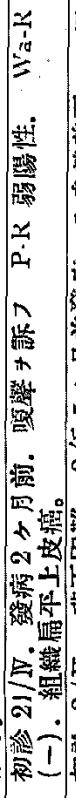 & 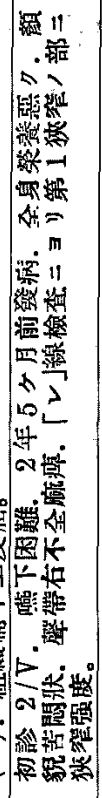 & 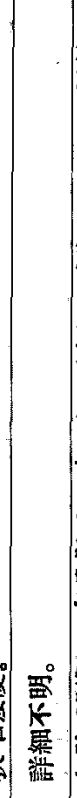 & 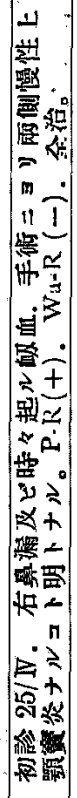 & 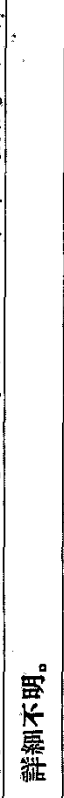 & 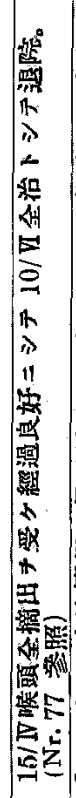 & 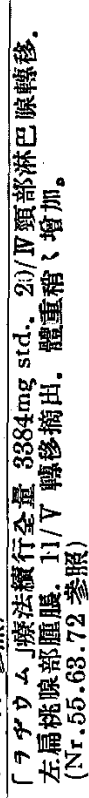 & 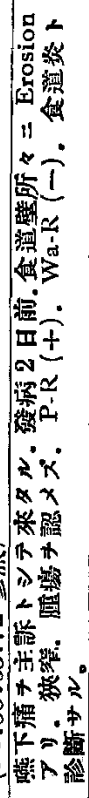 & 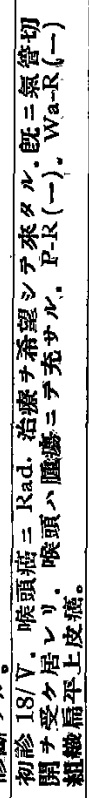 \\
\hline 目 & $\begin{array}{l}\text { 早 } \\
+\end{array}$ & $\mapsto$ & $\mapsto$ & 5 & - & 日 & $\triangle$ & - & 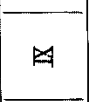 & $m$ & - & $\mapsto$ & 目 & -1 & & 目 & 目 & \\
\hline 1 & + & + & & + & + & + & & + & & + & + & & 1 & 1 & 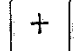 & & & \\
\hline & 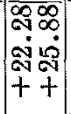 & $\begin{array}{l}84 \\
60 \\
0.4 \\
++\end{array}$ & & $\mid \begin{array}{ll}\infty & 0 \\
0 & 0 \\
0 & 0 \\
++1\end{array}$ & $\begin{array}{l}\infty \\
\infty \\
0 \\
0: \\
0 \\
+1\end{array}$ & 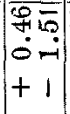 & $\mid \begin{array}{cc}8 & 8 \\
0 & - \\
+1 & -1\end{array}$ & $\left.\mid \begin{array}{cc}7 & 0 \\
0 & 0 \\
0 & \infty \\
1 & +\end{array}\right]$ & \begin{tabular}{l} 
oूa \\
\hdashline-1 \\
+1
\end{tabular} & $\begin{array}{l}5 \\
0 \\
0 \\
0 \\
+++\end{array}$ & $\begin{array}{l}8 \\
\dot{8} \\
+ \\
+\end{array}$ & $1+$ & + & 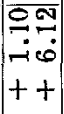 & 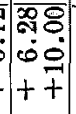 & & & \\
\hline $\begin{array}{l}\text { 암 } \\
\text { सं }\end{array}$ & 角 & $\bar{m}$ & & & & & $\begin{array}{l}\mathscr{8} \\
\dot{\vec{\pi}}\end{array}$ & & & & & & & & & & & \\
\hline ". & $\begin{array}{l}8 \\
+\end{array}$ & $\begin{array}{l}\mathscr{8} \\
: \\
\text { वें }\end{array}$ & & & & & & & & & & & $\approx$ & & & & & \\
\hline है & $\begin{array}{l}\text { बू } \\
\text { สं }\end{array}$ & & & & & & & & & & & & & & & & & \\
\hline 喓 & 僢 & 徨 & 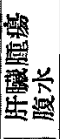 & 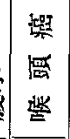 & 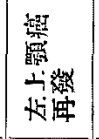 & 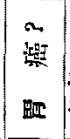 & 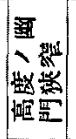 & & & 整 & $\begin{array}{l}\text { 漂 } \\
\text { 你 }\end{array}$ & 靕 & & $\left\{\begin{array}{l}\text { 紫 } \\
\text { 政 }\end{array}\right.$ & 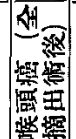 & & & 曒 \\
\hline 是 & 5 & & $\underline{0}$ & 든 & & & $r$ & & & & & & & & & & & \\
\hline 住 & oot $\dot{5}$ & & ot & & स० & & 世: & $\begin{array}{rl}0 & \dot{3} \\
0 & 0 \\
0\end{array}$ & to & 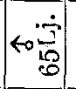 & <0 & to $\frac{\dot{a}}{0}$ & of & . & of & $1^{+\circ}=$ & $\overline{16}$ & 5 \\
\hline 努 & 6 & 学 & C & 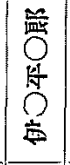 & 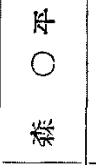 & k & $\Omega$ & 相 & $m$ & 78 & 紧学 & $x=$ & 通 & 4 & $\pi^{\prime \prime}$ & 社 & 0 & 学 \\
\hline 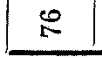 & $E$ & & & $\varnothing$ & & & & め゙ & & & & & $\not \infty$ & & & & & \\
\hline
\end{tabular}




\begin{tabular}{|c|c|c|c|c|c|c|c|c|c|c|c|c|c|c|c|}
\hline 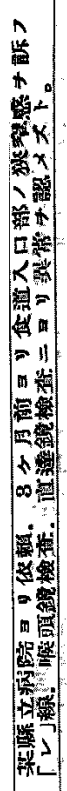 & 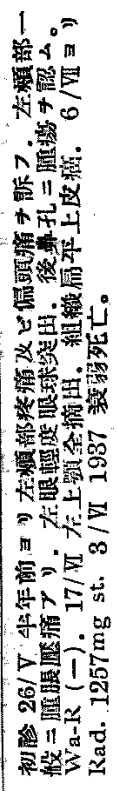 & 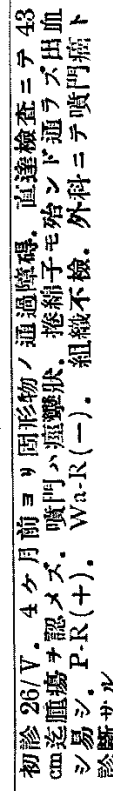 & 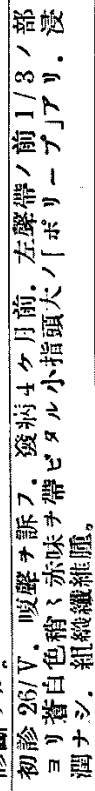 & 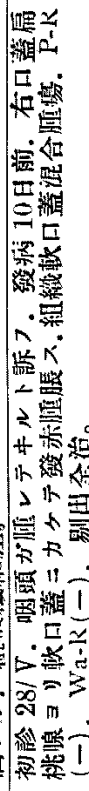 & 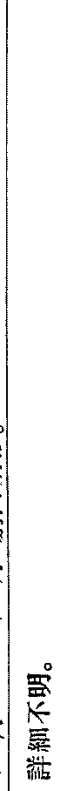 & 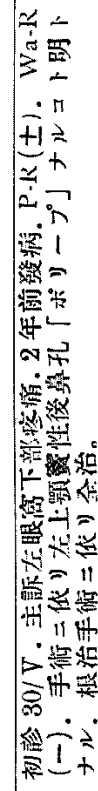 & 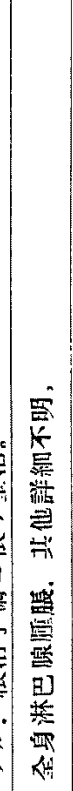 & 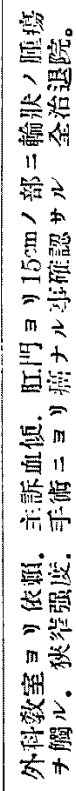 & 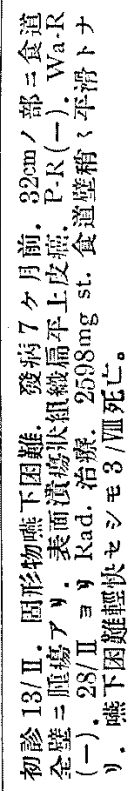 & 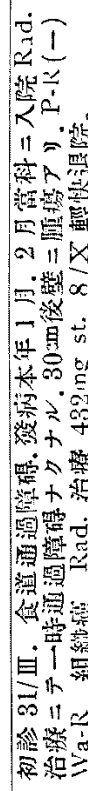 & 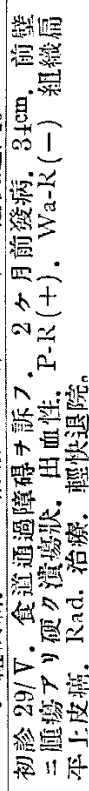 & 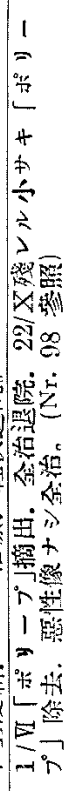 & 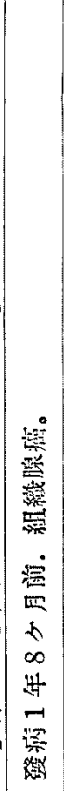 & 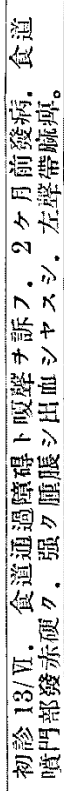 & 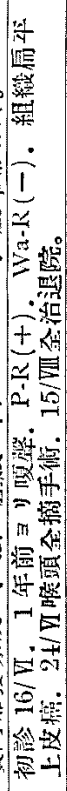 \\
\hline$凶$ & $b$ & 目 & $\nexists$ & $m$ & 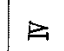 & 目 & $w$ & 曰 & 日 & $\mapsto$ & 曰 & $\otimes$ & $\Rightarrow$ & $\Rightarrow$ & $\exists$ \\
\hline 1 & + & 1 & $t$ & + & + & 1 & + & + & + & + & + & 1 & + & + & + \\
\hline 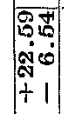 & $\begin{array}{r}8 \\
0 \\
0 \\
1\end{array}$ & $\begin{array}{ll}\overrightarrow{0} & \vec{\sigma} \\
\dot{0} & 0 \\
+ & +\end{array}$ & $\begin{array}{l}\text { fo: } \\
-i 0 \\
1+\end{array}$ & 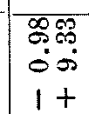 & $\begin{array}{l}08 \\
-0 \\
1+0 \\
-0\end{array}$ & 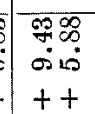 & 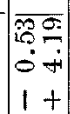 & $\begin{array}{c}\infty \hat{\theta} \\
\dot{\theta} \hat{\theta} \\
11\end{array}$ & 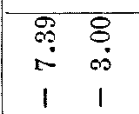 & $\begin{array}{l}90 \\
9: \\
+1 \\
++\end{array}$ & $\begin{array}{ll}5 & \infty \\
0 \\
0 \\
1 & 1 \\
1 & 1\end{array}$ & $\begin{array}{l}\bar{s} 0 \\
\dot{a} 0 \\
+1\end{array}$ & 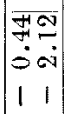 & $=\frac{\vec{E}}{1}$ & 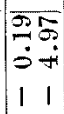 \\
\hline : & 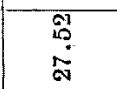 & 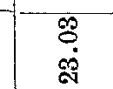 & $\begin{array}{l}\text { to } \\
\text { : }\end{array}$ & 8 & 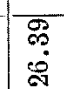 & 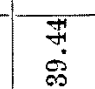 & $\begin{array}{l}8 \\
0 \\
0 \\
0 \\
0\end{array}$ & $\begin{array}{l}8 \\
\stackrel{0}{\sim}\end{array}$ & 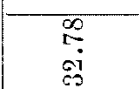 & $\begin{array}{l}0 \\
\stackrel{0}{\circ} \\
0\end{array}$ & : & 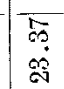 & 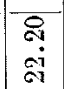 & $\begin{array}{l}\mathscr{0} \\
\stackrel{6}{\circ} \\
\dot{c}\end{array}$ & $\begin{array}{l}\text { g: } \\
\text { : } \\
\text { ลิ่ }\end{array}$ \\
\hline 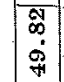 & 菑 & รั & 8 & $\begin{array}{l}19 \\
7 \\
017\end{array}$ & $\begin{array}{l}\text { 연 } \\
\text { tं }\end{array}$ & $\begin{array}{l}8 \\
\stackrel{8}{5} \\
\text { on }\end{array}$ & $\begin{array}{l}\vec{b} \\
\dot{0}\end{array}$ & $\begin{array}{l}\vec{\infty} \\
\vec{\omega}\end{array}$ & $\begin{array}{l}\text { के } \\
\stackrel{a}{\circ}\end{array}$ & $\begin{array}{l}8 \\
\dot{0} \\
\dot{0}\end{array}$ & $\overrightarrow{0}$ & 果 & $\begin{array}{l}\infty \\
\infty \\
\infty \\
\infty\end{array}$ & 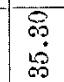 & $\vec{\sigma}$ \\
\hline א্ & $\begin{array}{l}\overrightarrow{0} \\
\text { 产 }\end{array}$ & $\begin{array}{l}\text { क्ष } \\
\text { สं }\end{array}$ & 实 & श̊. & 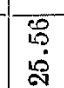 & $\begin{array}{l}18 \\
68 \\
50 \\
50\end{array}$ & T & $\begin{array}{l}\text { \% } \\
\text { : }\end{array}$ & 6 & $\stackrel{8}{\stackrel{8}{\circ}}$ & $\begin{array}{l}\infty \\
\stackrel{\infty}{\circ} \\
\stackrel{0}{\circ}\end{array}$ & $\stackrel{\infty}{\stackrel{\infty}{*}}$ & $\begin{array}{l}a \\
a \\
a d \\
a\end{array}$ & $\begin{array}{l}8 \\
\infty \\
\infty \\
\infty\end{array}$ & $\begin{array}{c}8 \\
\dot{8} \\
\stackrel{9}{9}\end{array}$ \\
\hline 消 & 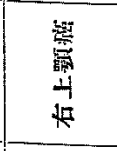 & 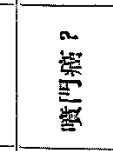 & 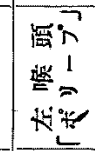 & 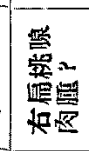 & 䟔 & 亲 & 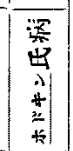 & 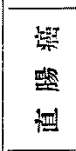 & 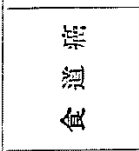 & 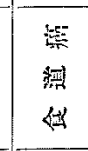 & $\begin{array}{l}\text { 憕 } \\
\text { 浔 } \\
\text { 出 }\end{array}$ & 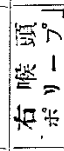 & $\overrightarrow{E_{*}}$ & 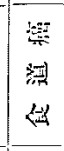 & $\begin{array}{l}\text { 拁 } \\
\text { 뿔 }\end{array}$ \\
\hline a & $\underset{a}{*}$ & $\underset{⿱ 亠 乂}{\stackrel{\Delta}{a}}$ & 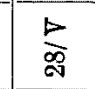 & $\stackrel{b}{\infty}$ & $\underline{-1}$ & $\frac{E}{\infty}$ & $\frac{1}{6}$ & $\begin{array}{l}100 \\
0.00 \\
0.0\end{array}$ & $\frac{1}{6}$ & $\frac{1}{0}$ & $\underset{\text { ลे }}{\text { Es }}$ & $\frac{E}{0}$ & $\frac{5}{\infty}$ & $\frac{1}{19}$ & $\stackrel{5}{\infty}$ \\
\hline स्विके & 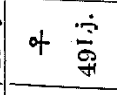 & to 完 & 40. & 仿 & to $\frac{3}{6}$ & 姲 & 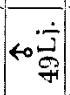 & of $\overline{6}$ & 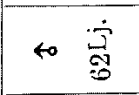 & <० $\frac{9}{8}$ & to & $\begin{array}{r}0 . \dot{3} \\
0 \\
0 \\
0\end{array}$ & of & to & $<0$ \\
\hline 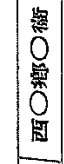 & 葛 & 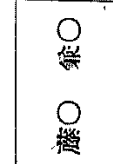 & 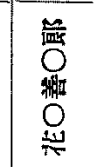 & 是 & 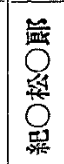 & 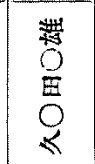 & 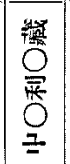 & 晓 & 品 & $\begin{array}{l}\stackrel{a}{0} \\
0 \\
0\end{array}$ & 谓 & 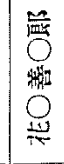 & $\begin{array}{l}0 \\
0 \\
0 \\
\text { 田 }\end{array}$ & 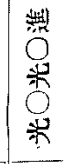 & E \\
\hline 10 & $\stackrel{8}{\circ}$ & ธ్ర & $\stackrel{\infty}{\circ}$ & $\&$ & $\underset{్}{\stackrel{9}{-1}}$ & $\vec{\theta}$ & $\stackrel{9}{\circ}$ & $\stackrel{\mathscr{\Xi}}{\varrho}$ & 总 & $\stackrel{10}{8}$ & $\stackrel{8}{8}$ & 5 & $\stackrel{8}{O}$ & $\stackrel{8}{9}$ & $\Xi$ \\
\hline
\end{tabular}




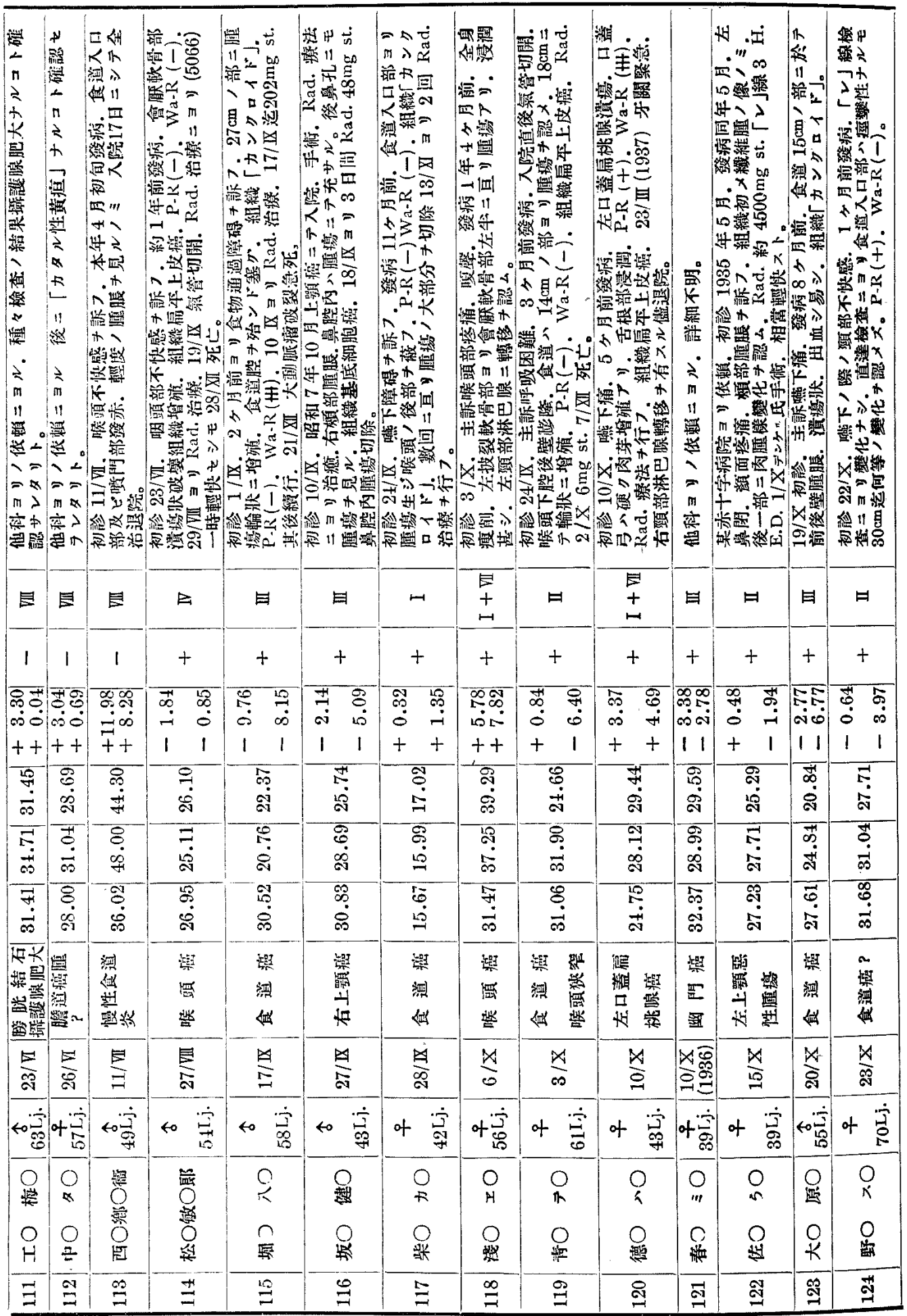




\begin{tabular}{|c|c|c|c|c|c|c|c|c|c|c|c|c|c|}
\hline 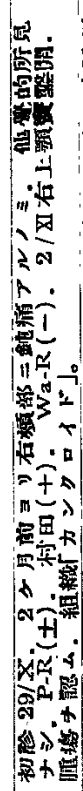 & 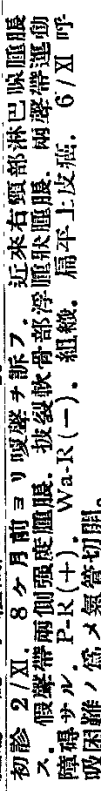 & 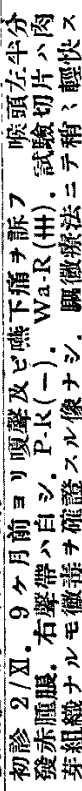 & 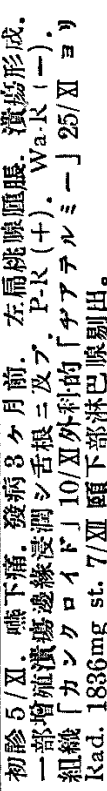 & 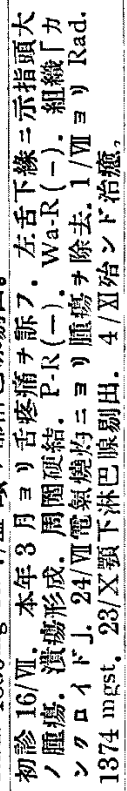 & 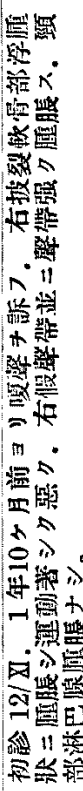 & 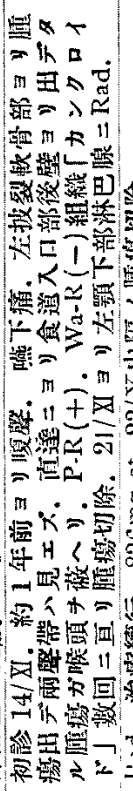 & 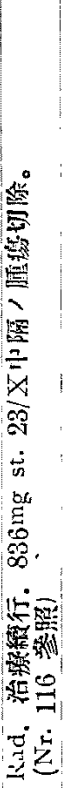 & 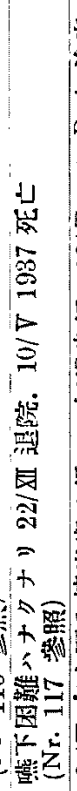 & 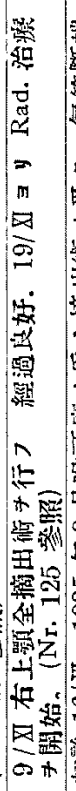 & 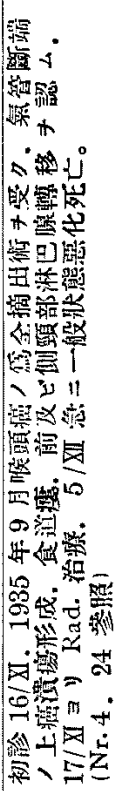 & 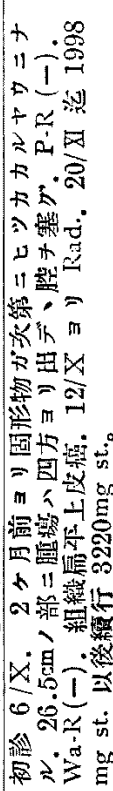 & 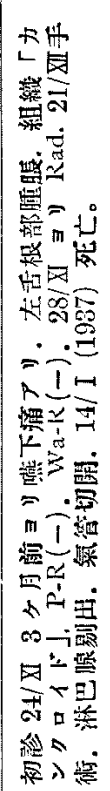 & 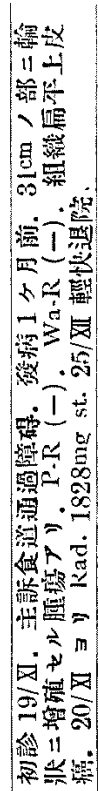 \\
\hline 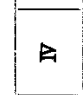 & 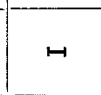 & E & $\mapsto$ & 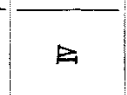 & $\nexists$ & $\mapsto$ & 目 & $\mapsto$ & 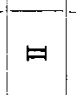 & 日 & 目 & $\mapsto$ & $\begin{array}{l}E \\
+ \\
+\end{array}$ \\
\hline+ & + & 1 & + & + & + & + & + & + & + & + & 1 & + & + \\
\hline 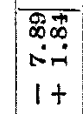 & 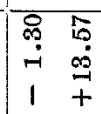 & 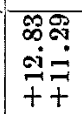 & \begin{tabular}{cc}
0 & $\infty$ \\
\hdashline & $\stackrel{0}{2}$ \\
1 & +
\end{tabular} & $\begin{array}{ll}\mathbb{N} \\
\stackrel{5}{5} \\
1 & 1 \\
1 & 1\end{array}$ & 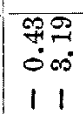 & $\begin{array}{ll}\stackrel{0}{0} & 8 \\
\stackrel{0}{0} & 0 \\
0 & 0 \\
+ & +\end{array}$ & $\begin{array}{ll}g & \overline{5} \\
0 & 7 \\
1 & 1\end{array}$ & $\mid \begin{array}{ll}0 & 0 \\
0 & 0 \\
0 & 0 \\
+ & 0 \\
+ & 0\end{array}$ & $\mid \begin{array}{cc}10 & 0 \\
0 & 0 \\
0 & 0 \\
1 & 1\end{array}$ & $\begin{array}{cc}0 & 9 \\
0 & 9 \\
0 & +1 \\
1 & 1\end{array}$ & $\begin{array}{ll}\stackrel{\infty}{\infty} & \mathscr{g} \\
\stackrel{0}{\circ} & 0 \\
+ & +\end{array}$ & 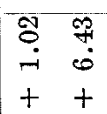 & 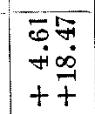 \\
\hline 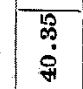 & 官 & $\begin{array}{l}2 \\
5 \\
5\end{array}$ & $\begin{array}{l}\text { co } \\
\dot{0}\end{array}$ & $\begin{array}{l}\mathbb{E} \\
\stackrel{0}{0} \\
\dot{0}\end{array}$ & $\frac{\dot{0}}{\sim}$ & $\begin{array}{l}0 \\
0 \\
0 \\
0\end{array}$ & $\begin{array}{l}0 \\
\stackrel{0}{0} \\
\stackrel{0}{0}\end{array}$ & $\begin{array}{l}\text { 等 } \\
\text { 芴 }\end{array}$ & $\begin{array}{l}\stackrel{5}{\vec{G}} \\
\vec{G}\end{array}$ & $\begin{array}{l}\text { 告 } \\
\text { ลें }\end{array}$ & $\begin{array}{l}\infty \\
\vdots \\
8\end{array}$ & 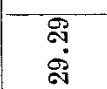 & 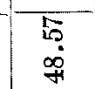 \\
\hline 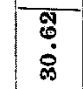 & 笋 & $\begin{array}{l}\text { क्ष } \\
\text { ज্ }\end{array}$ & $\begin{array}{l}8 \\
\infty \\
\infty\end{array}$ & $\begin{array}{l}\text { to } \\
\text { ते }\end{array}$ & $\begin{array}{l}\text { से } \\
\text { ते }\end{array}$ & 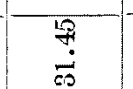 & 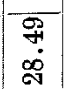 & $\begin{array}{l}\qquad 8 \\
i \\
i\end{array}$ & 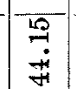 & $\begin{array}{l}\mathscr{g} \\
\stackrel{8}{9}\end{array}$ & 鹠 & 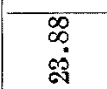 & ت्में \\
\hline $\begin{array}{l}\overline{1} \\
\infty \\
\infty\end{array}$ & 品 & 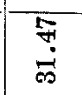 & 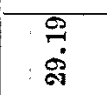 & 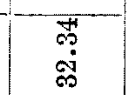 & 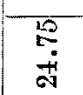 & $\stackrel{\infty}{\infty}$ & $\begin{array}{c}\overline{5} \\
\dot{4} \\
\dot{0}\end{array}$ & $\begin{array}{l}\text { 果 } \\
\text { มี }\end{array}$ & $\begin{array}{l}8 \\
\text { f }\end{array}$ & $\begin{array}{l}10 \\
\infty \\
\dot{3}\end{array}$ & $\begin{array}{l}\mathscr{8} \\
\dot{0} \\
\dot{0}\end{array}$ & $\begin{array}{l}\mathscr{8} \\
\text { มे }\end{array}$ & $\begin{array}{l}\text { ㅇ. } \\
\stackrel{0}{8}\end{array}$ \\
\hline 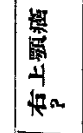 & 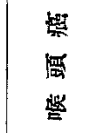 & 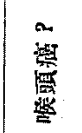 & 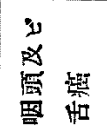 & 濯 & 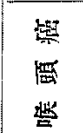 & $\begin{array}{l}\text { 翡 } \\
\text { 澳 } \\
\text { 保 }\end{array}$ & 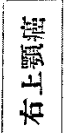 & $\begin{array}{l}\text { 紫 } \\
\text { 䵊 } \\
\text { 保 }\end{array}$ & 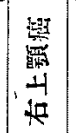 & 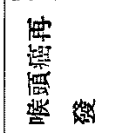 & $\begin{array}{l}\text { 賒 } \\
\text { 勰 } \\
\text { 伿 }\end{array}$ & 岍 & 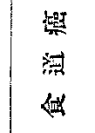 \\
\hline ลิ & $\frac{8}{N}$ & $\frac{\nabla}{a}$ & $\frac{8}{10}$ & $\frac{8}{6}$ & ⿶ & $\frac{\square}{\#}$ & $\underset{\pi}{\mathbb{S}}$ & 因 & $\underset{\sim}{\mathbb{S}}$ & 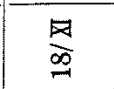 & 봉 & $\underset{A}{\otimes}$ & $\frac{\mathbb{O}}{\stackrel{\circ}{\circ}}$ \\
\hline fos & to 富 & of & to $\frac{\dot{T}}{\mathrm{a}}$ & \&o $: \dot{\dot{s}}$ & 40 & \&o & 客 & F & स्: & to 穴 & to 富 & \&o 空 & <욤 \\
\hline $\begin{array}{l}0 \\
k \\
0 \\
0\end{array}$ & 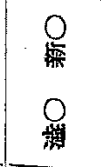 & $\begin{array}{l}O \\
\text { "' } \\
O \\
O\end{array}$ & 䎏 & 蜘 & 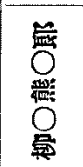 & 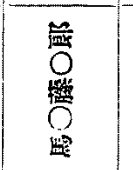 & $\begin{array}{l}0 \\
0 \\
0\end{array}$ & $\begin{array}{l}0 \\
+ \\
0 \\
0 \\
\text { 唯 }\end{array}$ & 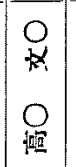 & $\begin{array}{l}0 \\
+\infty \\
0 \\
\stackrel{+1}{T}\end{array}$ & 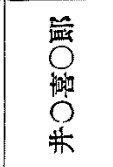 & $\begin{array}{l}\text { 浀 } \\
0 \\
\text { 洫 }\end{array}$ & 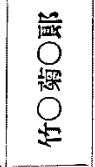 \\
\hline ำ & $\stackrel{9}{9}$ & ลั & 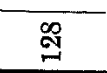 & 茎 & 吕 & $\overrightarrow{\underline{00}}$ & 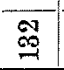 & 茎 & 莺 & 畚 & $\stackrel{\circ}{=}$ & $\stackrel{t a}{\sigma}$ & $\stackrel{2}{2}$ \\
\hline
\end{tabular}




\begin{tabular}{|c|c|c|c|c|c|c|c|c|c|c|c|c|c|}
\hline 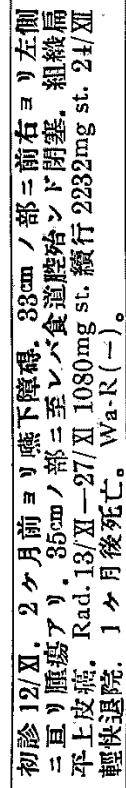 & 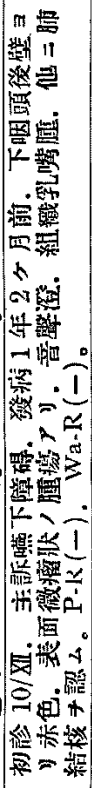 & 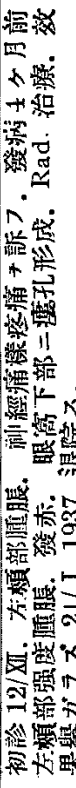 & 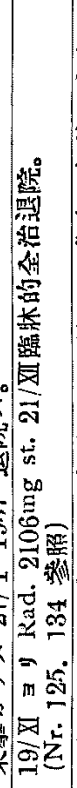 & 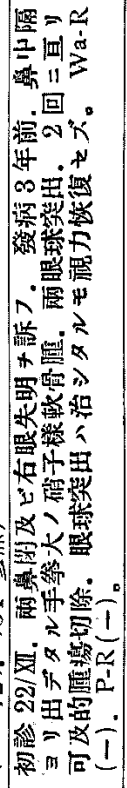 & 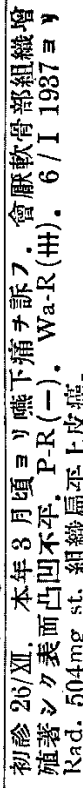 & 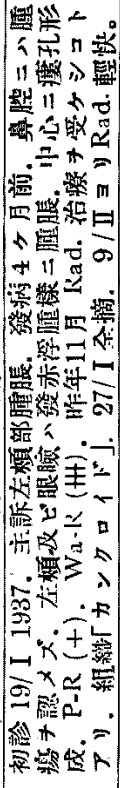 & 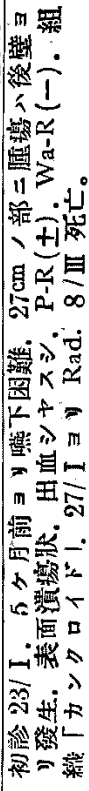 & 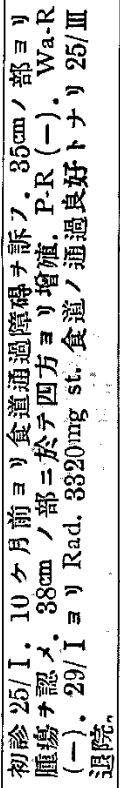 & 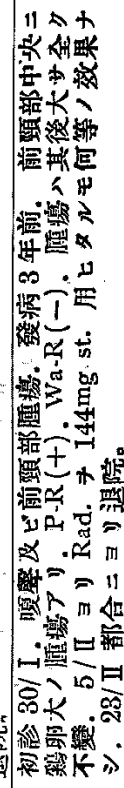 & 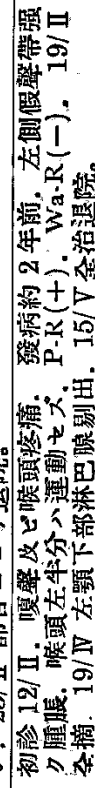 & 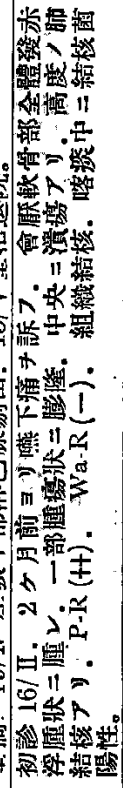 & 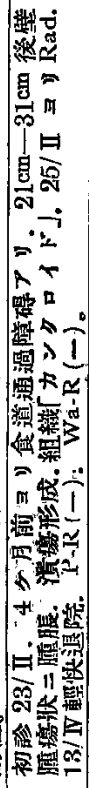 & 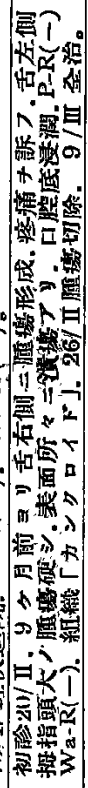 \\
\hline$\mapsto$ & $E$ & $\approx$ & 曰 & 目 & $\mapsto$ & - & $\begin{array}{l}\text { E } \\
+ \\
+\end{array}$ & $\begin{array}{l}\text { E } \\
+ \\
+\end{array}$ & $\therefore$ 目 & 目 & 目 & $\sim$ & 量 \\
\hline+ & 1 & + & + & 1 & + & + & + & + & 1 & + & 1 & + & + \\
\hline 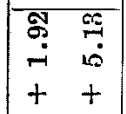 & $\begin{array}{l}\text { 용 } \\
\text { ம் } \\
++\end{array}$ & $\begin{array}{l}5: 0 \\
0.0 \\
10 \\
11\end{array}$ & 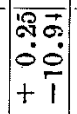 & 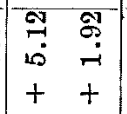 & $\begin{array}{l}\text { T용 } \\
09 \\
1+9\end{array}$ & 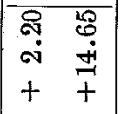 & $\begin{array}{l}\text { क्ष } \\
\stackrel{9}{8} \\
\sim \infty \\
++\end{array}$ & $\begin{array}{|cc|}\infty & \bar{\infty} \\
\infty & \stackrel{0}{0} \\
+ & + \\
\end{array}$ & $\begin{array}{ll}0 & \stackrel{0}{1} \\
\infty & \infty \\
+ & +\end{array}$ & 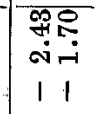 & $\begin{array}{ll}\infty & 0 \\
\infty & \\
0 & \infty \\
7 & 0 \\
+ & +\end{array}$ & $\begin{array}{l}\text { कृष } \\
0 .+1 \\
++\end{array}$ & 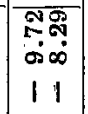 \\
\hline 官 & $\begin{array}{l}0 \\
0 \\
0 \\
\circ\end{array}$ & 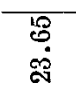 & เి & 离 & च & 里 & $\begin{array}{l}\mathscr{0} \\
\stackrel{\infty}{0}\end{array}$ & $\begin{array}{l}\text { g } \\
\text { ğ }\end{array}$ & 葛 & $\stackrel{\infty}{\infty}$ & $\stackrel{\infty}{\stackrel{9}{\circ}}$ & g. & बุㄱำ \\
\hline $\begin{array}{l}\overline{0} \\
\dot{0}\end{array}$ & 高 & 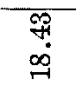 & $\begin{array}{l}10 \\
\stackrel{10}{\circ} \\
0\end{array}$ & $\begin{array}{l}\text { बio } \\
\text { के } \\
\text { के }\end{array}$ & 今ั & $\begin{array}{l}\text { में } \\
0 \\
0\end{array}$ & $\begin{array}{l}\text { கे } \\
\stackrel{\leftrightarrow}{\circ}\end{array}$ & $\begin{array}{l}8 \\
\infty \\
\infty \\
\infty\end{array}$ & & के & & $\begin{array}{l}\text { क्षे. } \\
196\end{array}$ & $\begin{array}{l}\text { : } \\
\dot{8}\end{array}$ \\
\hline $\begin{array}{l}\mathscr{8} \\
\infty \\
\infty \\
\infty\end{array}$ & $\begin{array}{l}\bar{s} \\
\dot{0} \\
\dot{\infty}\end{array}$ & 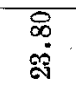 & 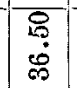 & $\frac{8}{5}$ & $\begin{array}{l}8 \\
\vdots\end{array}$ & $\stackrel{H}{\ddot{m}}$ & 冚 & के & बึ & $\begin{array}{l}\text { के } \\
\text { बें }\end{array}$ & 畩 & $\begin{array}{l}\mathscr{S} \\
\dot{\omega}\end{array}$ & Fi \\
\hline 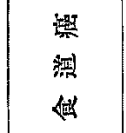 & 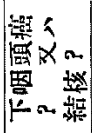 & 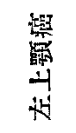 & 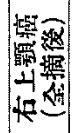 & 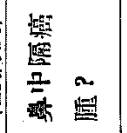 & 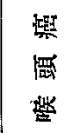 & 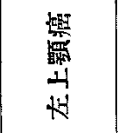 & $\begin{array}{l}\text { 涸 } \\
\text { 促 }\end{array}$ & 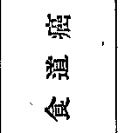 & 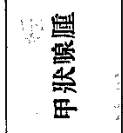 & 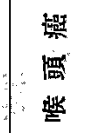 & 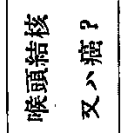 & 撜 & 怙 \\
\hline 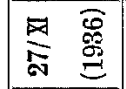 & 붕 & 园 & 츳 & สํำ & 图 & 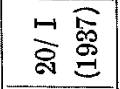 & 畧 & $\stackrel{-19}{\stackrel{9}{9}}$ & 항 & 봉 & $\underset{ }{ }$ & 星 & 点 \\
\hline 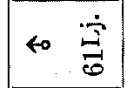 & 我栾 & \&o & 璌 & of 突 & <0 & «o 豈 & \&o: & \&o $\begin{array}{c}\dot{\vec{g}} \\
\mathrm{~g}\end{array}$ & of $\dot{5}$ & \&o $\frac{\dot{3}}{10}$ & to 客 & ro: & to \\
\hline 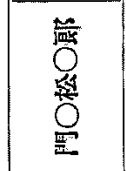 & $\begin{array}{l}8 \\
0 \\
8\end{array}$ & $\begin{array}{l}0 \\
\text { H } \\
0 \\
\text { If }\end{array}$ & $\begin{array}{l}0 \\
k \\
0 \\
0 \\
\text { 殹 }\end{array}$ & $\begin{array}{l}0 \\
0 \\
0 \\
\frac{1}{x}\end{array}$ & $\begin{array}{l}0 \\
11 \\
0 \\
\text { 影 }\end{array}$ & 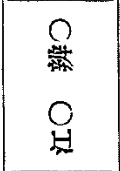 & 0 & 然 & $\begin{array}{l}0 \\
x \\
0 \\
\vdots\end{array}$ & \begin{tabular}{l}
0 \\
\multirow{2}{*}{} \\
0 \\
\multirow{2}{*}{} \\
04
\end{tabular} & 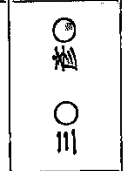 & $\begin{array}{l}\mathrm{O} \\
\mathrm{O} \\
\mathrm{O} \\
\mathrm{O}\end{array}$ & 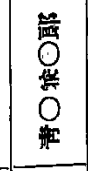 \\
\hline 䄈 & 아 & 声 & 羿 & 粱 & $\exists$ & 㖕 & $\ddot{J}$ & \pm & \pm & 疋 & 1 & $\stackrel{D}{0}$ & $\Rightarrow$ \\
\hline
\end{tabular}




\begin{tabular}{|c|c|c|c|c|c|c|c|}
\hline 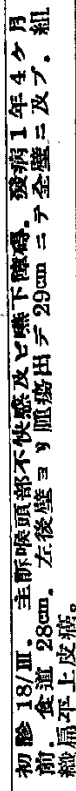 & 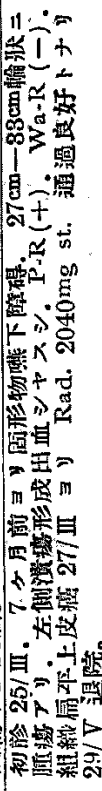 & 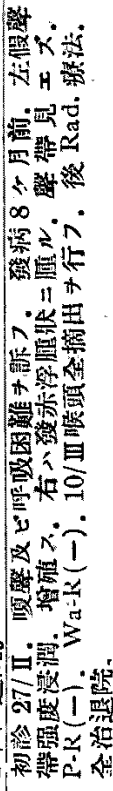 & 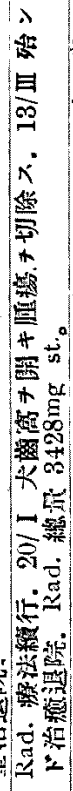 & 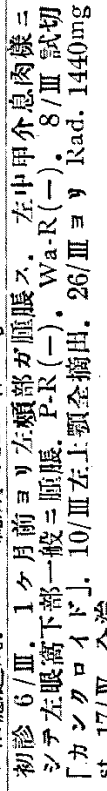 & 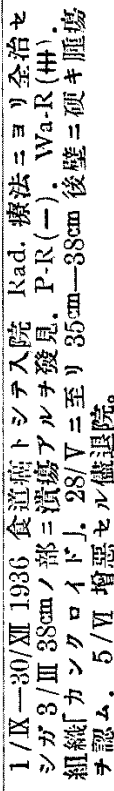 & 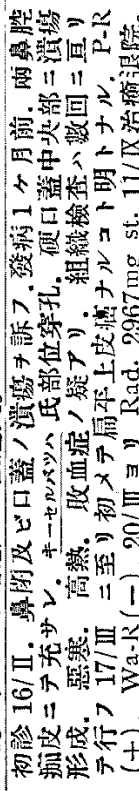 & 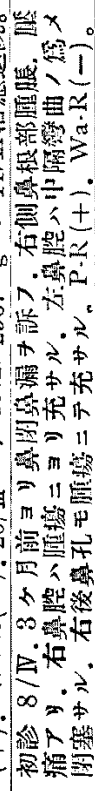 \\
\hline$H$ & $\begin{array}{l}E \\
+ \\
-\end{array}$ & - & $b$ & $\mapsto$ & $\begin{array}{l}E \\
\pm \\
+\end{array}$ & 目 & $\forall$ \\
\hline+ & + & + & + & + & + & I & + \\
\hline $\begin{array}{l}\text { कर० } \\
\text { कू } \\
1+\end{array}$ & $\begin{array}{ll}9 & 0 \\
+ & 5 \\
\dot{H} & \infty \\
+ & +\end{array}$ & $\begin{array}{l}\overrightarrow{0} \\
\dot{0} \\
+\quad+\end{array}$ & $\begin{array}{l}\text { :종 } \\
30 \\
+1\end{array}$ & $\begin{array}{ll}6 & 2 \\
0 & 2 \\
1 & +\end{array}$ & $\begin{array}{ll}9 & 8 \\
10 & 0 \\
+ & + \\
+ & +\end{array}$ & $\begin{array}{l}\stackrel{5}{0} 0 \\
+4 \\
+\quad+\end{array}$ & $\begin{array}{l}\text { 我是 } \\
0 \infty \\
+1\end{array}$ \\
\hline N & $\begin{array}{l}\text { N } \\
\stackrel{i}{H}\end{array}$ & $\begin{array}{l}0 \\
8 \\
\infty\end{array}$ & $\stackrel{\infty}{\stackrel{\infty}{\dot{m}}}$ & $\frac{\infty}{8}$ & $\begin{array}{l}8 \\
\dot{8} \\
\infty\end{array}$ & के & $\begin{array}{l}00 \\
0 \\
0\end{array}$ \\
\hline मू & 8 & \% & $\begin{array}{l}0 \\
0 \\
01\end{array}$ & की & $\stackrel{*}{*}$ & $\underset{8}{\stackrel{8}{0}}$ & $\begin{array}{l}\hat{0} \\
+\overrightarrow{0}\end{array}$ \\
\hline के & 薄 & 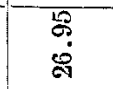 & ஓ. & 商 & ज़ & 它 & 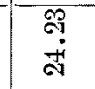 \\
\hline 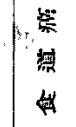 & 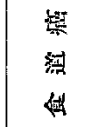 & $\begin{array}{l}\text { 嫼 } \\
\text { 器 } \\
\text { 紫 }\end{array}$ & $\begin{array}{l}\sqrt{1} \\
1 \\
4 \\
4\end{array}$ & 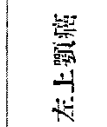 & 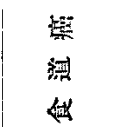 & 品 & 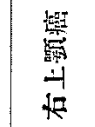 \\
\hline$\frac{1}{9}$ & 圈 & 具 & 昌 & $\begin{array}{ll}\text { 目 } \\
0\end{array}$ & $\frac{1}{8}$ & $\frac{1}{8}$ & $\frac{k}{\infty}$ \\
\hline का & to & so 空 & to & 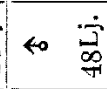 & to & \&o & 捾 \\
\hline $\begin{array}{l}0 \\
0 \\
0 \\
0\end{array}$ & 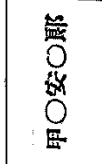 & 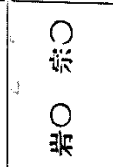 & $\begin{array}{l}0 \\
0 \\
2 \\
2\end{array}$ & $\begin{array}{l}0 \\
0 \\
0 \\
0\end{array}$ & 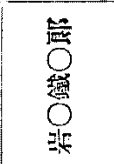 & $\begin{array}{l}0 \\
2 \\
0 \\
24\end{array}$ & 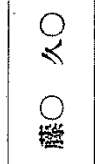 \\
\hline $\begin{array}{l}0 \\
0 \\
-7\end{array}$ & $\stackrel{*}{\varrho}$ & 曷 & $\stackrel{\mathscr{\varrho}}{\Omega}$ & $\sqrt{5}$ & 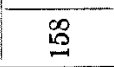 & : & $\stackrel{0}{0}$ \\
\hline
\end{tabular}

第二節 反㮣型，分粼二就テ

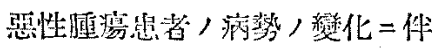

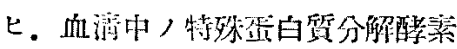

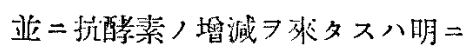

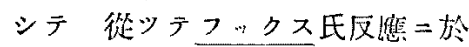
テモ血湔二癌「フィブリン」並に 正常「フ ブリン」フ扠へタル際

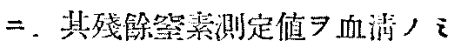
，場合二比スル時. 種々ナル増娍 型ヨ示スハ當然ナリ。

聚=兒玉教授ハた 96 型二分類 シ. 淇後辰谷川八10型=安睤ハ 7 型二分類七り。余八安增，分類七 ル第 4 型ハ二ッ, 型 7 含ムヨ以テ 之ヨ分離シ。フックス及フィルケ ンハゥゼン， indifferent 型、 又

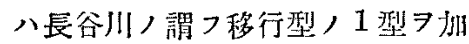
ヘラ次ノ如タ 9 型ニ分テリ。

第 1 型 對照タル血涪ノにノ殘 涂䇪素量卜癌「フィブリン」添加

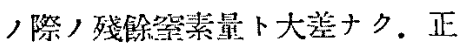
常「フィブリン」源加，際=於テ 破壤增扣 7 見儿瑒合二テ资犁的ナ ル反哕ナリ。

第 2 型 癌「フィブリン」港扠

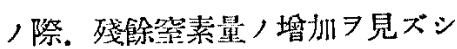
テ. 正常「フブリン」涩昐，際

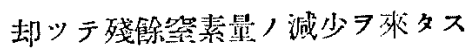
モノナリ。

第 3 型 癌「フィブリン」並= 正常「フィブリン」涯玑，際。共 殘餘雒素，減少 7 來夕スモ＝ シテフックス，所謂门免疫反㤰 型ナリ。

第 4 型 癌「フィブリン」添昍 
，際ニ八．殘餘烓素娍少ヨ來タシ，正常「フィ ブリン」添扠，際にハ大差ナキ場合ナり。

第 5 型 兩「フィブリン」添扠/際. 孰レモ

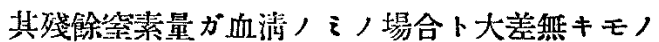
ナリ。

第 6 型 癌「フィブリン」涯加ノ際八殘権窒. 素量ノ減少习來タスモ．正常「フィブリン」八

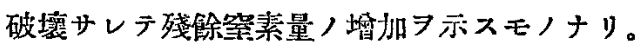

第7型兩「フィブリン」添加八際。共=同 程度，殘賖窒素燃加

第 8 型 癌「フィプリン」源㧈, 際. 增扣 7 見ルモ．正常「フィブリン」ヨ添㞦セルモノ

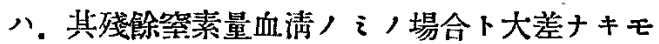
ノニテ. 正常反雄ナリ。

第 9 型 癌「フィブリン」添㧈ノ際二八殘集

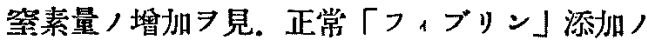
際逆ニ減少フ示スモノナリ。

以上ノ他二兒玉敩授二倣七，兩「フィブリン」添 扠／際共二殘餘喾素量增加スルモ. 正常「フィ ブリン」涯㧈ノ際ノ增加ガ. 癌「フィブリン」 添州ノ際ノ夫レョリモ大ナル場合ニハ. 型ノ上 ヨリ第 1 型卜第 7 型トノ結合セルモ，ト看做シ タท。

之等，各反應型，閒二八倘木無數ノ移行型アル 八勿諭ナルモ。 之等八其傾向二依り最モ近キ反 應型＝加フルコト、七り。

各型，例数及ビ比卒八第 2 表ニ示スガ如シ。

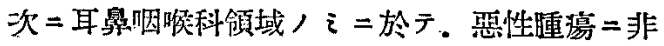
ザル事明トナリタル疾患 27 例，反應型八第 3

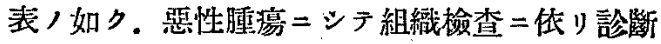
明トナリタルモノ 及ビ臨肽上明二惡性偅婸ト 確認セラレタルモ/ 第 4 表ノ如シ。
第三蒒 惡性腫湯發生部位卜

反應型

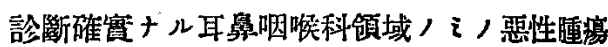
95 例 =於テ.え 反應型二類別スレバ第 5 表ノ如シ。發生部位ハ

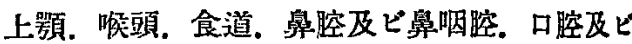
呐頭其他部位， 5 =區分セり。孰レモ第 1 型最

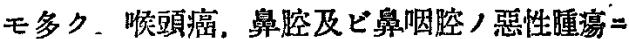
八數例ノ第 7 型 7 見. 食道癌二於テ八第 1 及比 第 7 型，混合型，多キ 7 見. 食道癌，1例 $(\mathrm{Nr}$. 146) =於テ正常反應型タル第 8 型ヨ示スヨ見ル 八注目スベキ所ナリ。又晚頭癌ノ1 例 (Nr.25) 二於テモ喉頭全剔出術後佾木頸部淋也腺二轉移 ヨ來タセルモノ二於テモ同㖨第1型7示セり。

第四節 第 $2.3 .4 ， 5$ 型 示シタル掟例二就テ

第 3 型ハフックス，所謂「免疫反應」型 $=$ シ テ.手術挠.「ラヂゥム」及ハ「レ」線療法」 途中ニアルモ/ 及ビ惡性腫㾿ナルモ比較的良性

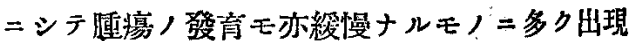
スルモノトサル。第 2 及ビ第 4 型モ後述ノ如ク 理諭上第 3 型二類似シ，以上， 3 型 $尹$-括シ 「免度反應」型ト名附クルモ差支へナキモノナ リ。又第 5 型モ後二述べル如り之等/反應型二 近似ナルモノナレバ，之等 4 型ヨ，一括シテ如何 ナル症例二出現セシカラ述ベントス。

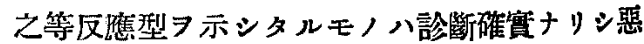

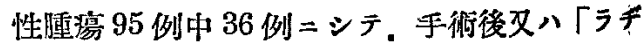
ウん」或ハ「レ」線治療經過＝アリシモノ19例。 之等ノ治療ヨ受ケザルモ。發病ヨリ，經過緩曼 シシテ比較的良性ナリト思ハレタルモノ8例 $(\mathrm{Nr} .4,12,94,110,125,130,149,152)=$. テ. 此中㘈頭癌 2 例 (Nr. 4, 149). 上顎癌 (N: 
籍 2 表

\begin{tabular}{|c|c|c|c|c|c|}
\hline 型 & $\begin{array}{l}\text { 癌「フ } \\
\text { ブทン }\end{array}$ & $\begin{array}{l}\mathbb{E} \\
71 \\
21\end{array}$ & 反雔 & 例数 & $\%$ \\
\hline 1 & \pm & + & + & 51 & 31.8 \\
\hline II & \pm & - & + & 17 & 10.6 \\
\hline III & - & - & + & 21 & 13.1 \\
\hline $\mathbb{N}$ & - & \pm & + & 9 & 5.6 \\
\hline V & \pm & \pm & + & 5 & 3.1 \\
\hline VI & - & + & + & 7 & 4.4 \\
\hline VII & + & + & $-(+)$ & 14 & 8.8 \\
\hline VII & + & \pm & - & 18 & 11.3 \\
\hline $\mathbb{X}$ & + & - & - & 6 & 3.8 \\
\hline $\mathrm{I}+\mathrm{II}$ & $H$ & \# & + & 12 & 7.5 \\
\hline & & & 計 & 160 & 100 \\
\hline
\end{tabular}

12.j) 及ビ舌癌 $(\mathrm{Nr}, 152)$ ）各 1 例八其後孰レ モ手術ニヨり臨牀上全治卜認メラレ。殊二喉頭 葛 1 例(Nr. 4)八術後 41 日目二フュッス氏反 應モ陰性7示スニ至リタルモノナリ(第 9 表)。 残り,9例ハ何等ノ治療ヨ受ケシコトナク，經 過モ緅慢ナラザリシモノナリ。

手術後刃ハ「ラデウム」或ハ「レ」線治淹經過 中二之等/反隹型 7 示セシ 19 例中. 臨林經過 㱍曼ニシテ比較的良好ナリト思ハレシモノ＝就 キテ見ルニ。摩街ノミア行ヒタルモ１例 $(\mathrm{Nr}$. 134)，手術後「ラヂウム」又八「レ」線习侀用 セシモノ4例 (Nr. 122, 129, 142, 156).「ラヂ ウム」或八「レ」線治療中ノモ，6例 (Nr. 92, $104,106,115,116,132)$ 計 11 例=之見. 其 他ノ8例ハ孰レモ「ラヂゥム」又ハ「レ」線治 瘵中ノモノナリシモ。其經過良好ナラザリシモ ノナリ。
第 3 表

\begin{tabular}{|c|c|}
\hline 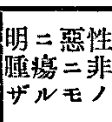 & 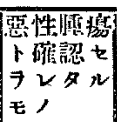 \\
\hline 4 & 86 \\
\hline 1 & 13 \\
\hline 3 & 13 \\
\hline \multirow[t]{3}{*}{1} & 5 \\
\hline & 5 \\
\hline & 3 \\
\hline 5 & 6 \\
\hline 8 & 2 \\
\hline 4 & \\
\hline 1 & 12 \\
\hline 27 & 95 \\
\hline
\end{tabular}

第五節 第 7 型 7 示シタル 往例 $=$ 就

第 7 型師チ癌「フィブリン」並二正常「フィ

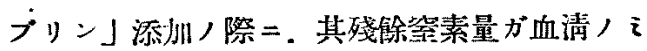
ノ場合二比較シテ兩者共 $=$ 同程度ノ筫加习示ス 反涊型ニシテ 160 例中 14 例即チ $8.8 \%$ こ 見タリ。

而シテ此中惡性揰澺＝非ズシテ他ノ疾息卜認よ ベキモ， 7 例アリ，其他，6例八明二惡性腫婸 フ證明シ得タルモノニシテ 其中 5 例 (Nr. 29, $41,47,61,72)$ 八治療經過中二發現シ．他 1 例（Nr. 149）八何等治療习受ケザリシモピル ケ一氏反應陽性ニシテ，反應检查賞時高熱持續

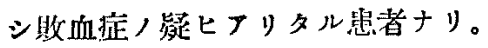

第六萿 第 1 型卜第 7 型ノ結合型二就テ 此反應ヨ示シタルモノ八全例中 12 例ニシテ

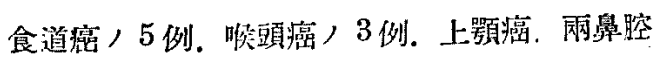
肉腫，上咽頭繊維肉腫及ど口蓋征桃腺癌/各 1 
第 6 嘞

\begin{tabular}{|c|c|c|c|}
\hline 型 & 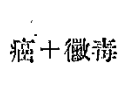 & 癌十絬核 & 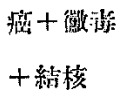 \\
\hline I & 3 & 5 & 2 \\
\hline II & & 3 & \\
\hline III & 1 & 1 & \\
\hline $\mathbb{I}$ & 1 & & \\
\hline$\nabla$ & 1 & & \\
\hline VI & & 1 & \\
\hline VII & & 1 & \\
\hline VIII & 1 & & \\
\hline $\mathrm{IX}$ & & & \\
\hline$I+\nabla I$ & 2 & 2 & 1 \\
\hline 計 & 9 & 13 & 3 \\
\hline
\end{tabular}

例ニシテ，他二岳膿瘍ナリシモノ１例アリタ リ、食道癌ノ5例ニアリテハ、「ラデウム」治療 中ナルモ，1例 (Nr. 138)，何等治瘵习受ケズ

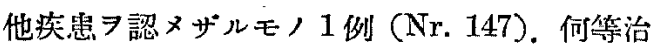
療要ケザルモピルケ一氏反箵(十)ナルモノ 1

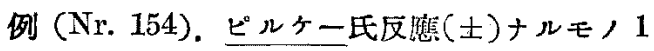
例 (Nr. 146)。食道癌トシテ「ラデゥム」治療 ニヨリ監牀的二全治卜認メラレタルモ。約 2 ヶ 月後再發シ。丛氏反應(卅)ナルモノ1例 (Nr.

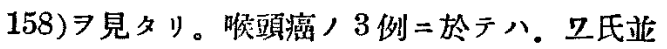

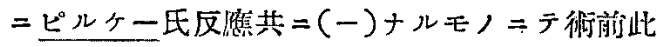
反應型 7 示 $*(\mathrm{Nr} .77)$. 喉頭全摘出術後約 1 ケ

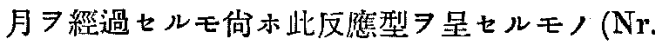
99).何等ノ治療モ受ケズ上述 2 反雇等檢查セザ リシモノ(Nr, 118) 备 1 例ナり。上顎癌， 1 例 (Nr. 7) 八何等治療䓅ヶシコトナキモピルケ

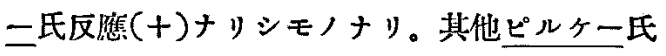

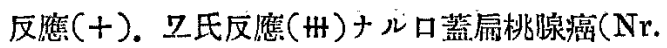

第 7 裴

\begin{tabular}{|c|c|c|}
\hline 徽 清 & 結 核 & 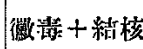 \\
\hline & & \\
\hline & 1 & \\
\hline & & \\
\hline & & \\
\hline & & \\
\hline & & \\
\hline \multirow[t]{2}{*}{2} & & \\
\hline & 3 & \\
\hline \multirow[t]{2}{*}{1} & $\mathbf{3}$ & \\
\hline & & 1 \\
\hline 3 & 7 & 1 \\
\hline
\end{tabular}

第 8 表

\begin{tabular}{|c|c|}
\hline 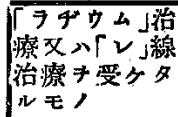 & 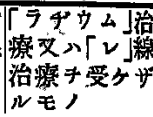 \\
\hline 3 & $33:$ \\
\hline 6 & 57 \\
\hline 7 & 6 \\
\hline 1 & 4 \\
\hline 3 & 2 \\
\hline 1 & 2 \\
\hline 2 & 4 \\
\hline 1 & 1 \\
\hline 3 & $9^{-}$ \\
\hline 26 & 69 \\
\hline
\end{tabular}

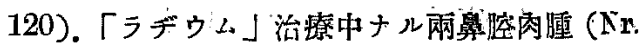
$60)$ 及ビ上咽頭繊維肉腫 $(\mathrm{Ni} .63)$ ）各 1 例 7 見タリ。

茅七節 他疾舁 7 合併七几惡性腫湯；

反應型二就宁

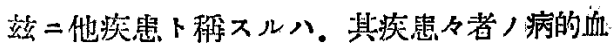
液「フィプリン」ト正常「フィプリン」トヨ用

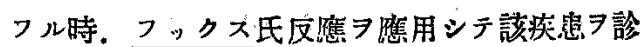
斷シ得ルモノニシテ 此中惡性㬴谤卜鑑別ヨ要 スル疾患ハ慢性疾患ニシテ主トシテ結㤥ト徽毒 ナリ

結核ト徽毒ト，明カナル病像ハ認メ得ザルモ。 ピルケ一氏反應及ビ血液，卫氏反應亚 $=$ 其類似 反應陽性ナルモノ八之等疾患，合件アルモノト 看做シ。”應型別＝表示スレバ第 6 表ノ如シ。

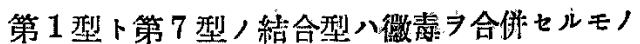
$=1$ 例. 結核 7 合併七ルモ，2例. 兩者习合傡 セルモノ 1 例ニシテ 微青ニテハ第 1 型多ク. 
縰ニテハ第 1 型及ビ第 2 型ノ多ク出現七ル 見几。

\section{第入㹂 他疾患(徽毒及ビ結核)}

卜反應型

惡性腫場ノ疑ヒラ以テフックス氏反應习行ヒ タルモ。後二至リ明二徽素又八結㤥卜喰斷七ラ レタルモノタ表示スレバ第 7 表ノ如シ。郎チ微 毒3例，結核 7 例，兩者 7 合侀七ルモ, 1 例 $=$ シテ。徽毒/ 3 例中 2 例八第 7 型 7.1 例八第 9 型ᄏ示シ. 2 例八口氏反應陽性／他＝喉頭亚 二硬口蓋ニ明カナル徽毒像 反應 $($ 曲) ナリ $(\mathrm{Nr} .21,45,127)$ 。結核ニテハ ピルケー氏反缻陽性ナリシモノ4 例アリテ。其 中 3 例 (Nr. 19, 89, 93) 八第8 型 7.1 例 $(\mathrm{Nr}$. 124）八第 2 型ヨ示シ。ピルケ一氏反淮陽性ノ けナラズ明ニ結核像ヨ證明シ得タルモノ八殘り / 3 例ニシテ總テ第 7 型タ示セり (Nr. 44, 140, 1E0)。雨疾患 7 合併セル1例 (Nr. 85) 八喉頭

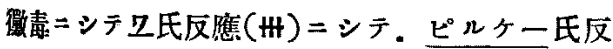
隹入(十)ナルモ他二何等ノ結核像八認メザリシ モノナリ。

第九蕒「ラヂウム级ビ「レ線放射， 反礁型二及ボス影響二就テ

瑟性嗹嗙ニシテ操血前「ラデゥム」又ハ「レ」 線台㙩习行ハザルモノト行ヒシモノト二就テ之 7 反應型別 $=$ 分類 スレバ第 8 表ノ如シ。此際 「ラヂウム」及ハ「レ」線治療フ受ケタルモ， シシテ探血前1ケ月以上ニ亘ルモ，入之等治療 ヨ受ヶザル部二加算セり。

「ラチウム」及ビ「レ」線治潦习受ケタルモ， 八第 2 . 第 3 、第 5 型等比較的多数 $=$ 現レ，受 ケザルモノニテハ第 1 型多シ。

邓「ラデゥム」及ビ「レ」線治療縃過二件フ反
憵型ノ曫化二就キテハ第 10 節 所アルペシ。

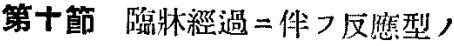
變化 $=$ 就

臨片經過中 3 回以上フックス氏反應 7 检沓七

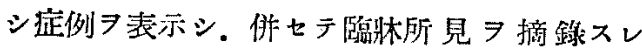
尺. 第 9 表 $コ$ 第 16 表二示スガ如シ。

第 9 表並二第 10 表ニ示スモノ八读頭癌及ビ上 顎癌ノ各 1 例ニシテ就レモ根治的手郷フ受ケシ

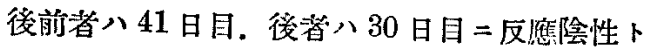
ナリ臨牃的二モ完全治瘺卜認メラレタルモ，前 者八約 1 年後. 後者八約 7 万月後 $=$ 再檠 7 來夕 シ．爾学共再ビ反應陽性フ示スニ至レッ。 第 11 表二示ス莚例八初メ第 6 型ヨ示シタルモ 後 3 回共第 7 型 $习$ 示七リ。

第 12.13.14表二示ス 3 例八敦しモ「ラヂウム」 或八「レ」線治療习行ヒタルモノニテ. 其經過 二伴フ反應型 7 見ル二，第 2 、第 3 型等，「炛 疫反應」又心之ト類似，反應型二至几以前=。 第 7 型. 及第 1 型卜第 7 型卜 結合型 7 示 ア見タリ。

第 15. 妓ビ第 16 表＝示ス 2 症例八臨桨經過中 何時モ。「冤度反應」又八之二類似；反應型 シ。輹牀經過モ極メテ良好ナリシモノナリ。

第 9 表

北文○ 今 $52 \mathrm{Lj}$. (Nr. 4, 24. 135)

\begin{tabular}{|c|c|c|c|}
\hline & $\begin{array}{c}\text { a (12/Vil ) } \\
1935\end{array}$ & $\begin{array}{c}\mathrm{b}(2+/ \mathrm{X}) \\
1935\end{array}$ & $\begin{array}{c}\mathrm{c}(18 / \overline{X I}) \\
1936\end{array}$ \\
\hline & \multicolumn{3}{|c|}{$\mathrm{R} \cdot \mathrm{N}(\mathrm{mg} \%)$} \\
\hline 血 清 $1 \mathrm{cc}$ & 36.11 & 26.41 & 26.85 \\
\hline 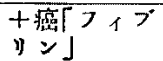 & $34.9 t$ & 28.29 & 19.69 \\
\hline $\begin{array}{l}\text { +正管「7 } \\
\text { プリ }\end{array}$ & 33.94 & 26.81 & 22.45 \\
\hline 物 & + (III) & $-($ VIII $)$ & $+($ III $)$ \\
\hline
\end{tabular}




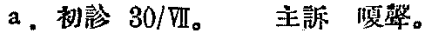

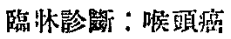
病理組䋘：䑷平上皮癌

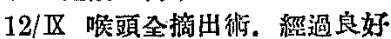

b. 呢䫓全摘後 41 日. 經過良 $21 /$ XI 全治退院。

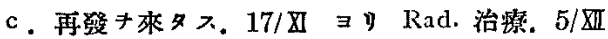
急二一般狀態惡化死亡フ。

$$
\text { 第 } 10 \text { 表 }
$$

䅘 ○平 今 $56 \mathrm{Lj}$. (第 1 表 Nr. $7,19,81$ )

\begin{tabular}{|c|c|c|c|}
\hline & $\begin{array}{c}\text { (22/Vii }) \\
1935\end{array}$ & $\mathrm{~b}(5 / \mathrm{X})$ & $\begin{array}{c}c(15 / \mathrm{IV}) \\
1936\end{array}$ \\
\hline & \multicolumn{3}{|c|}{$K \cdot N$ mg $\%$} \\
\hline 血 清 $1 \mathrm{cc}$ & 33.74 & 37.75 & 27.23 \\
\hline 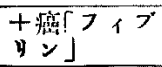 & 37.02 & 42.85 & 27.61 \\
\hline $\begin{array}{l}\text { 十正第「フ } \\
\text { ブリン }\end{array}$ & 39.77 & 37.87 & 34.83 \\
\hline 刵 & $+(I+\mathbb{I I})$ & $-(\mathrm{VII})$ & $+(I)$ \\
\hline
\end{tabular}

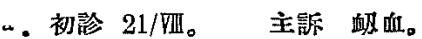

$$
\text { 發病萑：1年 } 2 \text { 名月前 }
$$

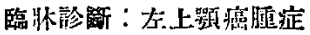

病理組緋：原平上皮癌

6/IX 左上颚全切除背

b. 術後 30 日全治退院。

c. $23 /$ III 1936 ヨy Recidiv 起シ來タル。

$$
\text { 第 } 11 \text { 表 }
$$

\begin{tabular}{|c|c|c|c|c|}
\hline & $\begin{array}{r}a(16 / \mathbb{X} X \\
1935 \\
\end{array}$ & $\mathrm{~b}(6 / \mathrm{XI}$ & c (21/XI & $\mathrm{d}(12 / \mathrm{XII})$ \\
\hline & \multicolumn{4}{|c|}{$\mathrm{R}-\mathrm{N} \mathrm{mg} \%$} \\
\hline 血清 1 ca. & 34.13 & 27.77 & 30.11 & 27.16 \\
\hline $\begin{array}{l}\text { †癌フィ } \\
\text { プン」 }\end{array}$ & $31.0 \pm$ & 32.77 & 38.12 & 32.12 \\
\hline $\begin{array}{l}+ \text { +正盀厂 } \\
1 フ ゚ ン\end{array}$ & 40.76 & 32.23 & 38.85 & 31.36 \\
\hline 刵 & $+(V)$ & $+(\nabla I)$ & $+($ VII $)$ & + ( DII) \\
\hline
\end{tabular}

山○鬿○郎 今 $63 \mathrm{Lj}$. (第 1 表Nr. $12,29,41,47$ )

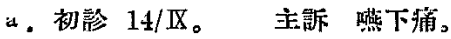

發 病：1年 2 ケ月前

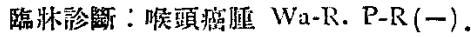

病理組䖻：癌蕾!

$3 / X$ 筷嘼全摘出術

b, c, 絕副順調。

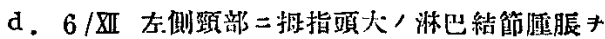

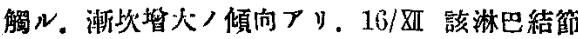
摘出，摘出漂本病理組織學的檢省、「カンクー

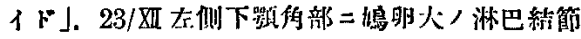

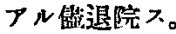

\begin{tabular}{|c|c|c|c|}
\hline & $\begin{array}{c}\text { a }(2 / \mathrm{XI}) \\
1935 \\
\end{array}$ & $\begin{array}{c}\mathrm{b}(12 / \mathrm{II}) \\
1935\end{array}$ & $\begin{array}{c}c(21 / \text { III }) \\
1936\end{array}$ \\
\hline & \multicolumn{3}{|c|}{ R-N mg $\%$} \\
\hline 血 清 $1 \mathrm{cc}$ & 30.10 & 22.17 & 21.32 \\
\hline 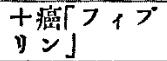 & 27.42 & 29.39 & 19.61 \\
\hline 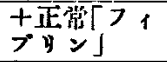 & $33: 00$ & 28.85 & 17.93 \\
\hline 物 & $+(\mathrm{VI})$ & $+($ VII $)$ & $+($ III $)$ \\
\hline
\end{tabular}

第 12 表

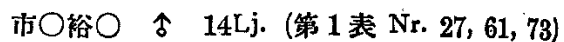

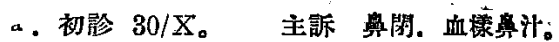

登痛：2 月月前

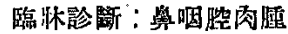

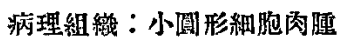

體 重: $35.600 \mathrm{~g}$

b. $27 /$ XII-10/II 43回／「レ」樂深部療法(3000).0 r)。

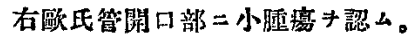

$$
\text { 體 重: } 37.900 \mathrm{~g}
$$

c「レ」線深部蹬法。 $4 \mathrm{X}$.「ラダウム」療法(4800 mg. st.):

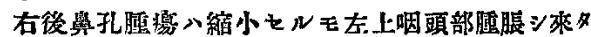
y右攻部淋巴腺二签移キ生ズ。

$$
\text { 壖 重: } 40.500 \mathrm{~g}
$$

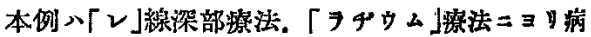

\begin{tabular}{|c|c|c|c|}
\hline & $\begin{array}{c}a(14 / \mathrm{I}) \\
1936\end{array}$ & $\mathrm{~b}(12 / \mathrm{II})$ & c $(4 /$ III $)$ \\
\hline & \multicolumn{3}{|c|}{$\mathrm{R}-\mathrm{N} \mathrm{mg} \%$} \\
\hline 血 清 $1 \mathrm{cc}$ & 33.45 & 29.79 & 31.47 . \\
\hline +癌 $フ ォ 7$ & 33.29 & 35.30 & 31.58 \\
\hline $\begin{array}{l}\text { サ正常「フィ } \\
\text { ブリシ」 }\end{array}$ & 38.90 & $\begin{array}{r}37.87 \\
\end{array}$ & 28.39 \\
\hline 制 & $+(I)$ & $|+(I+V I)|$ & $+($ II) \\
\hline
\end{tabular}

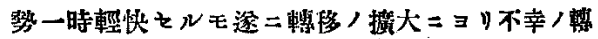
趾キトル(5/式)。

第 13 表

竹○九○ \& $62 \mathrm{Lj}$. (第一表 Nr. $52,60,66$ )

a. 初龍 $11 / \mathrm{I}$ 。

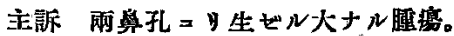

發 病： 1 年前

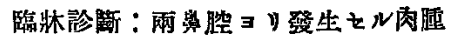

病理組纖：多型細胞闪画

b、「ラヂリム療法キ每日行ヒ. $154.0 \mathrm{mg}$ std. 挠

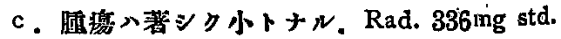


第 14 㤗

森O幸O \& $40 \mathrm{Lj}$. (第 1 表 Nr. $55,63,72,92$ )

\begin{tabular}{|c|c|c|c|c|}
\hline & $\begin{array}{c}(1 / \text { II }) \\
1936\end{array}$ & $\mathrm{~b}(19 / \mathrm{II})$ & c $(21 /$ III $)$ & $d(17 / \nabla)$ \\
\hline & \multicolumn{4}{|c|}{ R.N mg \% } \\
\hline 血清 $1 \mathrm{cc}$ & 28.19 & 28.48 & 27.42 & 24.14 \\
\hline 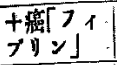 & 30.10 & 32.77 & 34.60 & 22.62 \\
\hline 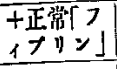 & 36.14 & 35.58 & 32.23 & 22.45 \\
\hline 制定 & $+(I)$ & $\left(\begin{array}{c}+ \\
(I+V I I)\end{array}\right.$ & $+(\mathrm{VII})$ & + (III) \\
\hline
\end{tabular}

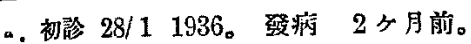

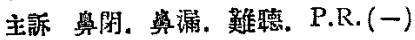

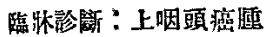

病理組䋨：Fibrosarkom.

b.「ヨチ゚ム」瘦法行フ (Ra.736ng st.)。

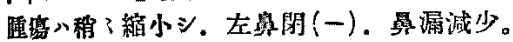

體 重: $46.000 \mathrm{~g}$

c.「ラヂム」蹽法キ續行 (Ra. $1686 \mathrm{mg}$. st.)。

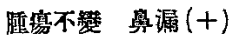

怔重 $: 38.100 \mathrm{~g}$

d.「フヂウム療法キ續行 (Ra. 3384mg st.)

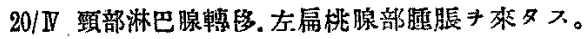
$11 / V$ 顥部淋巴腺轓移八摘出 $キ$ 行フ。

骴 重 $45.800 \mathrm{~g}$

第 15 表

坂○煡○ f $43 \mathrm{Lj}$. (Nr. 116, 132, 156)

\begin{tabular}{|c|c|c|c|}
\hline & $\begin{array}{c}\text { a }(28 / \mathrm{IX}) \\
1935 \\
\end{array}$ & $\mathrm{~b}(17 / \not \mathrm{XI})$ & $\begin{array}{c}\text { c }(13 / \text { III }) \\
1937\end{array}$ \\
\hline & \multicolumn{3}{|c|}{$\mathrm{R}-\mathrm{N} \mathrm{mg} \%$} \\
\hline 血清 $1 \mathrm{cc}$ & 30.83 & 31.47 & 31.90 \\
\hline 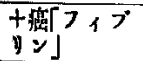 & 28.69 & 28.49 & 32.56 \\
\hline $\begin{array}{l}\text { 十正常>1 } \\
\text { フ十」 }\end{array}$ & 25.74 & 26.76 & 31.68 \\
\hline 物 & $+($ III $)$ & + (III) & $+(\nabla)$ \\
\hline
\end{tabular}

“. 初获 10/X 1936. 昭和 7 年10年 (1932) 上類嵒

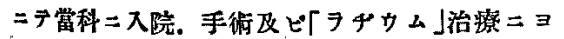

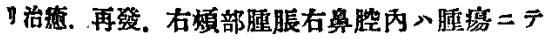

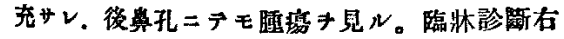

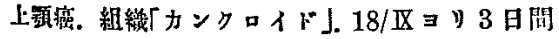

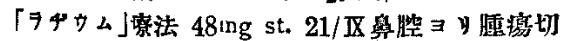
除。

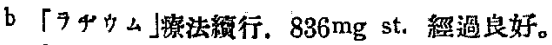

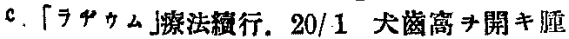

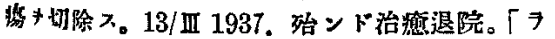
ナカム」總最 $3428 \mathrm{mg}$ st.
第 16 丧

高 ○文○ 今 $39 \mathrm{Lj}$. (Nr. 125, 134, 142)

\begin{tabular}{|c|c|c|c|}
\hline & $\begin{array}{c}\mathrm{a}(29 / \mathrm{X}) \\
1936\end{array}$ & $\mathbf{b}(17 / \mathrm{XI})$ & c (21/XII) \\
\hline & \multicolumn{3}{|c|}{ R-N mg $\%$} \\
\hline 血 清 $1 \mathrm{cc}$ & 38.51 & 44.90 & 36.50 \\
\hline 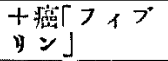 & 30.62 & 44.15 & 36.75 \\
\hline $\begin{array}{l}\text { †正常フィ } \\
\text { プリ」 }\end{array}$ & 40.35 & 41.17 & 25.56 \\
\hline 物 & $+(\mathrm{IV})$ & $+($ II $)$ & $+(I I)$ \\
\hline
\end{tabular}

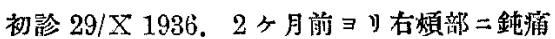

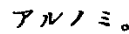

他學的所見ナシ．P-R(士)，村田氏反鷹(十)。

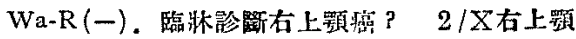

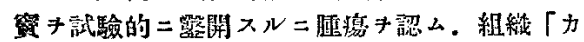
ンクロイド」。

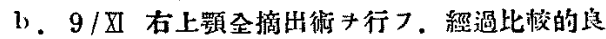

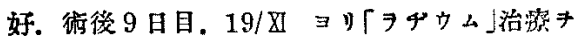
始么。

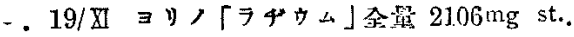
臨将上全治トシテ退院。

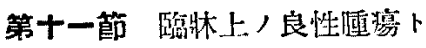

$$
\text { フ・クス氏反雇 }
$$

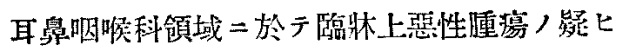
アリ後二至リ良性腫瘄ト認メラレタルモノ及ビ

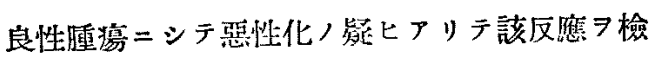
シタルモ，7症例アリタリ。其中 3 症例 $=$ 就キ テハ打後 2 回，反應检查 7 行ヒタル二訨り．反

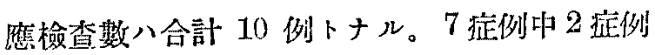

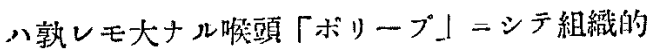
二惡性化 7 認入得ズ. 1 症则(Nr. 62, 71) =テ

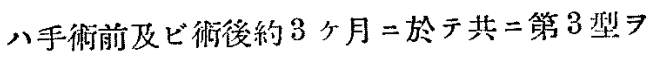
示シ. 他， 1 症例 $(\mathrm{Nr} .98,107)=$ テハ術通第 4 型 7 進後 6 月

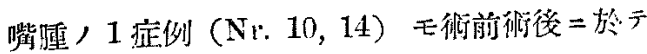
第 1 型卜第 7 型, 紹合型及ピ第 3 型 7 示セり。

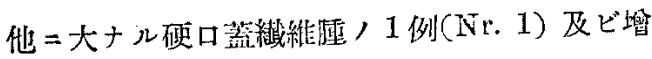
殖極メテ盛ニシテ肉腄 


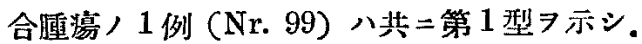
肺結核 7 合欮七几下咽頭後壁，乳踭腫，1例 (Nr. 140) 八第 7 型 7 . E大ナル鼻中隔堹骨瘇 ，1例(Nr. 143) 八正常反應郎于第 8 型 7 示 $七$ リ。

即チ 7 症例 /中 5 症例 =癌反應陽性 $コ$ 示シ。 2 症例 $=$ 陰性 見タリ，又检查数 10 例中 7 例八 陽性ニシテ 3 例八陰性ナリ。

陽性反應 $\exists$ 呈シタル 5 症例二就キ昭和13年 2 月 其遠隔成緽 $コ$ 葉書 $=ヨ ル$ 問合七 $=ヨ リ$ 調查七ル 二喉頭「ポリープ」(Nr. 98, 107). 喉頍乳嘴腫 (Nr. 10, 14). 軟口蓋混合腫漟 (Nr. 99)， 3 征 例八何等ノ症彇ナク全治ト認ムペキモノニシテ 他，2症例八返事ナキ䉆又逗隔成績不明ナリ。

\section{第十二笁 的確率＝就テ}

余ノ行ヒタル反應檢查數ハ 160 例 =シテ. 其 中第 7 型ヨ示シタルモノ 13 例厂リ。之等, 13 例八第 5 節二示スガ如ク，他疾㭧ナリシモ/ 7 例ニシテ 殘りノ6 例八瑟性腫瘍ナリ。其中 5 例八治療經過中二發現シ 1 例八何等治療 7 受 ケザルモ，ピルヶ二氏反應陽性ニシテ．高熱持 續シ敗血症フ思ハシメタル症例二現レタリ。此 反隹型，的確率

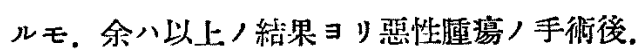

「ラデゥム」及ハ「レ」線等ニヨル治療經過中

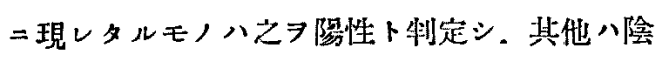
性卜制定スル事ト七り。

160 例中癌卜診斷七ラレタルモ，123 例 $=$ テ. 其中癌反虑

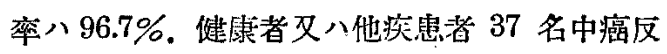
應习呈シタルモ，9 例ニシテ其的確率ハ $75.7 \%$ ナリ。即チ 160 例中相反スル反應 7 呈シタルモ , 13 例ニシテ. 全體，的確率八 $91.9 \%$ リ。
次 $=160$ 例中耳鼻咽喉科項域， ／资患=シ.テ 然壬他/臨林的所見. 試驗切片檢查.「儿一線检 㚗等二依り確賽＝診断セラレタルモ，122例二 シテ. 其中惡性腫瘍 95 例中相反スル反應习是 シタルモノ 3 例 =シテ其的確率ハ $96.8 \%$ リ。 正常及八他疾患ナルモ，27 例中陽性反痽 7 呈 シタルモノ 9 例 =シテ. 其的確率へ 66.7\%+リ。 郎チ 122 例中相反スル反應 7 呈七シモ，12 例 ニシテ全體ノ的確弯ハ $90.2 \%$ リ。

\section{第 四 票}

\section{總 括 並二考案}

1926年フックスハフロインド及カミーネル.

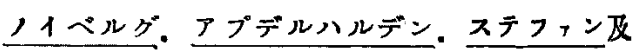
オ一ル等ノ研究淡靕 $\ni$ 基礎トシテ蛋白䯤タル 「フィブリン」ト血清ト，關孫二就キ. 氏/改 良七ルバング，「ミクロキールダール」變法卜 アプデルハルデンノ透所法トヨ用ヒテ．馬。山 羊. 羊等ノ動物ノ血液「フィプリン」ト夫等野 物ノ血清トア混合睬化セシメタルモノ二就キ。 定量的二殘俆学素量ヨ测定シテ精密ナル多数， 實驗成縜 $コ$ リ（1 血清八自己卜同種族/動物 ノ「フィブリン」八分解セヌガ.（2)他種族 動物ノ「フィプリン」ア分解スト云フ事富並二 夫等八全り醳素作用二據ルモノナル事习發見七 リ。亞イデ若シ惡性腫㾴が發生シタル際ニ八病 患省ノ「フィブリン」八癌患者ノ血清=ヨリ作 用セラル、ヤ否ャフ試驗セント企テ. 先ツ教腫 馬血清卜癌腫馬血液「フィブリン」ト=就テ上 述ノ方法 7 用ヒテ梄驗シタル結果ハ(1)癌腫馬 血清八癌腫䮡血液「フィプリン」=作用セザル モ. (2)正常馬/血液「フィプリン」二作用ス ルコトラ知リタリ。 
聯二於テ䫁驗方法

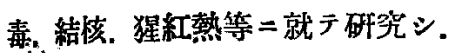

(1). 正常血清八正常血夜「フ・ブリン」=ハ 作用せズト踓モ病的血液「フィプリン」习破 壞ᄌ。

(2). 病的血清八同種疾患ノ血液「フィプリン」 トハ作用セザルモ. 正常血液「フィプリン」並 二他種次患ノ血液「フィプリン」アバ分解ス。 ト云つ事實习發見シ.「フィブリン」ニ八特殊酵 素夕ル抗元/樶着サレ居ルモノト推論セリ。此 發見へフっクス氏藻血清反應，礎石ニシテ 偉 犬ナル發見ト云フペキナり。

令正常「フィブリン」並=癌「フィブリン」 用七テ該反應习检查セン二.上述ノ理諭ヨリン ラ被检血清ガ正常ナル場合ニ八，癌「フィブリ ン」ヨ破壞シテ. 殘稌窒素量, 增加ヨ見ルモ。 正常「フィブッン」八何等ノ破壞ヨ受ケズ. 從 ッラ线餘究素量，䁌娍ナキ筈ナリ。次二被检血 清が癌患者血清ナル場合二八. 反對二癌「つィ ブリン」八破壤セズ. 正常「フ・ブリン」ヨ破 竄スルモノナリ。又上述ノ如キ他疾患ナル場合 シ八. 正常「フィブリン」椪二癌「フィプリン」

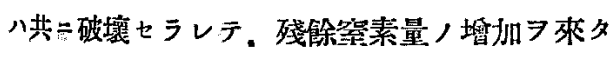
スペキナリ。郎チ之等/ 3 反應型八以上/理諭 二正確ニ一致シ定型的ナルモノナリ。

然ル二該反應八腫湯，保護这物タル酵素(抗元) 卜抗酲素（抗體）卜ノ作用二基クモノニシテ. 之等ノ塯減ニョリ. 種々ナル反應型ヨ示ス八常 然/事ト云フベシ。フっクスハ1926 年該反雇 檢查中癌㭧省血清ニシテ. 正常「フィプリン」

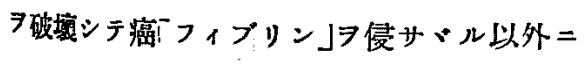

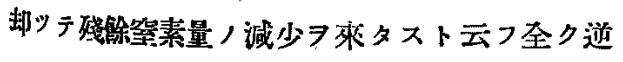

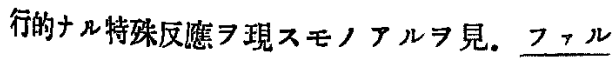

ケン八ウゼント共ニ「デフテリー」及ビ破匴㼙 ノ毒素及ビ抗毒素トア試驗管中ニテ混ジタルモ ノ 724 時間 $40^{\circ} \mathrm{C}=$ 保チタ儿挠. $2.5 \%$ 三監化 醌酸ニテ沈澱セシメ．其滤液ニッキ殘俆蜜素量 ア测定シ，(1)毒素及ビ抗毒素トア混ジタルモ 人、殘餘等素量ハ減少ス。(2)此毒絜及ピ抗毒 素, 作用八嚴密ナル特異性 素卜抗毒素卜人結合 $=ヨ$ 蛋白質 ノニシテ。各々賞量 諭二到達シ. 少ホ更ニ「ヂフテリー」毒素习有 スル婜血清ト「「゙゙フテリー寃度血清ヨリ作り タル「フーブリン」トフ混合瞕化セシメタルニ 殘餘觉素量 消失 $フ$ 招クラ見タリ。 次イデ 1932 年フックスハ「「フィブリン」ハ血

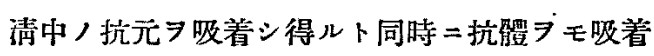
シ得ルモノンシテ抗元ヨ有スル「フィブリン」 ガ特異ナル抗艋ヨ有スル血清卜机合スル時. 抗

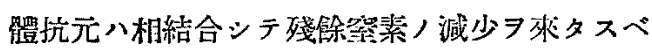
シ。此現象八毒素ト夫レニ對スル抗毒素トガ試

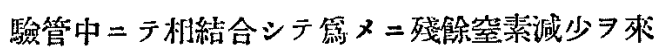
タストー般ナリト述ベタリ。而シテ該反應型习 示ス患者八治療，結果病势頓挫シテ㣻疫，狀態 ニアルラ以テ所謂「炛疫反應」ト名ジタリ．

斯ク，如キ反應型八以後多クノ學者 $=ヨ$ リ認メ ラレタル所ニシテ. 此反應型タ示スモノ八隐後 比較的良好ナルモノト解セラレタリ。

然レドモ此反應型，發現機轉二關スルフックス ，以上，說明ハ不充分ニシテ。氏ノ說明セシ如 ク「フィブリン」二吸着セラレタル抗元が特異 的二血清中，抗能卜結合スル事二作ツテノミ殘 稌犖素ノ娍少ヨ來タスナラパ. 癌りフィブリン」 添加ノ際 モ. 正常「フィブリン」添拟ノ際ニハ抗元 
セザルシ依り抗體ヨ吸着セシムル能ハズシテ何

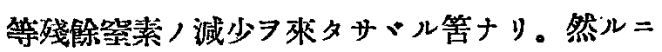
事實ハ之二反シテ正常「つィブリン」添加ノ際 ニモ癌「フィプリン添加ノ場合卜同樣殘墟掌素 ノ減少來タスモノアルノ゙ナラズ. 癌「フィ プリン」添加，際=何等ノ增減ナクシテ - 正常

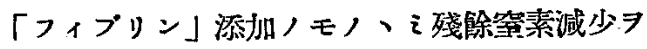
來タス例二屚 : 遭遇スルモノナリ。

抑々癌「フィブリン」=ハ抗體. 抗元ノ孰レガ 吸着サレ居ルモノナリヤ二就テハ。初メフック ス八抗元（吸着サル、モノト解シ. 後抗元 えナラズ抗體ヨモ吸着サレ居ルモノト解釋シタ ルモ．其詳細ナル說明ニハ言及セザリキ。之二 於テ昭和 10 年長谷川及ビ安增八肉腫家鬼血清 及ビ所謂「㘪度反應」习呈セル癌患者血清/限 外滤液二就キ詳細ナル研究ヨ遂ゲタル結果. 癌 「フィブリン」ニハ主トシテ分子大ナル抗體吸 着七ラレ. 分子小ナル抗元，吸着八僅少ナリト ノ結諭二達シ。長谷川八正常「フィブリン」添 加, 際二於テ殘俆塋素，減少 7 見儿八. 血淸中 ノ過剩ナル抗體ガ該「フィブリン」表面二吸着 サレテ起ル殘賖窒素ノ減少ガ.該「フプリン」 ヨ分解七ントスル酵素作用 $コ$ 相殺シテ尚木賖リ

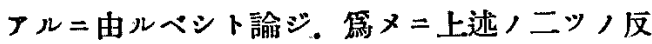
應型モ亦可能ナリト述べタリ。

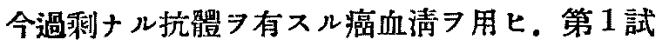

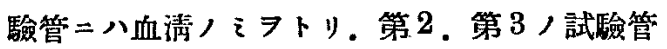
ニ八夫々癌「フィブリン」並＝正常「フィプリ

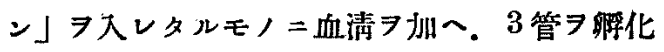
セシムル時八次ノ $2-3$ ，事象が可能ナルベシ。 第 1 試駿管中二八抗元卜過剩ナル抗體卜ノ共存 ニョリ. 前述ノ毒素及ビ抗毒素結合卜同怺=抗 元抗體ハ相結合シテ分子大トナり。三監化醋酸
=テ沈澱セラルベキモノラ形成スベシ。然レド モ此現象八第 2 . 第 3 試驗管中二於テモ可能二

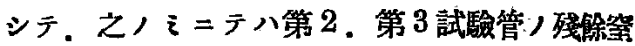
素量ガ第 1 試驗管ノモノニ比シ減少 7 來夕サ。 ルナリ。第 2 試驗管中ニテハ主二抗體 7 吸着七 ル癌「フィブリン」ハ佾木䋐分ノ抗體 シモ吸着 シ得ルコトアルペク．之等吸着七ラレタル抗貫 八血清中ノ抗元ト；結合モ亦可能ナルベシ。篇

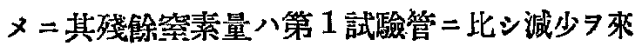
タス事アルベシ。第 3 試驗管=在リテハ. 正常 「フィブリン」ニヨル血清中ノ過剩/抗䯏呂着 及ビ其抗體卜血清中，抗元／絬合等二体り殘俆 窒素量娍少习棑タスモ. 其量が. 抗元 $\triangleq \exists ル$ 「フィブリン」分解ノ結果生ズべキ殘俆毠素，

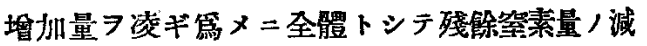
少ヨ桃タスコトアルベシ。斯クシテ第 2 . 第3 試驗管ノ殘餘空素量が第 1 試驗管ノ夫レ 減少 7 來タシタルモノ八第 3 型ニシ்フュクス ，所謂「免疫反應」型ナり。

而シテ第 2 試驗管二於テ吸着現像僅少ナルカ又

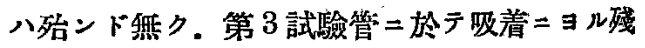
㮣空素量，減少ガ.「フィブリン」分解二依儿殘

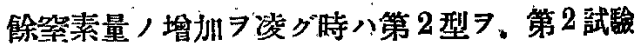
管/吸着現象影著ナルモ，第 3 試驗管/昨着卜 分解，作用量ガ相牛スル時八第 4 型习示スナ 1).

1931年キャドネス及ウ*ルフ Cadness B.H.E. u. C.G.L. Wolf 八直腸渻，1例=於テ「ラヂ ウム」(量不明) $\ni$ 用ヒテ 3 時間後二八該㭧者血 清，蛋白質分解作用八全ク停止シ. 20日間持續 スルラ見タリ。其後1932 年フォルケンハウゼン Falkenhausen M. v。 及コックススハラヂ

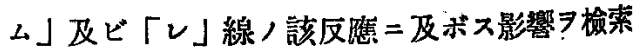


中正常「フィブリン」並二癌「フィブリン」添

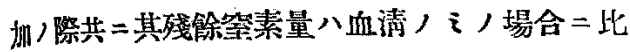

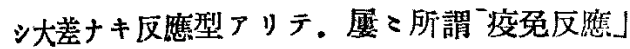
型現ス前二出現スルラ見. 其制定二虽り (土).

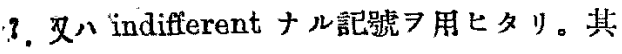
後長谷川八「要疫反應」二入ル前入八「桑疫反 應」ヨリ正常反應二移行セントスル際二發現ス ベキモノナリト述ベタリ。此反應型八第 5 型二 シテ，第 2 試驗管，吸着現象殆ンドナク 第 3 陚酸管，吸着卜分解卜が相牛バスル篇二出現ス ルモノニテ侗ホ癌ノ存在ア示スモノナレバ （十）ト刵定スベキモノナり

以上４反應型八敦レモ，陽性反應ナルモ。抗 體過剩ナル時二出現スルモノナリ。

次二癌「フィブリン」添加ノ際=殘馀空素量， 娍少习柬タスモ。正常「フィブリン」添加，際 八其增加 象八起ルモ。第 3 試䮑管ノ分解が吸着习凌グ篇 $メ=$ 出現スルモ）二テ矢張り陽性反應ナリ。

次二陰性反雇，各型二就キ考察セン二，正常反 䈍夕第 8 型二就キテ八 其發現機轉二說明 7 汯フベキ要ナシ。

瘟並二正常「フィブリン」ヨ共二破藵スル反應 型へ先二述べル如ク他疾患殊=徽毒卜結㤥， 場合二現レルモノニテ 之等他疾㭧患者八血清 中二特殊蛋白質分解醳素习有シ。 之が网「フ、 プリン」ラ破壤スルハ當然ナリ。然ル二余八琵 性䧉富ニシテ該反雇型ヨ呈シタルモ，6例 タルハ注目スベキ事ニシテ其發現機轉二就キテ 八後二考察スベシ。

次二輑「フィプリン」八破燷スルモ正常「フィ フリン」添加ノ際二減少フ桼タス反應型モ他疾

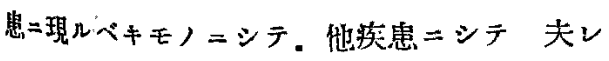

二特異ナ儿抗䯤多量二生遥サレ，所謂他次患，

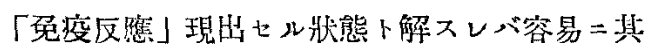
發現機轉フ說明シ得ベシ。

以上反隹ノ型 79 型二分チテ其發現機轉

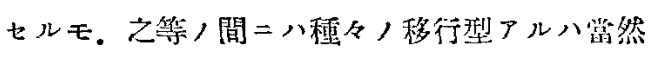
ナリ。

抑々反應型，分類二就テ八昭和 10 年兒王教授 八反應陽性ナル場合 74 㤠二陰性ナル場合 72 型 $=$ 分類シ. 長谷川八之 710 型二分類シ. 安 增ハ 7 型二分類七り。余八之等諸氏ノ反應型 7 參考トシ 以上 9 型二分類シ. 更二兒玉敎授= 倣ヒ型，上ヨリ第 1 型ト第 7 型卜，結合型 7 扣 フルコトセリ。

生简二惡性腫癔卜他種疾忽トガ同時二存在スル

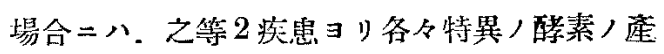
生アルベク，之等二對シテ生䯤い夫特殊ノ抗 酵素フ以テ報コベキハ鲎然ニシテ 之等酵素及

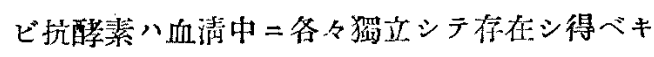
事玉推測シ得ル所ナリ。斯クノ如キ酵素立二抗 酵素フ有スル血清习癌並二正常「フィブリン」= 添加シデ㭌化せシムレバ雨「フィブリン」共ニ 破壊ア被ルハ明ナルモ．癌「フィブリン」八他 疾患, 醅素ニヨリ破燷サル、ノミナルニ反シ。 正常「フィブリン」八癌並二他疾忽八酵素二ヨ リ破壇サル、故二正常「フィブリン」添州ノ際

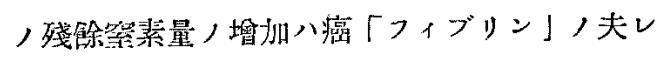
一比シテ大トナルベキナり。然レ共. 痘反應型

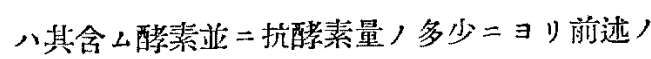

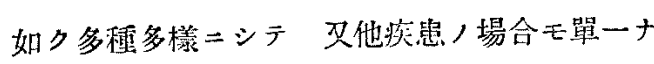
ラズ。之等，結合モ思考シ得ル所ニシテ必ズシ

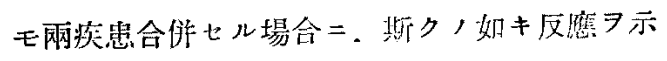
スモノトハ隄ラザルナリ。

余，行ヒタル 160 例／反管型／分類八第 2 表二 
示ス如クニシテ，百分率モ安增ノモノト大同小 異ナリ。

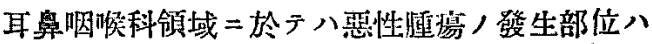
殆ンド肉眼ヨ以テ直接刃八間接二見得ル所ニシ

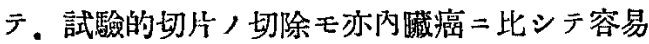

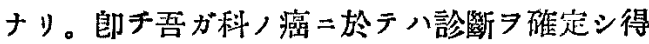

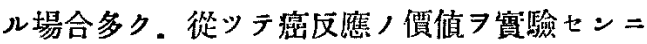
八最モ都合ヨキ領域ニシテ 余ノ行ヒタル例. 160 ，内．診斷確定七ラレタルモ１22 例ノ多 キ二達セリ。之等习分類七ルモノ八第 3 表及ビ 第 4 表ナリ。

第 3 表二於テ明＝惡性隀湯ニ非ザルモノ 27 例 ニシテ其中 10 例二於テ陽性反應ヨ示セリ。 惡性腫瘍ニ非ズシテ癌反雇ヨ示スコトアルハ フックス氏反應ノそナラズ他ノ癌反應/检楂成 績ニモ屡こ見ル所ニシテ.ゼールトSehrt(1936) ノ如キハ最近 10一15\%=ゼールト氏反應ノ陽 性ナルラ見テ，之等八癌素因二由ルモノナルべ シト說ケリ。向ホフックス氏反應习追試セルモ ノシ見ルニキャドネス及方ャルフ(1931)八1C例

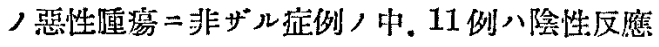
フ見タルモ他， 5 例八陽性反窟习認メ，其中 4 例八胃潰痬ニシテ 1 例ハ腎藏炎ナリキージェド リっカ及ワイヒヘルッ Jedlicka V. u. E. Weichherz (1935) 八检查數 125 例中腎硬化症. 险 禁周圍炎及ビ胃潰滂ノ各 1 例二於テ陽性ナル 見. コワルチーク Kowarzyk(1935) 八225侧

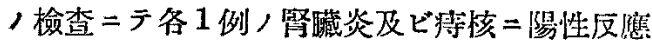

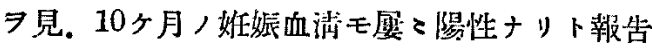
セリ。更二興味アルハ家族二癌ノ多亿癌恐怖症 ，2例二於テ陽性ヨ見タリト云フ。同ジク1935 年ッナクルッェウスキーZalrrzewski ハフック

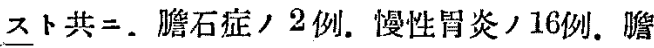

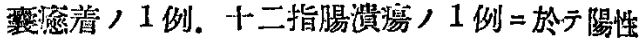
反雇ヨホシタリト報ジ。次イデ1936年】ックス 八次ノ如キ譣說习發表セリ。

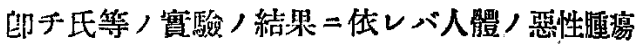
細胞二特有ナル物留入人類昰性腫婸，總テ二於 テ共通ナルモノニテ．其腫虏ノ登生蝪所及ビ如 何ナル肧葉ヨリ由來セルカニハ無關係ナリ。更 二生體ノ分化低キ細胞八之ト近似ナルベキ惡性 腫場細胞トハ少シク性質フ異ニスルノ 共通ナル抗元性 7 有スルモノナリ。其分化低未 細胞八其終局分化 $リ$ 距離ガアレベアル程其生 䯣二對シ異相ニシテ 分化ノ進ム二從ツテ同貿 二濑次近ヅクモノナリ。從ツテ胎細胞八其含ム 物質二依り多クノ異リタル時期 =分ッ事习得儿。 (stofflich unterschiedende Stadien)。此絀x ザル固體發生ノ經過，中=。其含有スル物質， 上カラ其胎細胞が惡性腫湯細胞ノ性質 7 亦 ス籁 園ガ有り そテ所謂「瑟化期」, maligne Zone” ト名ッ゙ケタリ。生理的ノ分化二於テモ此笔圍内 二有儿胎細胞韭 =再生過程= ア・ル細胞八，其特

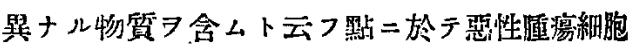

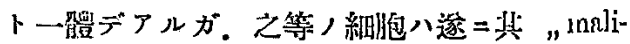
gne Zone" ᄏ越エテ分化シ得ルモノナル二反 シ惡性唓湯細胞ハ其能カラ有七ザルナリ。以上 ，事ヨリ多クノ癌反應二於テ焳娠，或期閒（多 ク八㵎＝近ク）. 及ビ占再生機轉／行ハレ居 几奖患习有スル者二於テ八，瑟性嗹湯力゙存在セ

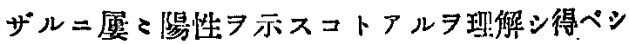

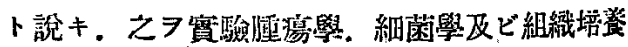
學上ヨリ理諭ヅクタリ。

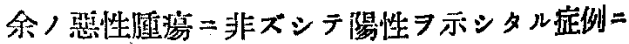
就テ述ペン = 10 例山 1 症例 $=$ 就 $\neq 2$ 回/榆查 アナシタルモ゙ 2 症例アルニヨリ紹局 8 症例。 
就檢查シタル事トナル。其內 2 症例ハ大ナル 㠜「ボリーブ」ニシテ瑟性化ノ疑ヒ有リタル モ组樴的ニハ琶性化

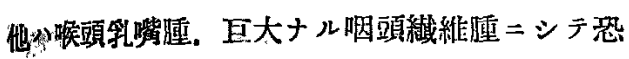

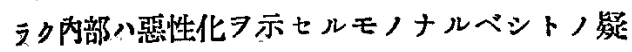

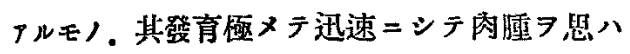

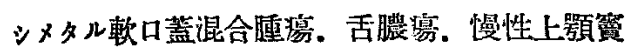
炎, 慢性食道炎，各 1 例=シテ，敦レモ惡性連

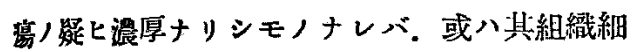
胞中二フ ユ, ス氏，所謂 , maligne Zone" = 屡スペキ細胞习含有シ居タルモノト解スべキ カ: 刃八素因ニョリテ說明セラルべキモノナル ベシ

次二惡性腫場卜確認セラレタルモノ二就キテ見 $ル=$. 其反應型 $/$ 分類八第 4 表二示ス如ク ニ テ. 此丙正常反應 7 示シタルモ, 2 例アリ. 第 7型习示セルモノ6例アリタリ。

之等 7 第 5 表ノ發生部位ヨリ分類サレタルモ， フ見ルニ. 正常反應 $コ$ 示シタル 2 例八食道癌， 1 桝卜唤頭癌全摘出啳11ケ月二頸部淋巴腺 =拇: 指䫓大八轉移 7 來タセル1侧トナリ。第 7 型 示七ルモノ八 6 例中 5 例八治療經過中 $=$ 現 (丙 3 例八同一㭧者 =シテ喉頭癌全摘出後34日. 54日.75日目二检シタルモノナリ).他ノ1例ハ 口蕰癌ニシテ何等治療ブ受ケザルモ. ピルケー

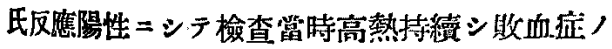

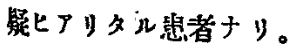

食消澏二於テ屡 フルハ諸家ノ注意セシ所ニシテ．1926年フック

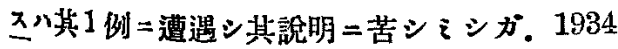
年氏/行ヒタ几檢查總嫩 4360 例中可成り／數

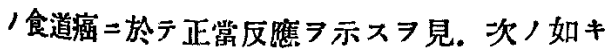
說明フ試にタリ。
印チ正常反隹ヨ示スモノ＝於テハ血液中二抗元 及ビ抗䐺／存在セザルコトラ㲾スモノニシテ。

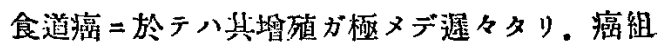
織, 發老不古分ニシテ 轉移モ亦稀ナリ。然モ 尰湯卜血管卜，絬合極メテ少ク，䉆メ二抗元ノ 血液中二移行スル量ガ少ク 癌反應ヨ示ス二至 ラザルナリト。

其後ブランド Brandt E.(1935) 八食道癌八霆

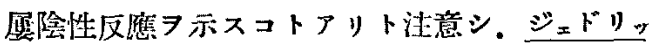
カ及电早へルッ Jedlicka V. u. E. Weichherr.(1935) モ5 例/食道癌中 3 例二陰性反應 ヨ見タリト報告セり。

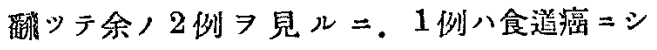
テ 1 例八喉頭癌二テ喉頭全摘出後二於ケル 1 㨐／頸部淋巴腺䡜移 レ居タルフ見レバ. フックス，先退，理由二據 リ說明セラレザルコトナキモ．斯り，如キ說朋

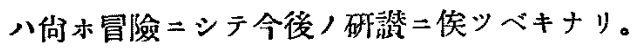
次二第 7 型，反憵が惡性睡獍，洽潦經過中二發. 現ス几機轉二就キテ考察七ン二，第7型ナルモ ，八元來他㷋患，埸合二現ハルべキモ，ニシ テ 正常並二癌「フィプリン」=雤シ異種ナル 他疶患，抗元郎于特殊蛋白翼分解酵㨞ニヨリ兩

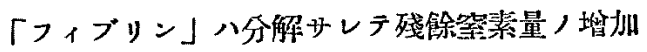
ヨ來タスモノナリ。前述ノ如ク癌治燎經過中= 於テ「フィブリン」二對スル抗元ノ分解作用量 卜抗體，崕制作用量トガ相牛バス几時八癌蓝二 正裳「フィプリン」涯加ノ際。血清ノ々，場合

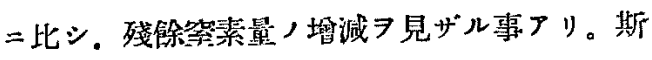

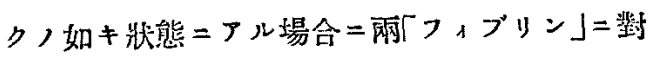
シ異種ナル抗元抗㬐，血液中二位在スル時八 网「フィブリン」八其二破壊セラレテ第 7 型 表シ得ベシト八容易二想像シ得ル所ナリ。1926 


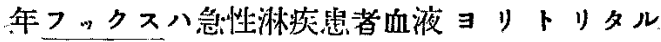
「フィブリン」ハ正常「フィプリン」ト同㨾ノ 態度ヨ示シ 同患者ヨリ探リタル血清モ正常血 清ト同憕ナル態度ヨ示セルラ兒タリ。然ル二淋 菌第一度血行中二入リ。之二依ツテ惹起七うル ル淋毒性關䈱炎，㭧都血液ヨリ得タル「フィブ リン」八，同疾惥々者ヨリ探リタル血清ニヨリ 分解セラレザルモ。正常泣二他/奖患者血清 ショリ破壤サル、当經䮑シ。淋菌ガ血行中二侵 スシテ初メデ血清/特罦化习起スモノニテ. 此 關係八惡性腫演，徽毒。，結㤥。猩紅熟等，場合 卜同㨾ナリト解ケリ。之ト同樣ニシテ，筥木教 授ノ注意セシ如ク．大手術.「ラデゥム」又八 $\lceil レ 」$ 線 $=ヨ ル$ 組織破壇後二其局所二他種細菌 八感染

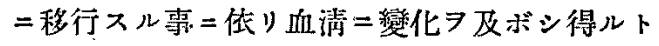
考フレパ，經過中二第 7 型フ表ハスコトモ又可 能ナルベシ。

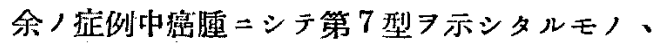
中 1 例八何等治療フ受ケザリシ硬口蓋癌腫二テ 局所八洁穢ナル苔妇以テ蔽レ ピルケー氏反應

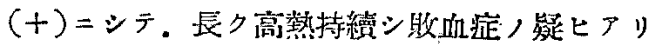
タルモノニテ 結㤥ノ存在セシ篇メカ及八前卜 同樣局所 $コ$ 他種細菌或八其殘骸ノ血行中二侵 入七ル䈍メ二第 7 型ヨ示シタルモノナルベシ。 尚木第 1 及ビ第 7 型䋨合型，治源經過中 $=$ 出現 スル事アルモ同樣二說明七ラルべク 此反應型 ，食道癌ニシテ何等治療可受ケザルモノ =モ山4

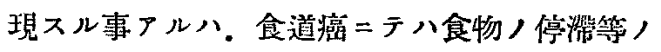

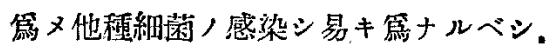

及癌ニシテ何等ノ治療モ受ケズ，ピルケ二氏反

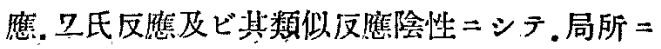
モ縕第感染
1 型及ビ第 7 型ノ結合型ヨ見ルコトアリ。唇谷 川ガ徽量ノフックス氏反應=就キ研㶢セル所二 ヨレパ，旦氏反應及ビ其類似反磨が完斑二陰性

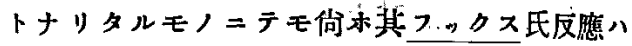

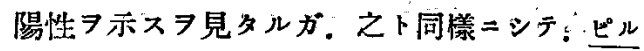

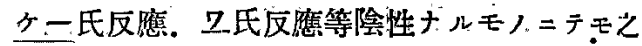
等他種疾㭧八特殊酵素八份木血行中二遗存篇 メ =第 1 型及ビ第 7 型結合型ヨホシ得ルナリ。 又先述シタル所ナルモ婜性腫瘍二テ微毒及゙ゼ結 核等习合併セルモノ=テモ第1 型及ビ第 7 型. 結合型ヨ示サハルモ/却ツテ多キ八..種タナル 反隹型ノ樣々ノ結合ヨ來タスニ由ルモノ犬リ。 他疾患ノ $i$ 場合二就テ見ル二徽毒ハ 3 例共第 7 又八第 9 型 7 示スモ。結核にテハ明カ二紹㤥 病像アルモノ八第 7 型习. ピルケ二氏反應ノ (十)ナルモノ八第 8 型郎于正常反應型ヨ示セル 八注目スベキ點ナルモ症例少キ䉆メ. 其批制八 症例ア重ネテ後日二諭ゼント.ス。

次二反隹型卜预後二就キテ述ベン二. 第 1 型二 シテ特二正常「フィブリン」ヨ强り破壤スル应

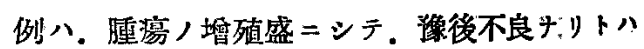
既二安䁚二低り述ベラレタルモ余，症例にテハ 必ズシモ然ラザル八第 1表こ於テ斯グ如キ反 雇型フ示セれモノヨ見レバ明がリ。

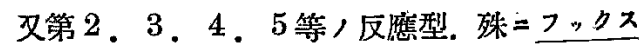
，所謂「冤度反應】型タル第 3 型フ示シタルモ 八八從來フっクス其他八學者二ヨリ臨牃經過良 好ナリト述ベラレタッ。余ノ定例 7 見ル $=$ 第 4 節二述べタル如ク．何等治療习受ケズシラ初メ ヨリ之等/反應型 過良好ナリシモ，8例习見. 又手術後「ラデ 山」又八「レ」線治療中ナルモ\%19 例中 11 例 八經過良好ナルモノナリ。師手以上小是等反應 
型尹示セルモノ八必ズシモ良好ナル經過 $フ$ 取ル モノニ非ズシテ，确後モ又常ニ良ナリトハ云フ ベカラザルタホスモノナリ。殊ニ「ラヂウム」 及ハ「レ」線ノ $i=テ$ 治潦中ノモノニテ是等, 庈應型示シタルモ，14 例中． 6 例八經過良 ナリシモ8例ハ不良ナルラ見タリ。1 191 年キ+ ドネス及ウஃルフが直腸癌ノ1患者二「ラヂウ 山」(量不明) ラ放射七儿後 3 時間ニシテ該患者 血清ノ「フィプリン」破壞作用八全ク止i20日 後二モ該作用ノ戻ラザルラ見タルハ先二述べ 几所ナルモ．之ト同樣比較的僅少ナル「ラヂ 4」量放射モ短時間 =シテ上述ノ如キ影響 $7 及$ ポシ、奖病進行ノ程度二八關セズ. 是等反應型 ヨ示スニ與ツテカアルモノナルニ據リ。第 8 表 二示ス如ク「ラヂゥム」又八「レ」線治療习受 ケタルモノハ、受ケザルモノ=比シ比較的之等

\section{第 五章}

\section{結}

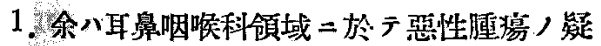
ヒアル患者 160 例二就キフ・クス氏反應ヨ追試 シ. 珠二確實二診断セラレタルモ，122 例二就 丰反倠型，臨师的意我 7 追求七リ。

2. 反應型 99 型二分類シ. 陽性ナ，ル場合 6 型二. 陰性ナル場合 73 型二分チ. 份型，

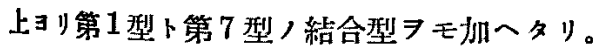
160 侧 $=$ 就キテ見ル = 第 1 型 $31.8 \%$ ，第 2 型 10.6\%。第 3 型 13.1\%。第 4 型 5.6\%。第 5 型 $3.1 \%$ 。第 6 型 $4.4 \%$. 第 7 型 $8.8 \%$ 。第 8 型 11.3 $\%$ ，第 9 型 $3.8 \%$ 。第 1 型卜第 7 型，結合型 7.5 $\%+リ$.

3. 恩性腫瘍，發生部位卜反應型ニ八特別， 關係习認メ得ザルモ. 何レモ第 1 型最モ多ク
ノ反應型タ示スコト多キモ。時二其經過及ビ豫 後ノ不良ナルモノヨ見ルナリ。

最後二適確率

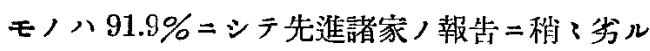
モノナリ。次二確實二診軪セラレタル我ガ科領 域/疾患 122 例，的確率八 90.2 = シテ更二稍に 低下ヲ見ルモ前者 $=$ 比シテ真苴性二富メルモ， ナリ。從來，報告 7 見ル二．多ク八內科的疾患 フ對照トシ．單二臨牀診斷ト一致七シコトノミ 二依り。該反應ノ的確率习諭ジタルモノ多キモ。 吾科領域ニテハ多ク八羅患部 テ、試驗切片アトルコトモ容易ナルラ以テ 澏 反㣹ヨ检查シテ其的確率ヨ決定スルニ八最モ都 合ヨキモノニテ 殊=其中ヨリ確宽二診斷セラ レタル症例 シ以テスレパ. 之ョリ正確ナル的確 率ハナカルベシ。

論

喉頭癌卜鼻腔及ビ鼻咽腔惡性腫湯，數例 $=$ 第 7 型 7 見。食道癌二八第 1 型卜第 7 型卜ノ結合型 比較的多シ。

4 第 3 型郎チフっクス八所謂「免疫反應」 型及ビえ=類似，第 2 。第 4 、第 5 型ヨ示シタ ルモノヨ見ル二經過良好ナルモノモ妸諭存スル モ. 必ズシモ經過緩慢ニシテ免度狀態ニアリト 八思ハレザルモノアリ。

5. 第 7 型八從來他疾患, 場合, $\bar{\varepsilon}=$ 現儿、 モノト考へラレタルモ。惡性腫瘍ノ手術後及ビ 「ラヂウム」及ハ「レ」線治療經過中=屡 ? 現 ハル、モノタ見タリ。其原因八局所ノ細菌感染 ニョリ細菌及八其殘䯚，血行中＝移行スル＝基 クモノト推論ス。 
6. 第 1 型及ビ第 7 型ノ結合型ヨ示スモノ八 必ズシモ他疗㭧习合例セルモノトハ限ラズ。治

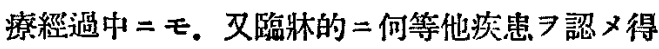
ザルモノ＝モ出現シ．一般二食道癌ニ多シ。之 等ノ理由气第 7 型ノ場合卜同柡ナルカ及ハ潜在 セル他疾患ノ存在二由ルナルベシ。

7 他疾患 $コ$ 合侀セルモノ八種々ナル反隹型 ヨ現シ。必ズシモ第 1 型及ビ第 7 型ノ結合型 7 現サズ，微毒 7 合侀セルモノ八第 1 型多ク．結 核 見タリ。此理由八種々ノ陽性反雇型卜除性反應 型が樣々ナ結合タナスニヨルモノナルペシ。

8.「ラデゥム」及ハ「レ」線放射ヨナシタル モノ八第 2 第 3 . 第 4 . 第 5 等,「免疼反應] 及ハ之二類似スル反憵型比較的多ク．放射 7 受 ケザルモノニテハ第 1 型多シ。

9. 臨牀經過中 3 回以上反雇 $习$ 檢查セシモ， 二就キ、反應型ノ變化 性ナリシモ，癌腫全治シテ反應型ハ全ク正常ト ナリタルモ。再發セル二及ビ，再ビ陽性トナリ タルモノ 2 例アリタリ。初メ陽性反應ヨ示シ治 療經過中 =第 7 型刃八第 1 型及ビ第 7 型ノ結合 型ヨ見タル復. 第 3 型郎チ「免疫反隹」又八其 類似反應型习示セルモ/ 3 例 リ绝疫反應型及八其類似型ヨ示シ其後 2 回トモ

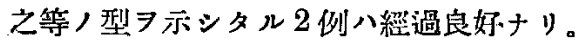

10. 癌ニシテ正常反應郎チ第 8 型フ示シタル モノハ食道癌ノ1 例. 及ビ喉頭癌ニシテ喉頭全

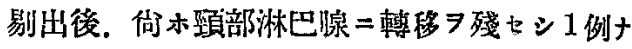
リ。

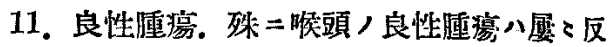
㗹陽性ナルコトアリ。

12. 反應型ニヨリ淮後 7 制定シ得ル十否ヤ;

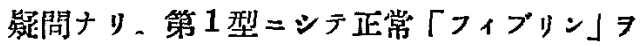
强ク破壞スルモノ必ズシモ不良ナラズ。從來考 ヘラレタル如ク第 3 型郎チ「免疫反應」型及ビ 之=類似，第 2 、第 4 、第 5 等/反㮣型习示七 ルモノ必ズシモ經過良ナリトハ限ラズ，等ノ 反應型ヨ示シタルモノニテ經過良好ナリシモノ 八約其半㗪ニシテ 殊ニ「ラヂム」区「レ」 線ノ $\mathfrak{i}=\exists$ ル治潦經過中二之等, 反應型习示七 ルモノニテ經過良好ナリト認ムルモノ八其牛數 以下ナり。

13. 的確椊 7 定メル ル 當り第 7 型ニシラ瑟性 腄㾂ノ治療經過中二現レタルモノ八陽性卜判定 シ. 其他 7 陰坐卜判定セり。的確率八 160 例中 單二臨牀診断ト一政セシモノヨ以テスレバ 91.9

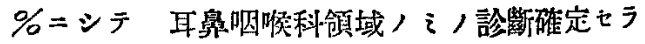
レタルモノ 122 例=就キテ見ル $=90.2 \%$ ニテ 從來ノ報告二稍 $こ$ 劣ルモ. 後者八其畺實性，二於 テ從來ノ報告二儦ルモノナリ。

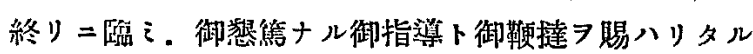

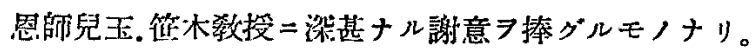




\section{主 要 文 献}

1) Abderhadien, E.: Abwehrferment, 1914. 2) Abderhaiden, E. u. s. Buaze: Fermentforschung, Jg. 13, 137, 1933. 3) Auriu, Kowarzyk und Fuehs: $Z$. f. Immunitätsforschung. 80, 420, 1933. 4) Brmat, E.: Klin. Wschr. Jg. 14, 1935. 5) Erandt, E.: Z. f. Krebsforsthung, Bd. $43,370,1936$. 6) Bing: $Z$. f. Krebsforschung. Bd. 40, 22, 1984. 7) Calness, B. H. E. u. C. A. I. Wolf: Biochem. Z. Bd. 238, 287, 1931. 8) Cadness, B. H. E. u. C. a. I. Wolf: Fermentforschung. Jg. 13, 1, 1933. 9) Caspary: Z. f. Immunitätsforschung. 82 , 506. 10) Caspary, H.: Klin. Wschr. Jg. 13, 668, 1934. 11) Chrometnka, Fr. u. P. Goullebe: $Z$. f. die gesamte exper. Medizin. Bd. 86 . 436, 1938. 12) Dastre: Arch. de Physiolog. 6, 464, 1892. 13) Ehrlich: $Z$ : f. Krebsforschung. Bd. 5, 59, 1907. 14) Falkenhausen, I. v.: Deut. med. Wschr. 58. Jg. Nr. 9. 329 , 1982. 15) Falkenhutusen, M. v. u. F. $\boldsymbol{x}$. Fuchs: Z. f. Krebsforsihung. Bd. 37, 362, 1982. 16) Frenud, F.: Wiener Klinische Wsahr. Nr. 12, 130, 1921. 17) Freund, E. u. G. Kaminer: Wiener Klinische Wschr. Nr. 10, 51, Nr. 34, 1910. 18) Freund, E. u. G. Kaminer: Biochem. Z. Bd. 26, 311, 1910. 19) Freund, E. u. G. Kaminer: Biochem. Z. Bd. 46, 470, 1912. 20) Freand, E. a. G. Kaminer: Biochem. $Z$. Bd. 149, 245, 1924. 21) Fuchs, H. J.: Biochem. Z. Bd. 170, 76, 1926. 22) Fuchs, H. J.: Biochem. Z. Bd. 175, 185, 1926. 23) Fuehs, H. J.: Biochem. Z. Bd. 176, 32, 1926. 24) Fuelis, 1C. J. u. M. V. Falkenhansen: Biochem. Z. 176, 92, 1926. 25) Fuchs, 1. J.: Biochem. Z. Bd. 178, 152, 1926. 26) Fuchs, H. J. u. M. V. Falkenhausen: Biochem. $Z$. Bd. 178, 155, 1926. 27) Fuehs, I. J. u. M. V. Falkenhausen: Biochem. Z. Bd. 237, 37, 1931 . 28) Faehs, H. J.: Med. Klinik. Jg. 2t, Nr. 9, 337, 1928. 29) Fuehs; w. J.: Z. f. Immunitāts. forschung. u. experim. Therap. Bd. 57, 320, 1928. 30) Fuehs, 1r. J.: Z. f. Immunitätsforschung. u. experim. Ther.p. Bd. 77, 343, 1932. 31) Fachs, 11. J.: Z. f. Krebsforschung. Bd. 37, 367, 1932. 32) Fnchs, h. J. u. M. v. Fabkenhausen: Biochem. Z. Bd. 245, 304, 1932. 33) Fuchs, M. J.: Münch. med. Wschr. 79, Jg. Nr. 43, 1711, 1932. 34) Fuehs. F. J. u. w. F. Devrient: D. 1 . W. Jg. 58, Nr. 42, 1932. 35) Fuchs, H. J. u. M. v. Fulkenhnuseu: Z. f. die gesamte exper. Medizin. Bd. 81, 169, 1932. 36) Fuylus: Z. f. Immunitätsforschung. 80, 233, 1933. 37) Fuchs u. Howarzyk: Z. f. Immunitãtsforschung. $80,375,1933$. 38) Fuehs, 11. J.: Klinische W. Jg. 13, Nr. 8, 1934. 39) Fachs, er. J,: Z. f. Krebsforschung. Bd. 44,384, 1936. 40)富士山：新血漓學及ビ演藥法.

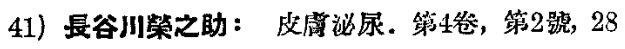
頁, 昭和11年. 42) 長谷川榮之助：皮底泌尿，第

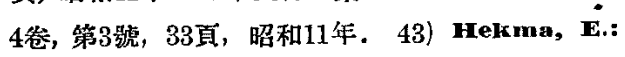
Biochem. Z. Bd. 62, 161, 1914. 44) Hekma, E.: Biochem. Z. Bd. $63,184,204,1914.45$ ) Hexzfela, w. u. K. Kuinger: Biochem. $Z$. Bd. 83, 228, 1917. 46) 引地與五郎, 上田競：日生

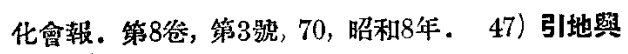
五郎, 上田靿：九州整會点，第36回，212, 昭和9 年. 48) 引地與五郎: 東西䂑學. 第4第11號, 42, 昭和 12年. 49) Hiller, A. u. D. D. V. S1yke: J. of biolog. Chem. Bd. 53, 253, 1922.

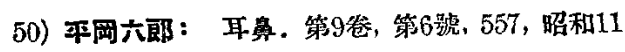
年. 51) 平网六郎, 柴田元之助：耳算. 第10卷, 第5啒，457, 昭和12年. 52）平岡六郎, 柴田元之

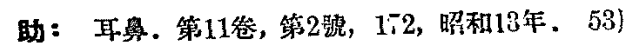
Karka, v.: Z. f. Krebsforschung. Bd. 4L, 188, 1935. 54) Kafka, V.: Z. f. Krebsforschung. Bd. $41,370,1935$. 55) Kafka, v.: Z. f. Kretsforschung. Bd. 42, 241, 1935 . 56) Kartas, v.: W. m. Wschr. Jg. 86, Nr. 44, 1213, 1936. 57) 植內三郎：生化學. 58) 川島霞一, 小久保佐一, 有吉之吉, 山崎信四郎, 花島宗泰：日消化機會誌。 
第34卷，第5虢，321，昭和10年．59）兒玉桂三，引 地與五郎：日耳鼻全萻. 第1兊, 4, 545頁, 昭和9年. 60）兒玉桂三：筫地醫家. 第 12 卷, 第3 3 號, 221 頁. 昭和10年. 61) Kowarzyk, H.: Z. f. Krebsforschung. Bd. 41, 162, 1985. 62) Kowarzyk: Z. f. Krebsforschung. Bd. 63) Kralns, F.: Aerztl. Fortbidung. Nr. 19,62t, 1931. 64) Lehmann-Faeins, H.: $Z$. Immunitätforschg. Bd. 48, 397, 1926, Bd. 51, 464, 1928. 3d. 67, 373, 1930. Frank. Z. path. Bd. 41, 521, 1921. 65) Jothammer, R. u. A. Pistofelis: $Z$. f. Krebsforschung. Hd. 45, 105, 1937. 66) Lotthnmer, R. u. Rosembohn: $Z$. f. Krebsforschung. Bd. 45, 28, 1937. 67) Inmsden, Th.: Amer. J. Canc. 15, 563, 1931. 68) 觜見 省吾, 引地與 五副, 早田㬶：皮泌尿. 第2卷, 第2 裉，165真，昭和9年，69）中川猃, 高㭅年雄, 小川

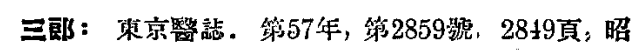
和8年. 70) Neuberg, C.: Bioch. Z. Bd. 26, 344, 1910. 71) Neuberg, c.: Oppenheimer's Handbuch der 13iochemie 2. II. 377, 1909, Bd: 4, 441, 1925. 72) Rona, P.: Fermentmethoden. 1931. 73) Rosendach: Biochem. Z. Bd. 129, 106, 1923. 74) Rosenmann, M.: Biochem. Z. Bd. 112, 98, 1920. 75) Ramon, G.: C. «. Soc. 13iol. Paris. 86, 661, 1922, 89, 2, 1923. Ann. Inst.

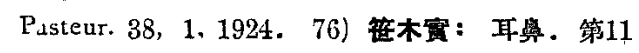

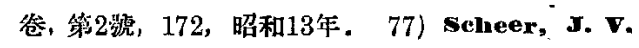
D.: $J$. of Immunology. $18,17,1930.78)$ schittenhelm, A. u. Hersg. .. 'Theodor Brugseh: Z. f. Krebsforschung. 13d. 27, Rof. 57, 1928. 79)

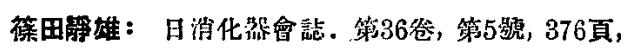

炤和12年. 80) Stephan, R. u. F. Wohl: Z. f. die gesamte exper. Medizin. Bd. 2£, 391, 1921. 81) Stephan, R.: $Z$. f. die gesamte exper.

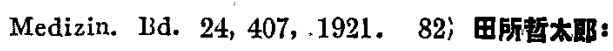

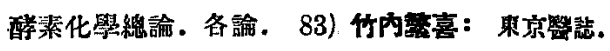
筷3031號，1304頁，昭和12年. 81) Thiensen, A.: Biochem. Z. Bd: 140, 457, 1924. 85) 上山武男:

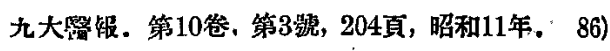
上山武男：日婦會誌，第32忩，第4號，526頁，昭 和12年. 87) Van S1yke, D. D. u. A. Hiller: J. of biolog. Chem. No. 2, V. 102, 499, 1933. 88) Waldschmitz-Leitz, E. u. A. Schidfmer: Naturwissensshafen. 18, 280, 1930. 89) Wright, M. w. M. Winipred and c. G. I. Wolr: C.

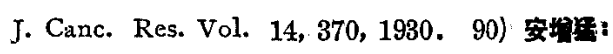

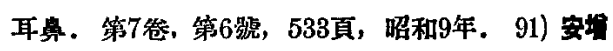
猛：耳悬. 第7参, 第9號，818頁, 昭和9年. 92) 安倜猛: 耳兽. 第8卷, 第4號，373頁, 昭和10年.

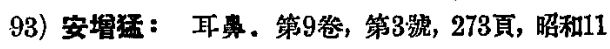

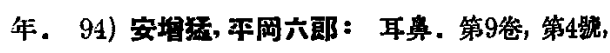
380 頁，昭和11年．95）安牾猛：耳第9卷，第 5號，438頁，昭和11年，96) Yokota, k.: Biochem. Z. Bd. 232, 58, 1931. 97) 吉川传二: 北 海醫誌。第14年，第6號. 1392頁, 昭和11年.98)

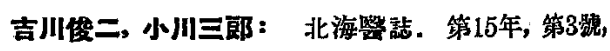
839頁，昭和12年．99）吉川传二：北海頤誌. 第 15年，第3 號，768頁，昭和12年，100）吉住好夫:

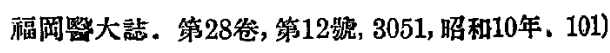
吉住好夫：日病理會誌、第25卷; 709, 昭和10年. 102) Zakrzewski, z. u. H. J. Fuchs: Klinisehe, W.: Jg. 14, Nr. 4, 127, 1935. 